\title{
Marine Bacterial Secondary Metabolites: A Treasure House for Structurally Unique and Effective Antimicrobial Compounds
}

\author{
Ramanathan Srinivasan ${ }^{1,2, *,+} \mathbb{D}$, Arunachalam Kannappan ${ }^{3,+} \mathbb{D}$, Chunlei Shi ${ }^{3}$ and Xiangmin Lin ${ }^{1,2,4, *} \mathbb{D}$ \\ 1 Fujian Provincial Key Laboratory of Agroecological Processing and Safety Monitoring, School of Life Sciences, \\ Fujian Agriculture and Forestry University, Fuzhou 350002, China \\ 2 Key Laboratory of Crop Ecology and Molecular Physiology, Fujian Agriculture and Forestry University, \\ Fuzhou 350002, China \\ 3 State Key Laboratory of Microbial Metabolism, MOST-USDA Joint Research Center for Food Safety, \\ School of Agriculture and Biology, Shanghai Jiao Tong University, Shanghai 200240, China; \\ kannanacmdu@sjtu.edu.cn (A.K.); clshi@sjtu.edu.cn (C.S.) \\ 4 Key Laboratory of Marine Biotechnology of Fujian Province, Institute of Oceanology, \\ Fujian Agriculture and Forestry University, Fuzhou 350002, China \\ * Correspondence: vasanbiotech@gmail.com (R.S.); xiangmin@fafu.edu.cn (X.L.) \\ + The authors contributed equally to this work.
}

check for updates

Citation: Srinivasan, R.; Kannappan, A.; Shi, C.; Lin, X. Marine Bacterial Secondary Metabolites: A Treasure House for Structurally Unique and Effective Antimicrobial Compounds. Mar. Drugs 2021, 19, 530. https:// doi.org/10.3390/md19100530

Academic Editor: Ronald O. Garcia

Received: 18 August 2021

Accepted: 15 September 2021

Published: 23 September 2021

Publisher's Note: MDPI stays neutral with regard to jurisdictional claims in published maps and institutional affiliations.

Copyright: (c) 2021 by the authors. Licensee MDPI, Basel, Switzerland. This article is an open access article distributed under the terms and conditions of the Creative Commons Attribution (CC BY) license (https:// creativecommons.org/licenses/by/ $4.0 /)$.

\begin{abstract}
The prevalence of antimicrobial resistance reduces the effectiveness of antimicrobial drugs in preventing and treating infectious diseases caused by pathogenic organisms, such as bacteria, fungi, and viruses. Because of the burgeoning growth of microbes with antimicrobial-resistant traits, there is a dire need to identify and develop novel and effective antimicrobial agents to treat infections from antimicrobial-resistant strains. The marine environment is rich in ecological biodiversity and can be regarded as an untapped resource for prospecting novel bioactive compounds. Therefore, exploring the marine environment for antimicrobial agents plays a significant role in drug development and biomedical research. Several earlier scientific investigations have proven that bacterial diversity in the marine environment represents an emerging source of structurally unique and novel antimicrobial agents. There are several reports on marine bacterial secondary metabolites, and many are pharmacologically significant and have enormous promise for developing effective antimicrobial drugs to combat microbial infections in drug-resistant pathogens. In this review, we attempt to summarize published articles from the last twenty-five years (1996-2020) on antimicrobial secondary metabolites from marine bacteria evolved in marine environments, such as marine sediment, water, fauna, and flora.
\end{abstract}

Keywords: antibacterial; antifungal; antimicrobial; antiviral; marine bacteria; marine fauna; marine flora; marine sediments; marine water; secondary metabolites

\section{Introduction}

Bacteria are ubiquitous, and they are vital for the preservation of the ecosystem in which we live. Only a small percentage of bacteria are pathogenic. However, the infections caused by pathogenic bacteria significantly affect public health [1,2]. Bacterial infections are often more superficially controlled than fungal and viral infections because of the presence of an antibacterial drugs arsenal with growth inhibitory activity. However, the rapid development of bacterial resistance to antimicrobials is a pressing issue that surpasses the devastating effects of fungal and viral infections $[1,3]$. The phenomenon of resistance is not equivalently spread across all bacterial species. However, the Infectious Disease Society of America (IDSA) has recognized six bacterial species as highly dangerous owing to their possible multidrug resistance mechanisms and pathogenicity [4]. Enterococcus faecium, Staphylococcus aureus, Klebsiella pneumoniae, Acinetobacter baumannii, Pseudomonas aeruginosa, and Enterobacter sp. are referred to as ESKAPE pathogens. These ESKAPE 
pathogens are the frequent causes of severe or life-threatening infections, particularly in immunocompromised individuals, critically sick individuals, and children [5-7].

Fungal pathogens, such as Candida sp. and Aspergillus sp., may cause life-threatening infections that lead to illness, and possibly death [8]. For example, Candida albicans, a frequent colonizer of gut mucosal surfaces, are among the top five infectious agents responsible for sepsis [9]. Furthermore, invasive candidiasis is the most prevalent fungal infection among hospitalized patients, with a mortality rate of $40 \%$ [10]. Similarly, Aspergillus fumigates has emerged as a key pathogen in cancer patients. When healthy people inhale conidia of A. fumigates, the host's innate immunity is adequate to eliminate the organism without forming antibody or cell-mediated acquired immunity [11]. On the other hand, A. fumigates in immunocompromised individuals increases the risk of developing severe invasive illnesses with mortality rates ranging from 40 to $90 \%$ [12].

Viruses are very contagious and cause infections in humans. Due to horizontal transmission, we have seen many viral pandemics. Such pandemics have culminated in health and economic crises. Since December 2019, the entire world has been in the grips of another pandemic viral outbreak. This time, it is severe acute respiratory syndrome coronavirus 2 that is the causative agent of the pandemic. Since then, the viral pandemic has claimed millions of lives and wreaked havoc on the global economy [13,14]. Additionally, humankind is currently still battling a past pandemic caused by the human immunodeficiency virus. The acquired immunodeficiency syndrome (HIV/AIDS) outbreak has infected 37 million individuals globally [15].

The arsenal of chemical compounds used to treat human microbial infections was considered adequate after discovering most of the antimicrobial classes from the 1940s to 1960s, the so-called "Golden Age" of antimicrobial research [16]. However, the rapid development of antimicrobial resistance in microorganisms quickly contradicted the premise of antibiotics. Antimicrobials exert selection pressure on microorganisms, resulting in random chromosomal changes that make the microbes more amenable to living in the environment with antimicrobials, disinfectants, and chemical compounds [17-20]. The genetic material that encodes for such amenability is quickly replicated and disseminated [21]. In addition, the excessive and inappropriate usage of antimicrobial agents also drastically accelerates the development of drug resistance [22,23]. As a result, pathogenic microorganisms have emerged and reached epidemic and pandemic levels. Antimicrobial-resistant pathogenic microorganisms are classified as a threat to human health by the World Health Organization (WHO), and the Centers for Disease Control and Prevention (CDC) [24,25]. It is also estimated that antimicrobial resistance could cause 10 million deaths per year by 2050, resulting in a global economic loss of up to $\$ 100$ trillion [26].

Over the past two decades, the number of new antimicrobials on the market has decreased. However, harmful microorganisms have developed a high resistance rate, implying that existing antimicrobials are no longer effective [27-29]. As a result, increased efforts toward developing and commercializing new antimicrobial agents are urgently needed [30]. While considerable progress has been achieved in the chemical synthesis and engineering biosynthesis of antimicrobial agents, nature remains the richest and most versatile source for discovering novel antimicrobial agents [31]. To find effective compounds with unique antimicrobial characteristics, researchers from all around the globe are searching meticulously for novel sources in a variety of natural environments. After pointing out the fundamental health risks faced by humankind due to pathogenic organisms, this review explores the contribution of marine bacterial-derived natural products in the fight against microbial infections.

\section{The Marine Environment: A Goldmine for Natural Product Research}

Oceans encompass 70\% of the Earth's surface, and their phylogenetic diversity is considerably greater than that of the terrestrial environment because of the differences in location, temperature, and salinity $[32,33]$. The ocean is home to an estimated $50-80 \%$ of all life on Earth [34]. The oceans are a unique and abundant supply of bioactive compounds 
for the pharmaceutical industries owing to the enormous genetic and ecological diversity of marine entities [35]. Over the last 50 years, more than 20,000 natural compounds have been identified in the marine environment [36]. This complex ecosystem has been identified in various marine entities, including marine plants, animals, their associated microbes, and the microorganisms derived from marine sediment and marine water [9,37-41]. Most conventional secondary metabolites have been discovered in terrestrial flora and fauna and their associated microorganisms [42-47]. These secondary metabolites have previously been found and reported to have effective therapeutic and antimicrobial capabilities [48-52]. However, the rediscovery of known chemical compounds has hampered novel antimicrobials in the terrestrial environment for the treatment of microbial infections [53]. Recently, significant attention has been directed toward marine metabolites, which may provide the key to developing effective therapeutic agents against microbial pathogens, while substantial research on new antimicrobials has been conducted in the terrestrial environment [54]. The natural products obtained from marine environments have various structural characteristics and vary from those found in terrestrial environments [55].

Marine organisms have provided essential components that have shown their potential for use in industrial development as agrochemicals, as well as in cosmetics, fine chemicals, nutritional supplements, and as therapeutic agents for treating several illnesses [56]. Over the last 25 years, the discipline of marine drug discovery has expanded with over 35,000 research articles on natural chemical compounds derived from marine origins [57]. This is also shown by the rapid discovery of new secondary metabolites and a large number of marine-derived therapeutic candidates in clinical trials or awaiting approval $[58,59]$. Thus, the marine environment is expected to provide the pharmaceutical sector with the next generation of antimicrobial agents $[60,61]$.

\section{Secondary Metabolites from Marine Bacteria: A Treasure House of Natural Bioactives}

Microorganisms are more suited to the large-scale synthesis of bioactive compounds, as they overcome the difficulties associated with acquiring drugs via massive harvesting [62]. Secondary metabolites produced by microorganisms, such as bacteria and fungi, may have effective bioactivity against other microorganisms or the specific physiological conditions of a diseased body. Since the first antibiotic penicillin discovery in the 1920s, it has been assumed that secondary metabolites from microorganisms constitute the primary source of novel secondary metabolites with antimicrobial activities [63]. Microorganisms, particularly bacteria, are considered a fascinating source of structurally diverse and effective bioactive compounds $[54,64]$. Bacteria from marine water, sediment, and marine organisms can produce a wide range of novel therapeutic compounds with a broad range of applications [65]. The associated marine bacteria use nutrients (e.g., carbon) generated by their host to defend themselves against harmful entities in the environment by secreting active biological chemicals [66]. Furthermore, this selection revealed that, compared to other surface-dwelling bacteria, associated bacterial communities might produce novel antimicrobials to maintain their host position. As a result, it has been shown that these bacteria generate various bioactive compounds [23]. Many bioactive compounds were identified from marine bacteria, such as antibacterial, antiviral, antifungal, antiquorum-sensing, and anticancer substances [67-69]. Earlier evidence suggests that bacteria associated with marine organisms generate secondary metabolites attributed to the hosts [65]. The production of such secondary metabolites by marine bacteria opens up new avenues for developing novel natural compounds. Furthermore, marine bacteria are proving to be an exciting source for the development of novel therapeutic agents. For instance, if adequately screened and scrutinized, marine bacteria might provide us with the antimicrobials necessary to fight drug-resistant pathogens for the next 100 years [30].

\section{Antimicrobial Production by Different Phyla of Marine Bacteria}

Marine microbes produce about 23,000 bioactive secondary metabolites, according to estimates. Among the different marine microorganisms, the secondary metabolites 
produced by marine bacteria have many biological activities, including antimicrobial potential [70]. The six phyla of marine bacteria (Actinobacteria, Bacteroidetes, Cyanobacteria, Firmicutes, Planctomycetes, and Proteobacteria) seem to be the frequent primary sources of antimicrobial compounds among the various phyla investigated so far [71-75]. Our literature survey shows the presence of around 834, 53, 148, 1214, 3, and 1565 scholarly articles published between the years 1996-2020 related to antimicrobial activity in the PubMed database with the keywords: "marine Actinobacteria", "marine Bacteroidetes", "marine Cyanobacteria", "marine Firmicutes", "marine Planctomycetes", and "marine Proteobacteria", respectively (Figure 1A). The main phyla linked with antimicrobial activity are Actinobacteria, Firmicutes, and Proteobacteria, which account for more than $93 \%$ of the scholarly articles addressed in the last twenty-five years (Figure 1B).

(A)

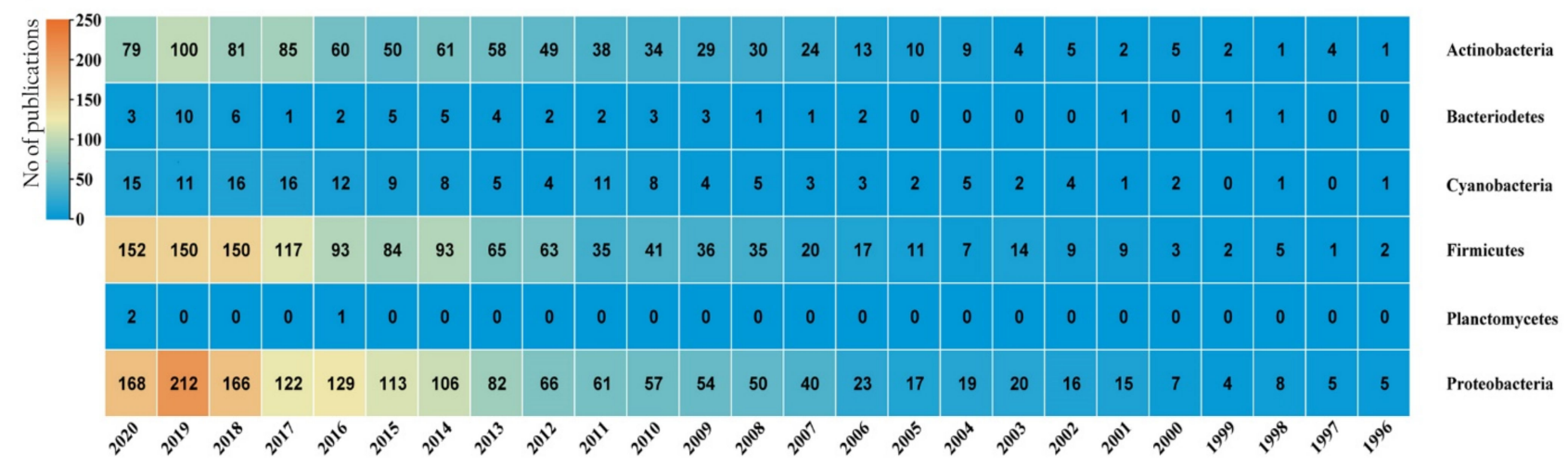

(B)

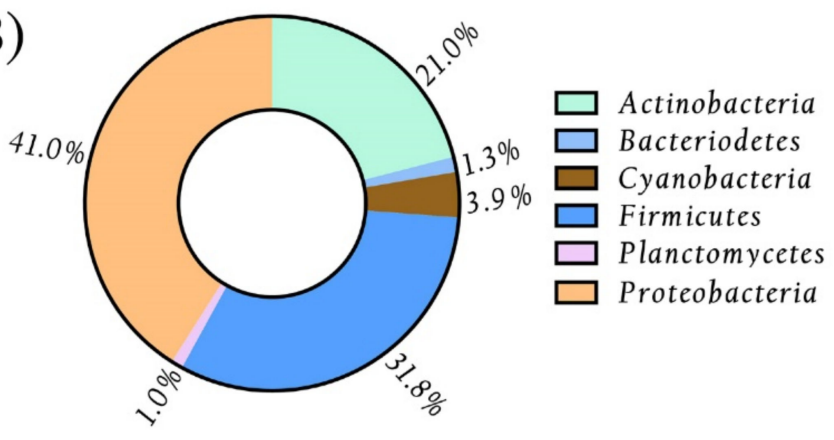

Figure 1. Antimicrobial activity was reported from the main marine bacterial phyla. (A) Categorization of articles published between the years 1996-2020, according to bacterial phylum, using the keywords "marine phylum" ['marine Actinobacteria', 'marine Bacteriodetes', 'marine Cyanobacteria', 'marine Firmicutes', 'marine Planctomycetes', and 'marine Proteobacteria'], and "antimicrobial activity". Source: PubMed database (https:// pubmed.ncbi.nlm.nih.gov/, accessed on 25 July 2021). (B) The pie chart shows the percentage of scholarly articles related to major marine bacterial phyla that have been published for their antimicrobial potentials in the last twenty-five-year study period.

\subsection{Antimicrobial Potential of Marine Actinobacteria}

The phylum Actinobacteria is Gram-positive bacteria known for their pioneering efforts to synthesize a diverse array of valuable secondary metabolites. Actinobacteria are abundantly present in marine environments, where they serve an essential ecological role in recycling refractory biomaterials and producing novel bioactive compounds with pharmaceutical applications [76]. The abundance and distribution of Actinobacteria may vary among the diverse marine organisms. Most actinobacterial species are frequently isolated from bottom sediments, seashores, coastal waters, mollusks, fish, seaweeds, sponges, and mangroves [77-79]. According to studies employing culture-dependent and independent molecular methods, abundant novel actinobacterial communities are associated with sponges [80-82]. Further, the phylum Actinobacteria are represented by one-sixth 
of the sponge-associated bacterial sequences in public databases, suggesting that Actinobacteria are a significant phylum among sponge-associated bacteria [83]. Although they are commonly found in bottom sediments, they rarely account for more than $10 \%$ of the live microflora.

Marine environments are home to many actinobacterial taxa, including Micromonospora, Nocardiopsis, Nocardia, Plantactinospora, Solwaraspora, Saccharomonospora, Streptomyces, and Salinispora [84]. Among these, Streptomyces is a widespread actinobacterial genus found in marine environments. This actinobacterial genus shows a wide range of physiological and metabolic characteristics, including the ability to produce a wide array of extracellular enzymes and secondary metabolites, many of which are exploited by the pharmaceutical industry [85]. Recently, Contreras-Castro et al. isolated 75 Actinobacteria from marine sediment in Punta Arena de La Ventana, Mexico. A total of seventy-one isolates were confirmed belonging to the genus Salinispora by 16S rRNA gene identification and multilocus sequence analysis. They subsequently evaluated the antibacterial potential of supernatants from several Salinispora strains, revealing that supernatants from ten Salinispora strains had excellent growth inhibition activity against ESKAPE pathogens [86]. Similarly, in another study, a total of 148 Actinobacteria were isolated from Diu Island's intertidal sediments in the Arabian Sea [79]. All the isolates were categorized within actinobacterial taxa: Glycomycetales, Micromonospora, Nocardia, Nocardiopsis, Pseudonocardiales, and Streptomyces. Among the 148 isolates, 62 different actinobacterial isolates were subsequently tested for their antibacterial activity against Bacillus subtilis, Escherichia coli, K. pneumonia, and S. aureus. Out of these, 23 isolates were positive for one or more of the tested bacterial pathogens. Yücel and Yamaç revealed the antibacterial efficacy of Streptomyces sp. 1492 against drug-resistant bacterial pathogens, such as E. faecium, S. aureus, and A. baumannii [87]. Chlorocatechelins are novel siderophores with chlorinated catecholate complexes and an acylguanidine structure [88]. Chlorocatechelin A (Figure 2, Compound 1) extracted from Streptomyces sp. inhibited the growth of a wide range of bacterial and fungal pathogens. The new Streptomyces sp. MUSC 135T strain was isolated from mangrove forest sediment on Peninsular Malaysia's east coast. It can produce the broad-spectrum antibiotic molecule bacitracin A (Figure 2, Compound 2), effective against $S$. aureus ATCC BAA-44 [89,90]. Novel bioactive compounds, such as indole-3-lactic acid (Figure 2, Compound 3) and phenylacetic acid (Figure 2, Compound 4), were isolated from the fermentation broth of Streptomyces CTF9. In prescreening studies, the bioactive compounds containing Streptomyces extract exhibited strong antifungal activity against C. albicans and Mucor miehei [91].<smiles>CC(=O)NCCCCC[C@H](NC(=O)[C@H](CCCCNC(N)=NC(=O)c1ccc(Cl)c(O)c1O)NC(=O)c1ccc(Cl)c(O)c1O)C(=O)O</smiles>

(1) Chlorocatechelin $\mathrm{A}^{\mathrm{OH}}$<smiles>O=C(O)[C@H](O)Cc1c[nH]c2ccccc12</smiles>

(3) Indole-3-lactic acid

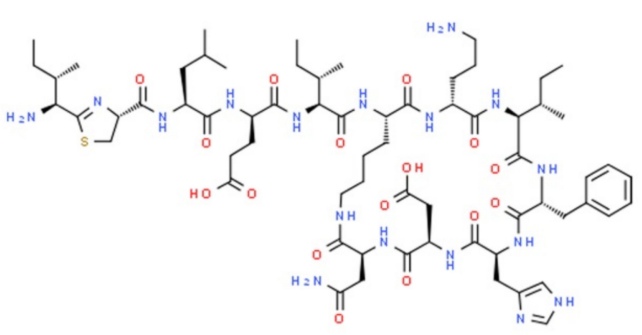

(2) Bacitracin A<smiles>O=C(O)Cc1ccccc1</smiles>

(4) Phenylacetic acid

Figure 2. Structural representation of antimicrobial compounds 1-4 derived from marine Actinobacteria. 


\subsection{Antimicrobial Potential of Marine Bacteroidetes}

Bacteroidetes is the third most common phylum in the oceans, behind Proteobacteria and Cyanobacteria [92]. Bacteroidia, Cytophaga, Flavobacteria, and Sphingobacteria are the four major classes of the Bacteroidetes phylum. Bacteroidetes is classified into major Gram-negative, rod-shaped, and non-spore-forming bacteria that can live in aerobic and anaerobic environments [93]. Groups of bacteria related to phylum Bacteroidetes may be found in abiotic environments, such as marine sediments, marine seawater, and soil, and biotic habitats, such as animal skin and intestines [94].

A recent comparative genomic analysis revealed abundant Flavobacterium in the marine environment, often associated with fish, marine invertebrates, and algae. According to their genome mining data, the bacteria belong to the genus Flavobacterium have a broad secondary metabolite biosynthesis arsenal, with a high frequency of gene cluster-coding pathways for the production of several pharmacological activities, including antimicrobial ones. Further, they have done antimicrobial phenotypic assays to confirm their genomederived data [95]. The antimicrobial substances producing marine bacteria belonging to the genus Flavobacterium were isolated from marine invertebrate samples collected from Ancon Bay, Lima, Peru. The bacterial isolates from the genus Flavobacterium exhibited intense antibacterial activity against many human bacterial pathogens [96]. The biotechnological potential of microorganism-derived glucose dehydrogenase enzymes has attracted much interest because of their antimicrobial potential in various industrial applications [97]. The membrane fraction of the marine bacterium Cytophaga marinoflava IFO 14170 yielded a new glucose dehydrogenase [98].

\subsection{Antimicrobial Potential of Marine Cyanobacteria}

Cyanobacteria are the only bacterial phylum that derive their energy from the process of photosynthesis. Further, it is the only photosynthetic prokaryote group capable of producing oxygen and absorbing $\mathrm{CO}_{2}$ [99]. The marine Cyanobacteria are a powerful nonconventional source of bioactive compounds with a bright and hopeful future in drug development for treating various diseases [100]. Richard E. Moore's groundbreaking research at the University of Hawaii from the 1970s to the early 2000s shows marine Cyanobacteria to be a potent source of secondary metabolites [101]. Many of these secondary metabolites are distinctively combined with the structural characteristics of peptides and lipids before being further functionalized with atypical oxidations, halogenations, and methylations [102]. Moreover, most of these secondary metabolites are nitrogen-based compounds produced by multimodular nonribosomal polypeptide [100]. The secondary metabolites of marine cyanobacteria have been previously well-reported for their pharmacological activities, such as antibacterial, antiviral, antifungal, anticancer, and antiplasmodium properties [103].

The secondary metabolites ambiguine- $\mathrm{K}$ and $\mathrm{M}$ isonitrile (Figure 3, Compounds 5 and 6), isolated from the marine cyanobacterium Fischerella ambigua (UTEX 1903), have exhibited intense antibacterial activity against Mycobacterium tuberculosis with MIC values of 6.6 and $7.5 \mu \mathrm{M}$, respectively [104]. The novel alkylphenols, anaephenes A-C, were isolated from the cyanobacterium Hormoscilla sp. It showed moderate growth inhibition against S. aureus [105]. At the concentrations of $22,6.1$, and $22 \mu \mathrm{g} / \mathrm{mL}$, respectively, anaephenes A, B, and C inhibited the complete visible growth of the S. aureus. It seems that there are just a few antiviral drugs that were isolated from marine bacteria when compared to the antibacterial and antifungal drugs. Among them, a maximum of the reported antiviral compounds was derived from marine Cyanobacteria. Glycolipids are found in prokaryotic and eukaryotic photosynthetic organisms, where they are connected with thylakoid membranes. Glycolipids are also found in the heterocystous cell walls of Cyanobacteria [106]. Glycolipids have been found to have distinct antiviral activity in many investigations $[107,108]$. Gustafson et al. tested extracts of marine Cyanobacteria (Phormidium tenue and Yngbya lagerheimii) for HIV-1 inhibition using a tetrazolium-based microculture. As a result, sulfonic acid-containing glycolipids were identified as a novel 
family of HIV-1-inhibiting agents [109]. The novel acylated diglycolipids, and diacylated sulfoglycolipids, were derived from the Cyanobacterium Oscillatoria raoi and Scytonema sp., respectively. Both of these glycolipids inhibited HIV-1 reverse transcriptase enzymatic activity at a final concentration of $10 \mu \mathrm{M}$ [106]. The sulfoquinovosylpranosyl lipids from lipophilic extracts of Cyanobacteria were responsible for the strong in vitro suppression of HIV-1 enzymatic activity. With a half-maximal inhibitory concentration (IC50) as low as $24 \mathrm{nM}$, these sulfolipids effectively and selectively blocked the DNA polymerase activity of HIV-1 reverse transcriptase [108]. Ayehunie et al. demonstrated that an aqueous extract of Cyanobacterium (Arthrospira platensis) containing polysaccharides suppressed syncytium formation and HIV-1 replication in human PBMC, T-cell lines, and Langerhans cells at nontoxic concentrations [110]. Calcium spirulan, a sulfated polysaccharide, was isolated from the aqueous extract of Spirulina platensis marine blue-green alga. Further, the inhibitory effect of calcium spirulan on a viral replication of measles, HIV-1, herpes simplex virus-1 (HSV-1), mumps, polio, and influenza A was assessed through different cell lines. Calcium spirulan has been shown to impede the reproduction of several enveloped viruses, including HIV-1, HSV-1, influenza A, mumps, and measles. It clearly shows that the calcium spirulan limited the viral penetration into the host cells in a selective manner [111]. Boyd et al. have isolated virucidal protein (cyanovirin-N) from the aqueous cellular extract of Cyanobacterium (Nostoc ellipsosporum). The cyanovirin-N inhibited primate retrovirus multiplication (HIV-1 and HIV-2) in vitro at nanomolar concentrations. Cyanovirin-N exerts these antiviral effects through interactions with the viral envelope glycoprotein that seem to be preserved [112].

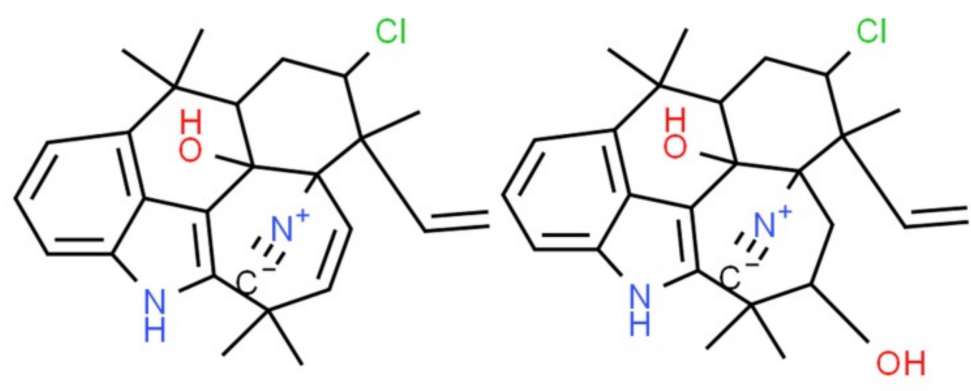

(5) Ambiguine-K isonitrile

(6) Ambiguine-M isonitrile

Figure 3. Structural representation of antimicrobial compounds 5 and $\mathbf{6}$ derived from marine Cyanobacteria.

\subsection{Antimicrobial Potential of Marine Firmicutes}

Firmicutes is a phylum of Gram-positive bacteria. Few have a permeable pseudo-outer membrane that leads them to stain Gram-negative. Due to their ecological variety and unique physiological and molecular features, these bacteria have received much attention in recent decades. They offer a lot of promise for biotechnological applications. Bacillus is one of the most important groups of Firmicutes. Bacillus sp. has a high-temperature tolerance and can grow quickly in liquid culture. Bacillus species are frequently isolated from marine sediment samples and other marine habitats $[113,114]$.

Recently, a novel oxatetracyclo ketone antimicrobial compound containing B. stercoris MBTDCMFRI Ba37 strain was isolated from estuarine habitats. The isolated compound inhibited the growth of aquatic bacterial pathogens belonging to the genera Aeromonas and Vibrio [115]. Further, a novel antagonistic secondary metabolite, bacilysin (Figure 4, Compound 7), was extracted from seaweed-associated B. amyloliquefaciens MTCC 10456. It showed selective antifungal activity against Malassezia globosa and M. furfur [116]. Wang et al. have reported the antibacterial activity of a new thiopeptide-class antibiotic, micrococcin (Figure 4, Compound 8), isolated from marine-derived B. stratosphericus. It showed potent antibacterial activity against Gram-positive bacterial pathogens without considerable cytotoxicity, up to a concentration of $10 \mu \mathrm{M}$ [117]. 


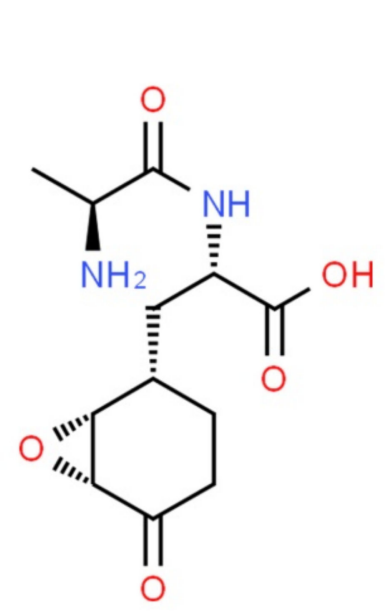

(7) Bacilysin

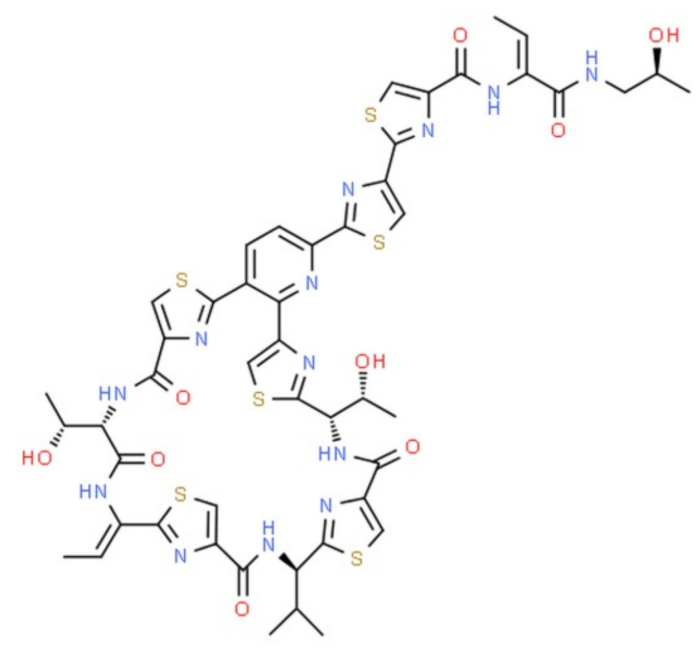

(8) Micrococcin

Figure 4. Structural representation of antimicrobial compounds $\mathbf{7}$ and $\mathbf{8}$ derived from marine Firmicutes.

\subsection{Antimicrobial Potential of Marine Planctomycetes}

Planctomycetes is a phylum of bacteria with a low frequency of occurrence. This bacterial group is often found in freshwater, soil, and marine environments. Planctomycetes may be free-living or adhere to biotic and abiotic surfaces [118]. Bacteria belonging to the phylum Planctomycetes are critical components of the marine nitrogen and carbon cycles, acting as scavengers after phototrophic blooms [119]. An exploration of Planctomycetes genome revealed the possibility of their producing antimicrobial polyketides, nonribosomal peptides, terpenoids, and bacteriocins. According to mass spectrometry studies, the unique bacteria of this group have also produced a new class of antimicrobial compounds [120,121].

In a recent study, stieleriacine, a novel class of $\mathrm{N}$-acylated tyrosines, was isolated from the marine Planctomycete strain Stieleria maiorica Mal15 ${ }^{\mathrm{T}}$. It reduced the growth and biofilm of the producing strain, S. maiorica Mal15 ${ }^{\mathrm{T}}$, and the co-occurring marine bacterial species, respectively [122]. Similarly, in another study, N-acylated dehydrotyrosine derivative compound, namely, stieleriacine $\mathrm{D}$, was isolated from marine Planctomycete strain S. neptunia sp. nov. It inhibited the growth of S. aureus and Micrococcus luteus at the concentrations of 16.7 and $66.7 \mu \mathrm{g} / \mathrm{mL}$, respectively [119].

\subsection{Antimicrobial Potential of Marine Proteobacteria}

Proteobacteria is the most diverse phylum of Gram-negative bacteria. The group is split into six classes, some identified by Greek letters spanning from Alpha to Epsilon, while others are known as Oligoflexia and Acidithiobacillia [70]. Previous research has shown that Proteobacteria may dominate microbial communities, even in deep-sea environments [123,124]. The marine bacterial phyla Proteobacteria are frequently reported as major bioactive chemical producers in marine macro-organisms. They can produce biologically active molecules with antibacterial, antiviral, antibiofilm, antifouling, and anticancer activities [125].

The Pseudoalteromonas species, associated with marine invertebrates and seaweed, have been identified as producers of the enormously potent antibiotic molecule, thiomarinol [126]. Recently, Dat et al. have examined the diversity and antimicrobial activity of cultivable bacteria in Vietnamese sponges. A total of 460 cultivable bacterial isolates were isolated from 18 marine sponges, in which nearly $58 \%$ of the bacteria belonged to the phylum Proteobacteria. Moreover, they have identified secondary metabolites, such as macrolactin A (Figure 5, Compound 9), and macrolactin H (Figure 5, Compound 10), as the major bioactive compounds. The isolated compounds exhibited strong antibacterial actions against a wide range of pathogenic organisms [127]. 


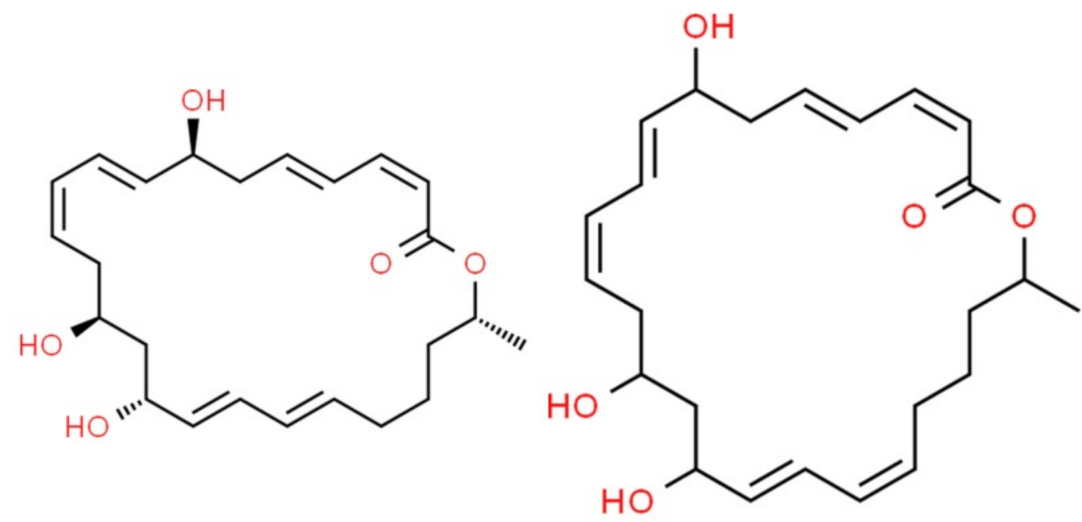

(9) Macrolactin A

(10) Macrolactin H

Figure 5. Structural representation of antimicrobial compounds $\mathbf{9}$ and $\mathbf{1 0}$ derived from marine Proteobacteria.

\section{Antimicrobial Potential of Marine Sediment-Derived Bacteria}

Since the 1940s, the soil has been viewed as the primary source for isolating antibiotic compounds. A shift from soil to other sources, such as marine sediment, has been seen in recent decades [128]. Sediment refers to any solid particle of inorganic or organic materials. Marine sediments include those found near the shore, such as rocks and cobbles, seashell fragments, and sand, and in the mud at the bottom of ocean waters. Furthermore, the continental and oceanic crust, volcanoes, chemical processes, outer space, microorganisms, and plants and animals, all influence the formation of marine sediments [129]. Marine sediments may be classified into two types based on their source area: near-shore sediments and deep-sea sediments. Numerous bacterial strains isolated from near-shore sediments are closely related to strains previously identified in soil [130]. This is because, unsurprisingly, many studies on the isolation of marine bacterial isolates from near-shore sediments have yielded the known secondary metabolites. As a result, access to marine deep-sea sediments has become a priority, increasing the probability of discovering novel marine bacterial isolates $[70,128]$.

Macrolactins are 24-membered lactone natural products with several pharmacological activities, making them attractive therapeutic candidates. They are mainly generated by marine-derived microorganisms [128]. A Macrolactin class of antibacterial and antiviral drugs were isolated from unclassified deep-sea sediment marine bacteria. Among the different macrolactins isolated, macrolactin A showed potent antibacterial activity against S. aureus and B. subtilis. Additionally, macrolactin A was an effective inhibitor of the HSV type-1 (strain LL) and type-2 viruses (strain G), with IC50 values of 5.0 and $8.3 \mu \mathrm{g} / \mathrm{mL}$, respectively [129]. Marine Streptomyces sp. B7064 was isolated in mangrove sediment in Pohoiki, Hawaii, and was found to produce chalcomycin (Figure 6, Compound 11), a novel macrolide antibiotic. The compound exhibited potent antibacterial activity against S. aureus, E coli, and B. subtilis, with minimum inhibitory concentration (MIC) values of 0.39, 750, and $6.25 \mu \mathrm{g} / \mathrm{mL}$, respectively [131]. Aborycin (Figure 6, Compound 12) was extracted and identified from the Streptomyces sp., which was isolated from the deep-sea sediments of the South China Sea [132]. With MIC values ranging from 8.0-128 $\mu \mathrm{g} / \mathrm{mL}$, the compound showed moderate bacteriostatic activity against different strains of $S$. aureus. Further, this secondary metabolite inhibited E. faecalis and B. thuringiensis at the MIC values of 8.0 and $2.0 \mu \mathrm{g} / \mathrm{mL}$, respectively. A novel polyketide compound abyssomicin $Y$ (Figure 6, Compound 13) was isolated from the marine-sediment-derived Verrucosispora strain MS100137, which exhibited potent antiviral activity against the influenza A virus at a concentration of $10 \mu \mathrm{M}$ [133]. 


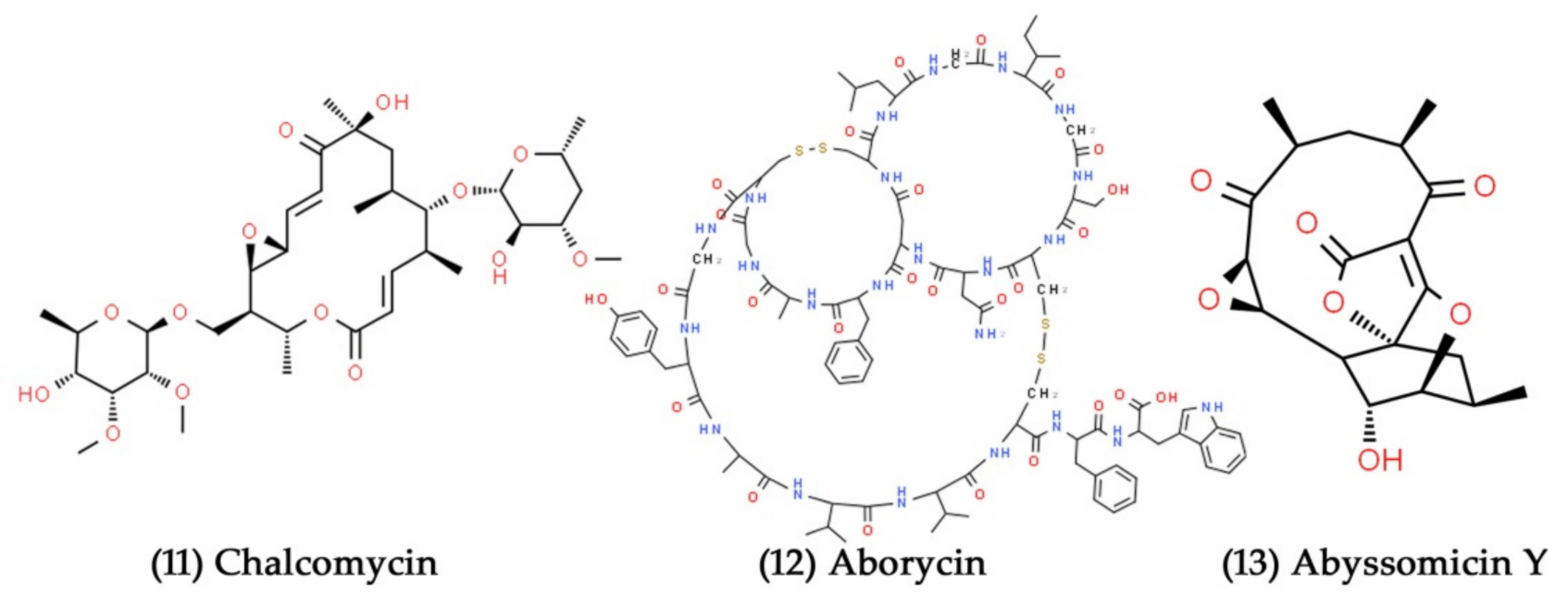

Figure 6. Structural representation of antimicrobial compounds 11-13 from sediment-derived marine bacteria.

Certain marine bacteria have great potential for producing varied and remarkable characteristics, such as pigment production [134]. These marine-pigmented bacteria have been shown to possess various biological functions, including antibacterial, anticancer, antifungal, and immunosuppressive functions [135]. The red-pigmented prodigiosin compound was first isolated and identified as a secondary metabolite from the ubiquitous bacteria Serratia marcescens [136]. Apart from S. marcescens, many marine bacteria belonging to the genera Actinomadura, Pseudoalteromonas, Pseudomonas, and Streptomyces have been reported to produce red-pigmented prodigiosin and related compounds [137-139]. The Hahella sp. isolated from the sediment sample from Nagasaki Prefecture, Japan, secreted enormous amounts of redpigmented prodigiosin (Figure 7, Compound 14), which showed excellent antibacterial activity against different strains of $S$. aureus [140]. The polyketide ansalactams A-D are radically modified ansamycins that were obtained from the marine sediment culture of Streptomyces sp. CNH189. The antibacterial activity of ansalactams B, C, and D (Figure 7, Compounds 15-17) against $S$. aureus was moderate, with MICs of 31.2, 31.2, and $62.5 \mu \mathrm{g} / \mathrm{mL}$, respectively. In contrast, ansalactam A was inactive up to $100 \mu \mathrm{g} / \mathrm{mL}$ [141].

Marine bacteria are the major source of structurally distinct and biologically significant nonribosomal peptides, particularly cyclopeptide derivatives. Yang et al. isolated three cyclopeptides derivatives, the halolitoralins A, B, and C, from the marine-sedimentderived Halobacillus litoralis YS3106 strain. In comparison to the other two cyclopeptides, halolitoralin A (Figure 8, Compound 18) has efficient antifungal activity against Tricophyton rubrum and C. albicans at the concentrations of 25 and $20 \mu \mathrm{g} / \mathrm{mL}$, respectively [142]. Atratumycin (Figure 8, Compound 19) is a cyclic dipeptide that exhibits antibacterial action against $M$. tuberculosis, with MIC values of 14.6 and $3.8 \mu \mathrm{M}$ against the M. tuberculosis $\mathrm{H} 37 \mathrm{Rv}$ and H37Ra strains, respectively. It was isolated from an extract of S. atratus from the deep-sea sediments of the South China Sea [132]. Streptomyces sp. SMS636 extract yielded albonoursin (Figure 8, Compound 20), and streptonigrin (Figure 8, Compound 21), recovered from deep-sea sediments in the South China Sea. With MIC values of 12.5 and $0.78 \mu \mathrm{g} / \mathrm{mL}$, respectively, albonoursin and streptonigrin exhibited substantial antibacterial activity against $S$. aureus [143]. Engelhardt et al. isolated eighteen actinomycete strains from the marine sediment sample collected in the Trondheim Fjord, Norway. Among the eighteen actinomycete extracts, a total of 4 and 10 actinomycete fermentation extracts substantially inhibited the growth of C. albicans ATCC 10231 and M. luteus ATCC 9341, respectively. They then purified and identified novel thiopeptide antibiotic TP-1161 (Figure 8, Compound 22) from the active extracts [144]. In another study, the novel depsipeptide antibacterial compound, fijimycin A (Figure 8, Compound 23), was isolated from marine sediment-derived Streptomyces sp. and showed profound antibacterial activity against different strains of $S$. aureus with MIC values between 4 and $16 \mu \mathrm{g} / \mathrm{mL}$ [145]. 


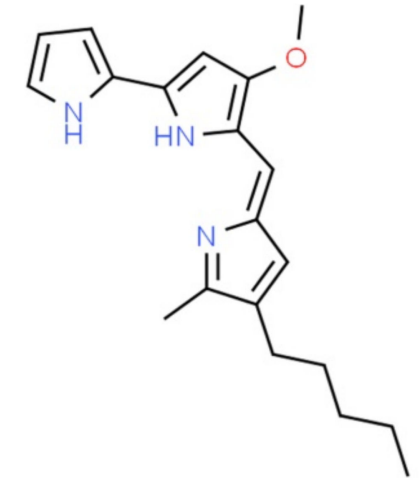

(14) Prodigiosin<smiles>CC(=C/C(C)=C\[C@H](C)/C=C(\C)C(=O)O)C(=O)C12C[C@]3(NC(=O)[C@H](CC(C)C)[C@@H]13)c1cc(O)c(C)cc1C2=O</smiles>

(16) Ansalactam C

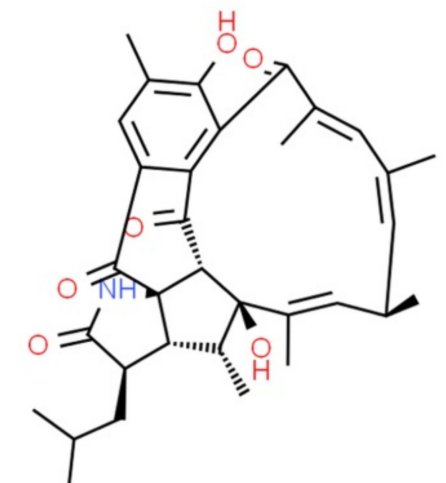

(15) Ansalactam B

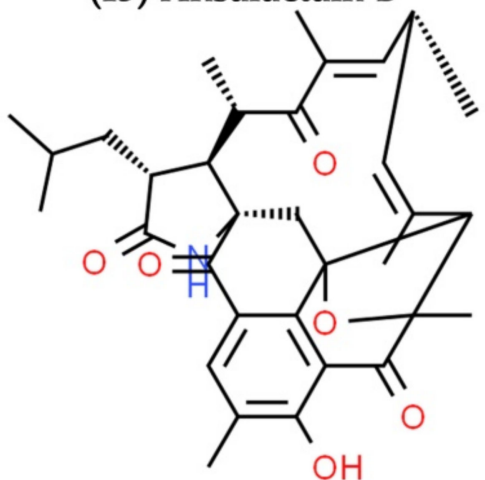

(17) Ansalactam D

Figure 7. Structural representation of antimicrobial compounds 14-17 from sediment-derived marine bacteria.<smiles>CCC(C)[C@@H]1NC(=O)[C@@H](C(C)CC)NC(=O)[C@H](C)NC(=O)[C@H](CC(C)C)NC(=O)[C@H](C)NC1=O</smiles>

(18) Halolitoralin A<smiles></smiles>

(21) Streptonigrin

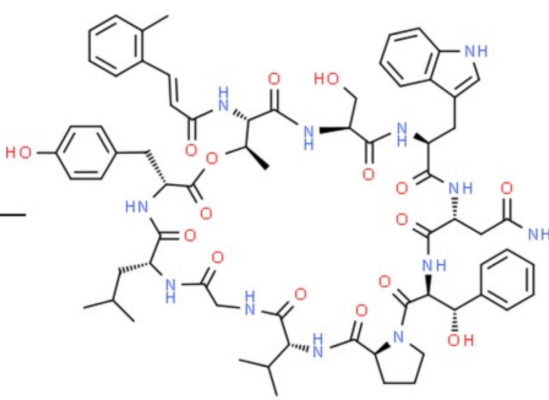

(19) Atratumycin<smiles>CC(C)/C=c1\[nH]c(=O)/c(=C/c2ccccc2)[nH]c1=O</smiles>

(20) Albonoursin

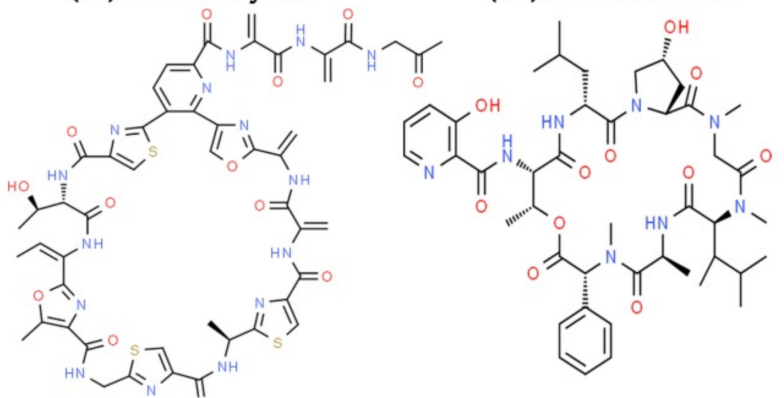

(22) Thiopeptide TP-1161

(23) Fijimycin A

Figure 8. Structural representation of antimicrobial compounds 18-23 from sediment-derived marine bacteria.

The cocultivation of two or more microorganisms has gained increased attention due to the possibility of finding novel bioactive natural compounds [146]. The cocultivation of marine sediment-derived bacterial strains, such as Janthinobacterium sp. ZZ145 and ZZ148, induced the production of two novel polyketides, including janthinopolyenemycins 
A and B (Figure 9, Compounds 24 and 25). Furthermore, both janthinopolyenemycins $A$ and B exhibited excellent antifungal activity against $C$. albicans with a MIC value of $15.6 \mu \mathrm{g} / \mathrm{mL}$ [147]. In another study, Cho et al. isolated the actinomycete strain (S. cinnabarinus PK209) from marine sediment collected from the coast of Korea. They cocultivated the S. cinnabarinus PK209 with Alteromonas sp. to induce the production of the diterpene compound lobocompactol (Figure 9, Compound 26). Then, the overproduced lobocompactol was tested for their growth inhibitory potential. The obtained data revealed that lobocompactol acted as an antifouling agent on macroalga Ulva pertusa by preventing the attachment and growth of different fouling bacteria [148].<smiles>C/C=C(\C)C1C(C)=C[C@@H]2[C@H](CC[C@H](C)[C@H]2O)[C@]1(C)/C=C/C=C/C=C/C=C/C(=O)O</smiles>

(24) Janthinopolyenemycin A

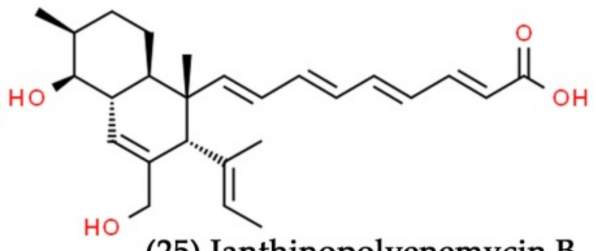

(25) Janthinopolyenemycin B

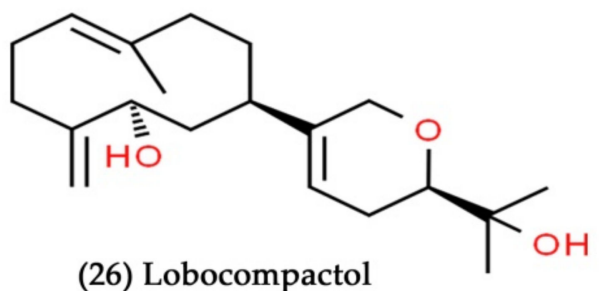

Figure 9. Structural representation of antimicrobial compounds 24-26 from sediment-derived marine bacteria.

\section{Antimicrobial Potential of Marine Water-Derived Bacteria}

Microbial life in marine water is diverse, with bacteria, viruses, fungi, and spores being the most prevalent [40]. Novel antibacterial dipeptide compounds, such as unnarmicins A and C, were extracted from marine bacterium Photobacterium sp. MBIC06485. This marine bacterial strain was isolated from the coastal seawater collected from Onna Beach, Okinawa, Japan. The isolated dipeptide compounds selectively inhibited the two marine environmental pathogenic strains, Alphaproteobacteria and Pseudovibrio [149]. A bioassay-guided fractionation of a fermentation broth of Pseudonocardia carboxydivorans M-227, isolated from deep-seawater in the Avilés submarine canyon, disclosed the presence of two antibiotic molecules, branimycins B and C (Figure 10, Compounds 27 and 28). These two antibiotic molecules exhibited moderate to substantial antibacterial activities against different Grampositive and Gram-negative bacterial pathogens [150]. The marine bacteria Pseudomonas UJ-6, isolated from the seawater sample, has been shown to possess the secondary metabolite 1-acetyl-beta-corboline (Figure 10, Compound 29). Further, the bioactive compound extracted from Pseudomonas UJ-6 had antibacterial action against $S$. aureus with the MIC range of 32-128 $\mu \mathrm{g} / \mathrm{mL}$ [151]. Arisostatin B (Figure 10, Compound 30), a novel tetroarcin antibiotic, was extracted from the cultivated broth of the Micromonospora sp. obtained from sea water in Toyama Bay, Japan. At concentrations of 3.1,25, and $50 \mu \mathrm{g} / \mathrm{mL}$, respectively, arisostatin B inhibited the growth of M. luteus, B. subtilis, and S. aureus [152]. Arena et al. extracted the exopolysaccharide (EPS) from B. licheniformis, isolated from shallow marine water from the hot spring on Vulcano Island, Italy. The extracted EPS potentially enhanced the innate immunity of human peripheral blood mononuclear cells (PBMC) against the herpesvirus [HSV-1] infection by promoting Th1-type cytokine polarization [153]. Furthermore, the same research group extracted EPS from the marine Geobacillus thermodenitrificans, isolated from the deep-sea vent of Vulcano Island, Italy. They found that the EPS treatment inhibited HSV-1 multiplication in PBMC by elevating the amounts of IL-12, IL-18, TNF-, and IFN- [154]. 


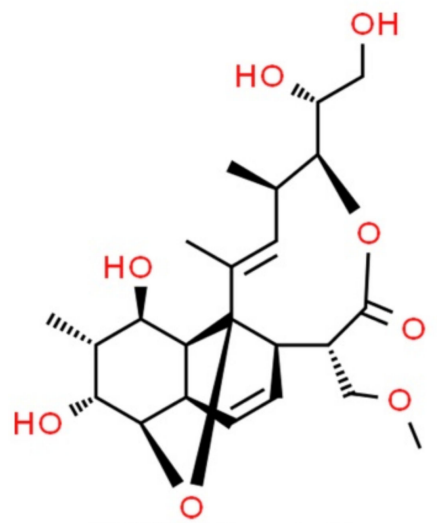

(27) Branimycin B

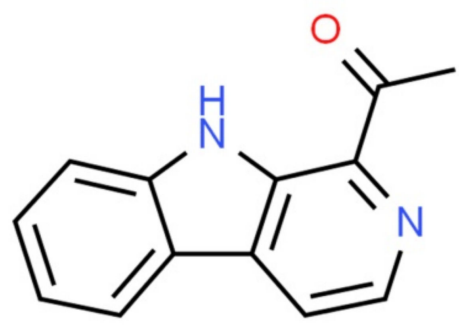

(29) 1-acetyl-beta-corboline

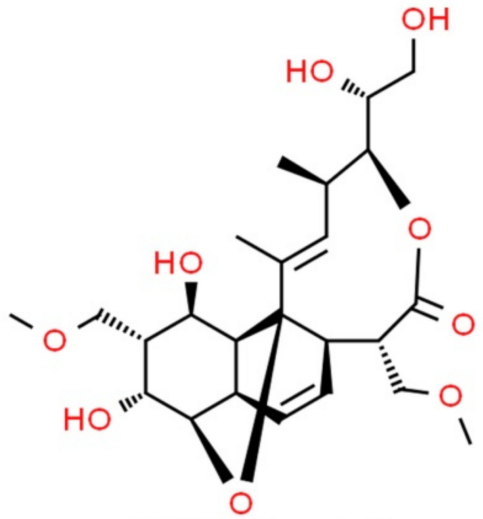

(28) Branimycin C

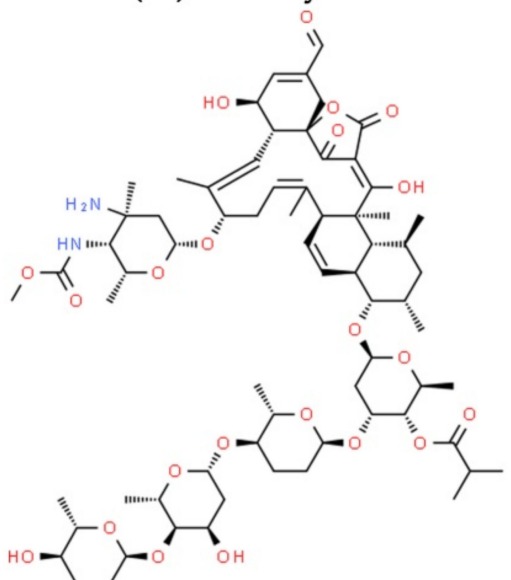

(30) Arisostatin B

Figure 10. Structural representation of antimicrobial compounds 27-30 from water-derived marine bacteria.

In addition to these, several marine bacterial isolates derived from marine sediments and water have been well-reported for their antimicrobial activities, which are tabulated in Table 1.

Table 1. Antimicrobial potential of marine bacteria derived from marine sediments/water.

\begin{tabular}{cclll}
\hline $\begin{array}{c}\text { S. } \\
\text { No }\end{array}$ & Marine Source & Marine Bacteria & Secondary Metabolite(s) & \multicolumn{1}{c}{ Antimicrobial Activity } \\
\hline 1 & Sediment sample & $\begin{array}{l}\text { Nonomuraea sp. } \\
\text { MM565M-173N2 }\end{array}$ & Sealutomicin A & $\begin{array}{l}\text { Inhibited the growth of } \\
\text { carbapenem-resistant Enterobacteriaceae }\end{array}$ \\
\hline 2 & Sediment sample & Streptomyces sp. & - & $\begin{array}{l}\text { Exhibited antifungal activity } \\
\text { against } \text { C. albicans }\end{array}$ \\
\hline 3 & Sediment sample & Actinomycete AMA50 & $\begin{array}{l}\text { Tetradecanoic acid, } \\
\text { pentadecanoic acid, and } \\
\text { n-hexadecanoic acid }\end{array}$ & $\begin{array}{l}\text { Exhibited antifungal activity against } \\
\text { Talaromyces marneffei }\end{array}$ \\
\hline 4 & Sediment sample & $\begin{array}{l}\text { Streptomyces sp. } \\
\text { SY1965 }\end{array}$ & Streptothiazolidine A & $\begin{array}{l}\text { Exhibited antifungal activity } \\
\text { against C. albicans }\end{array}$ \\
\hline 5 & Sediment sample & B. velezensis SH-B74 & Anteiso-C15 Ile2,7 surfactin, 1 1 & $\begin{array}{l}\text { Inhibited the appressoria formation of rice } \\
\text { blast fungal pathogen Magnaporthe oryzae }\end{array}$ \\
\hline 6 & Sediment sample & [159] & $\begin{array}{l}\text { Showed antifungal activity against } \\
\text { Verticillium dahlia CICC 2534 and Fusarium } \\
\text { oxysporumf. sp. cucumerinum CICC 2532 }\end{array}$ \\
\hline [160]
\end{tabular}


Table 1. Cont.

\begin{tabular}{|c|c|c|c|c|c|}
\hline $\begin{array}{l}\text { S. } \\
\text { No }\end{array}$ & Marine Source & Marine Bacteria & Secondary Metabolite(s) & Antimicrobial Activity & Ref \\
\hline 9 & Sediment sample & Salinispora arenicola & $\begin{array}{l}\text { 3-hydroxy- } N \text {-methyl-2- } \\
\text { oxindole derivatives }\end{array}$ & Inhibited the growth of E. faecalis & [163] \\
\hline 10 & Estuary soil sample & S. felleus & Polyketide compounds & $\begin{array}{l}\text { Exhibited antibacterial activity against } \\
\text { Enterococcus sp. }\end{array}$ & [164] \\
\hline 11 & Sediment sample & S. arenicola & Salinaphthoquinones & $\begin{array}{l}\text { Exhibited moderate antibacterial activity } \\
\text { against } E \text {. faecalis and S. aureus }\end{array}$ & [165] \\
\hline 12 & Sediment sample & Streptomyces sp. & Meroterpenoids & $\begin{array}{l}\text { Showed intense antibacterial activity against } \\
\text { B. subtilis and S. aureus }\end{array}$ & [166] \\
\hline 13 & Sediment sample & $\begin{array}{l}\text { Streptomyces sp. } \\
\text { RKND004 }\end{array}$ & Terrosamycins A and B & $\begin{array}{l}\text { Exhibited strong antibacterial activity } \\
\text { against Gram-positive bacteria }\end{array}$ & [167] \\
\hline 14 & Sediment sample & Streptomyces strains & - & $\begin{array}{l}\text { Exhibited antifungal activity against } \\
\text { C. albicans and } A \text {. niger }\end{array}$ & [168] \\
\hline 15 & Sediment sample & Streptomyces sp. 4054 & Mycenolide A & Inhibited the growth of $B$. subtilis & [169] \\
\hline 16 & Sediment sample & $\begin{array}{l}\text { S. xinghaiensis } \\
\text { SCSIO S15077 }\end{array}$ & Tunicamycin derivatives & $\begin{array}{l}\text { Showed both antibacterial and } \\
\text { antifungal activities }\end{array}$ & [170] \\
\hline 17 & Sediment sample & $\begin{array}{l}\text { Bacillus and } \\
\text { Virgibacillus strains }\end{array}$ & - & $\begin{array}{l}\text { Exhibited antibacterial activity against } \\
\text { S. aureus and V. parahaemolyticus }\end{array}$ & {$[171]$} \\
\hline 18 & Sediment sample & Actinobacteria SJP4 & {$[1,2,4]$ triazol-1-ylethanone } & $\begin{array}{l}\text { Exhibited antibacterial activity against both } \\
\text { Gram-positive and Gram-negative bacteria }\end{array}$ & [172] \\
\hline 19 & Sediment sample & $\begin{array}{l}\text { Streptomyces sp. } \\
\text { Bacillus sp. and } \\
\text { Micrococcus sp. }\end{array}$ & - & $\begin{array}{l}\text { Showed both antibacterial and } \\
\text { antifungal activities }\end{array}$ & [173] \\
\hline 20 & Sediment sample & S. mutabilis sp. MII & $\mathrm{N}$-acetylborrelidin B & $\begin{array}{l}\text { Exhibited both antibacterial and antifungal } \\
\text { activities }\end{array}$ & [174] \\
\hline 21 & $\begin{array}{l}\text { Mangrove sediment } \\
\text { sample }\end{array}$ & Streptomyces & - & $\begin{array}{l}\text { Exhibited antibacterial activity against both } \\
\text { Gram-positive and Gram-negative bacteria }\end{array}$ & [175] \\
\hline 22 & $\begin{array}{l}\text { Mangrove sediment } \\
\text { sample }\end{array}$ & Actinobacteria & Extracellular enzymes & $\begin{array}{l}\text { Exhibited both antibacterial and } \\
\text { antifungal activities }\end{array}$ & [176] \\
\hline 23 & Sediment sample & $\begin{array}{l}\text { Aneurinibacillus sp. } \\
\text { YR247 }\end{array}$ & Peptidic compounds & $\begin{array}{l}\text { Showed antifungal activity against } \\
\text { A. brasiliensis NBRC } 945\end{array}$ & [177] \\
\hline 24 & Sediment sample & $\begin{array}{l}\text { Rheinheimera japonica } \\
\text { KMM } 9513 \mathrm{~T}\end{array}$ & Diketopiperazines & $\begin{array}{l}\text { Inhibited the growth of B. subtilis, S. aureus } \\
\text { and E. faecium }\end{array}$ & [178] \\
\hline 25 & Sediment sample & T. flavus SP5 & $\begin{array}{l}\text { Different bioactive } \\
\text { compounds }\end{array}$ & $\begin{array}{l}\text { Inhibited growth of both bacterial and } \\
\text { fungal pathogens }\end{array}$ & [179] \\
\hline 26 & $\begin{array}{l}\text { Mangrove sediment } \\
\text { sample }\end{array}$ & $\begin{array}{l}\text { S. parvulus } \\
\text { DOSMB-D105 }\end{array}$ & $\begin{array}{l}\text { Different bioactive } \\
\text { compounds }\end{array}$ & $\begin{array}{l}\text { Exhibited both antibacterial and } \\
\text { antifungal activities }\end{array}$ & [180] \\
\hline 27 & Sediment sample & R. japonica sp. & Isoprenoid quinones & $\begin{array}{l}\text { Exhibited strong antagonistic activity } \\
\text { against both Gram-positive and } \\
\text { Gram-negative bacteria }\end{array}$ & [181] \\
\hline 28 & Sediment sample & $\begin{array}{l}\text { Streptomyces sp. } \\
\text { CMB-M0244 }\end{array}$ & Mollemycin A & $\begin{array}{l}\text { Exhibited antibacterial activity against both } \\
\text { Gram-positive and Gram-negative bacteria }\end{array}$ & [182] \\
\hline 29 & Sediment sample & B. sonorensis MT93 & Sonorensin & $\begin{array}{l}\text { Exhibited broad spectrum of antibacterial } \\
\text { activity against different bacterial pathogens }\end{array}$ & [183] \\
\hline 30 & Sediment sample & $\begin{array}{l}\text { Streptosporangium sp. } \\
\text { DSM } 45942\end{array}$ & Iodinin & $\begin{array}{l}\text { Exhibited both antibacterial and } \\
\text { antifungal activities }\end{array}$ & [184] \\
\hline 31 & Sediment sample & $\begin{array}{l}\text { Streptomyces sp. } \\
\text { 12A35 }\end{array}$ & Lobophorin I & $\begin{array}{l}\text { Exhibited antibacterial activity against } \\
\text { S. aureus and B. subtilis }\end{array}$ & [185] \\
\hline 32 & Sediment sample & $\begin{array}{l}\text { Actinoalloteichus sp. } \\
\text { NPS702 }\end{array}$ & Neomaclafungins & $\begin{array}{l}\text { Showed strong antifungal activity against } \\
\text { Trichophyton mentagrophytes }\end{array}$ & [186] \\
\hline 33 & Sediment sample & $\begin{array}{l}\text { Pseudonocardia sp. } \\
\text { SCSIO } 01299\end{array}$ & Pseudonocardians A-C & $\begin{array}{l}\text { Exhibited antibacterial activity against both } \\
\text { Gram-positive and Gram-negative bacteria }\end{array}$ & [187] \\
\hline
\end{tabular}


Table 1. Cont.

\begin{tabular}{|c|c|c|c|c|c|}
\hline $\begin{array}{l}\text { S. } \\
\text { No }\end{array}$ & Marine Source & Marine Bacteria & Secondary Metabolite(s) & Antimicrobial Activity & Ref \\
\hline 34 & Sediment sample & $\begin{array}{l}\text { Streptomyces sp. } \\
\text { NTK } 937\end{array}$ & Caboxamycin & $\begin{array}{l}\text { Exhibited antibacterial activity against } \\
\text { Gram-positive bacterial pathogens }\end{array}$ & [188] \\
\hline 35 & Sediment sample & B. laterosporus Lh-1 & - & $\begin{array}{l}\text { Exhibited antibacterial activity against both } \\
\text { Gram-positive and Gram-negative bacteria }\end{array}$ & [189] \\
\hline 36 & Sediment sample & $\begin{array}{l}\text { Streptomyces sp. } \\
\text { BD21-2 }\end{array}$ & Bonactin & $\begin{array}{l}\text { Exhibited antibacterial activity against both } \\
\text { Gram-positive and Gram-negative bacteria }\end{array}$ & [190] \\
\hline 37 & Sediment sample & $\begin{array}{l}\text { S. koyangensis } \\
\text { SCSIO } 5802\end{array}$ & Neoabyssomicins & $\begin{array}{l}\text { Exhibited antiviral activity against HSV and } \\
\text { vesicular stomatitis virus }\end{array}$ & [191] \\
\hline 38 & Sediment sample & $\begin{array}{l}\text { Streptomyces. sp. } \\
\text { \#HK18 }\end{array}$ & Xiamycin C & $\begin{array}{l}\text { Exhibited strong antiviral activity against } \\
\text { porcine epidemic diarrhea virus }\end{array}$ & [192] \\
\hline 39 & Water sample & P. putida & $\begin{array}{l}\text { 9, 10-dihydrophenanthrene-2- } \\
\text { carboxylic acid }\end{array}$ & $\begin{array}{l}\text { Revealed strong antifungal activity against } \\
\text { C. albicans }\end{array}$ & [193] \\
\hline 40 & Water sample & $\begin{array}{l}\text { Bacillus, Arthrobacter, } \\
\text { and Brevundimonas }\end{array}$ & - & $\begin{array}{l}\text { Exhibited antibacterial activity against both } \\
\text { Gram-positive and Gram-negative bacteria }\end{array}$ & [194] \\
\hline 41 & Water sample & $\begin{array}{l}\text { Pseudoalteromonas } \\
\text { haloplanktis TAC125 }\end{array}$ & Methylamine & $\begin{array}{l}\text { Inhibited the growth of } \\
\text { Burkholderia cepacia complex }\end{array}$ & [195] \\
\hline 42 & $\begin{array}{l}\text { Estuarine water } \\
\text { sample }\end{array}$ & $\begin{array}{l}\text { Different strains of } \\
\text { heterotrophic } \\
\text { bacteria }\end{array}$ & - & Inhibited the growth of S. aureus and E. coli & [196] \\
\hline
\end{tabular}

\section{Marine Fauna}

Marine fauna is extremely diverse and encompasses living organisms from microscopic zooplankton to blue whales. The marine fauna classification includes all animals and living organisms present in the ocean, regardless of their size. They play critical roles in maintaining key ecological processes and functions within the marine ecosystem. Apart from these, certain marine fauna act as a treasure house for synthesizing several novel bioactive compounds. The following sections intensely discuss the antimicrobial potentials of marine bacteria associated with certain important marine fauna, such as sponges, corals, and mollusks.

\subsection{Antimicrobial Potential of Bacteria Associated with Marine Sponges}

Marine sponges contribute significantly to benthic communities worldwide, both in biomass and their ability to affect benthic or pelagic processes [197]. Sponges are abundant in tropical reefs, but they also inhabit polar regions, the deep sea, and freshwater lakes and rivers. They are one of the oldest multicellular invertebrates and exist in a broad range of colors and textures. To date, over 8000 sponge species have been identified in various marine and freshwater environments [198]. Marine sponges are habitat to a diverse array of microbial communities, including bacteria, fungi, archaea, and viruses, which provide an essential source of natural products. Microbial biomass may take up to $35 \%$ of the sponge's volume. These sponges are classified as "high-microbial abundance". The true origin of several sponge-derived secondary metabolites remains unclear to date. Secondary metabolites may be generated by sponges, their microbial symbionts, or the interactions between sponges and symbionts [199]. Interestingly, many studies have shown that several bioactive compounds discovered in sponges may be of bacterial origin, according to the chemical structural resemblance to those found in terrestrial and marine microorganisms $[197,200]$. It suggests that sponge-associated bacteria, rather than the host, are the real producers. Furthermore, these symbiotic bacteria also play a significant role in the health and survival of marine sponges [201]. As a result, many researchers concentrate their efforts on sponge-associated bacteria, which may be used to screen and isolate bioactive compounds.

Recently, Altuğ et al. isolated the sponge-associated bacteria collected from the Sea of Marmara, Turkey. They then assessed the antibacterial potential of the methanolic 
extract of marine sponge-associated bacteria against different bacterial pathogens, such as S. aureus, Vibrio vulnificus, and E. coli. At the tested concentrations ( 7.8 to $1000 \mu \mathrm{g} / \mathrm{mL})$, the extracts significantly inhibited the growth of all the tested bacterial pathogens. Finally, they identified this efficient sponge-associated bacterium related to $B$. cereus through molecular identification [202]. The majority of actinomycetes obtained from marine sources are believed to have originated from marine sponges, with Streptomyces being the most common species [203]. Numerous studies have shown that the isolation of several novel bioactive compounds from Streptomyces is associated with marine sponges [204-206]. Around 22\% of the bioactive compounds are isolated from marine sponges associated with actinomycetes. In a recent study, Fahmy et al. have isolated the antimicrobial compounds from Streptomyces sp. associated with the marine sponge collected from the Egyptian Red Sea coast [62]. In another recent work, a novel antiviral compound, namely homoseongomycin, was isolated from marine sponge-associated actinomycete bacteria K3-1. It showed potent antiviral activity against alphaviruses, such as the eastern and Venezuelan equine encephalitis viruses, with 50\% effective concentrations of 1.2 and $8.6 \mu \mathrm{M}$, respectively [207]. Mitova et al. isolated a novel cyclopeptide compound, namely, cyclo-(glycyl-L-seryl-Lprolyl-L-glutamyl) (Figure 11, Compound 31) from the extract of marine Agrobacterium (Ruegeria strain) associated with the sponge Suberites domuncula. The isolated cyclopeptide has exhibited potent antibacterial activity against $B$. subtilis at the concentration of $25 \mu \mathrm{g} / \mathrm{mL}$ [208]. In another study, novel thiopeptide antibiotic substances, namely, YM266183 and YM-266184 (Figure 11, Compounds 32 and 33), were isolated from marine bacteria B. cereus QN03323 associated with the sponge Halichondria japonica. Further, both of these thiopeptide antibiotic substances have shown excellent growth inhibitory potential against Gram-positive bacterial pathogens [209]. A thiazolyl peptide derivative compound, kocurin (Figure 11, Compound 34), was extracted from the culture broth of Kocuria palustris. This bacterial strain was isolated from a marine sponge sample collected in the Florida Keys, United States of America (USA), and the compound kocurin showed excellent antibacterial and antifungal activities against certain bacterial and fungal pathogens [210].

The cocultivation of bacterial isolates obtained from marine sponges, such as Rhodococcus sp. and Micromonospora sp., stimulated the synthesis of a novel antibiotic molecule, keyicin (Figure 12, Compound 35). Further, the extracted bioactive compound keyicin selectively inhibited the growth of Gram-positive bacterial pathogens, especially Mycobacterium sp. and Rhodococcus sp. [211]. Similarly, the coculture of actinomycete (S. rochei MB037) derived from a marine sponge (Dysidea arenaria) with fungus (Rhinocladiella similis 35) stimulated the production of borrelidin J (Figure 12, Compound 36). The extracted fatty acid compound borrelidin J exhibited profound antibacterial action against $S$. aureus with a MIC value of $0.195 \mu \mathrm{g} / \mathrm{mL}$ [212]. In another study, the cocultivation of two marine sponge-derived actinomycetes, Nocardiopsis sp. RV163 and Actinokineospora sp. EG49, induced the production of ten different secondary metabolites related to $\beta$-carboline, diketopiperazine, and angucycline derivatives. Among them, the prenylated derivative compound 1,6-dihydroxyphenazine (Figure 12, Compound 37) only showed antibacterial activity against Bacillus sp. P25 [213].

\subsection{Antimicrobial Potential of Bacteria Associated with Marine Corals}

Corals, among marine organisms, are potential producers of marine bioactive compounds and have received a lot of attention. Deep-sea corals produce a variety of bioactive natural products with structurally diverse properties [214]. Microorganisms, primarily bacteria, have been shown to colonize different sections of coral tissues (gastrovascular cavity, mucus layer, and skeleton) and to have a role in coral development, health, and stress tolerance [215]. Further, earlier studies show that the coral microbiome protects coral hosts by producing antimicrobial agents, suppressing pathogenic metabolic enzymes, interrupting cell-to-cell communication systems, and competitively eliminating pathogens from the host cell surfaces [216-219]. Many structurally distinct bioactive compounds with 
a wide variety of pharmacological activities, including antimicrobial compounds, may be produced by coral-associated bacteria against a wide range of pathogenic organisms [218].

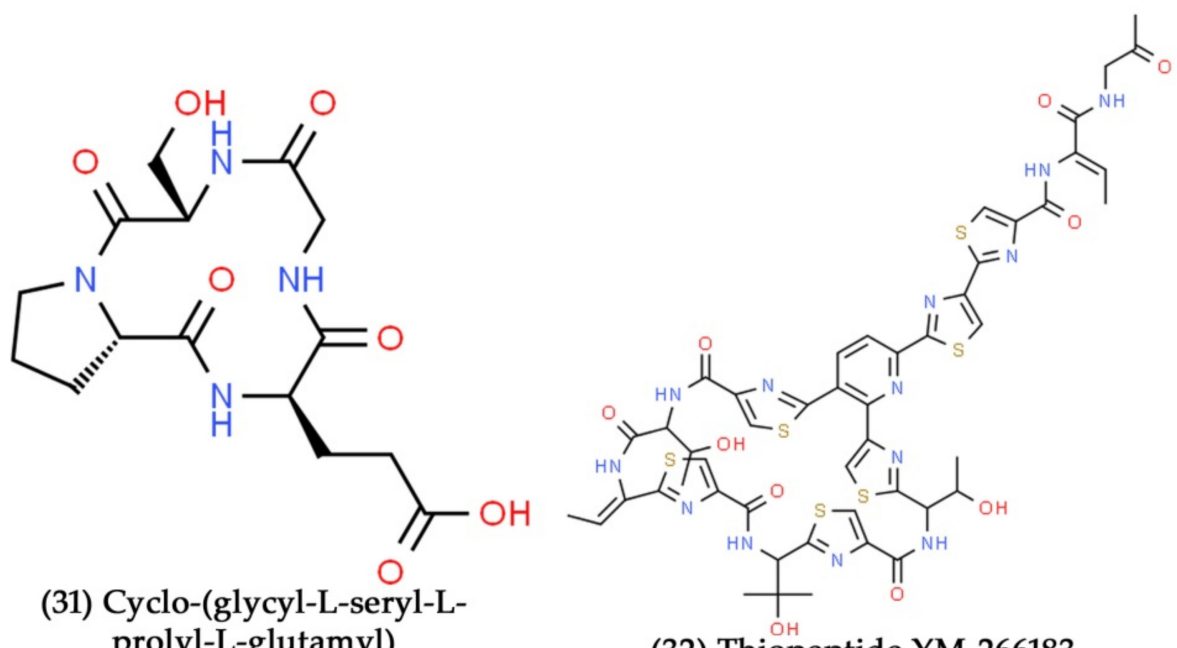

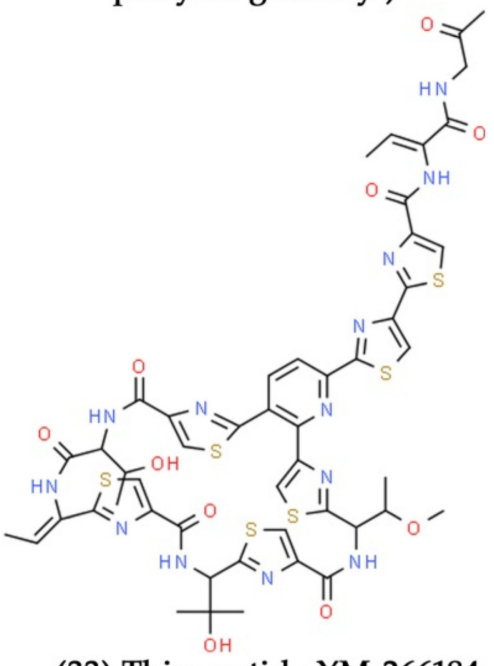

(33) Thiopeptide YM-266184
(32) Thiopeptide YM-266183

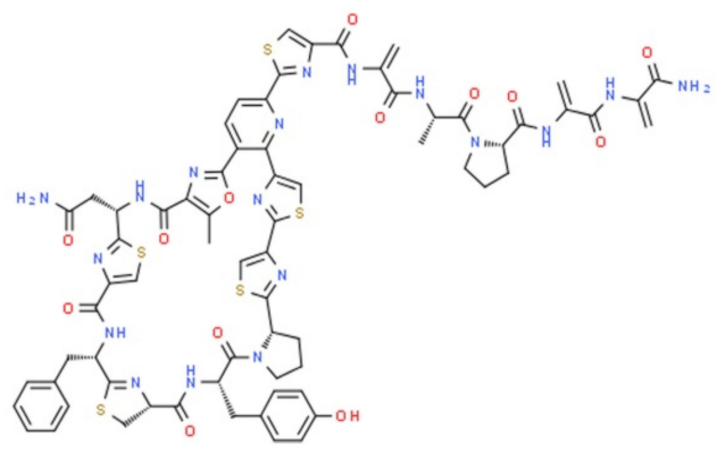

(34) Kocurin

Figure 11. Structural representation of antimicrobial compounds 31-34 derived from bacteria associated with marine sponges.

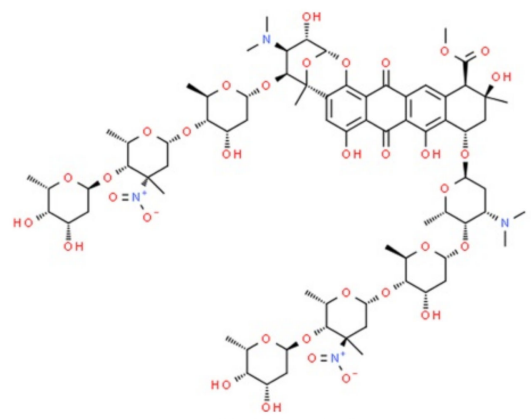

(35) Keyicin<smiles>C[C@@H](C[C@@H](C)C[C@@H](C)O)C[C@@H](C)[C@@H](O)/C(C#N)=C\C=C\C[C@@H](O)[C@@H]1CCC[C@H]1C(=O)O</smiles>

(36) Borrelidin J<smiles>Oc1cccc2nc3c(O)cccc3nc12</smiles>

(37) 1,6-dihydroxyphenazine

Figure 12. Structural representation of antimicrobial compounds 35-37 derived from bacteria associated with marine sponges.

Rodríguez et al. have isolated the strain S. cyaneofuscatus M-169 from a gorgonian coral obtained in the deep-sea water of Avilés Canyon, Cantabrian Sea. They then extracted the polyketide compound, anthracimycin (Figure 13, Compound 38), from the acidified ethyl 
acetate extract of $S$. cyaneofuscatus. It showed potent antibacterial activity against Grampositive bacterial pathogens, such as $S$. aureus, E. faecalis, and E. faecium, at the concentration of $0.03 \mu \mathrm{g} / \mathrm{mL}$ [220]. Watasemycin-A, aerugine, and pulicatin-G are three thiazole derivatives extracted from Streptomyces sp. OUCMDZ-1703, a coral-associated actinomycetes strain. Watasemycin-A (Figure 13, Compound 39) and aerugine (Figure 13, Compound 40) were the first compounds that exhibited strong antibacterial action against different clinical strains of S. aureus with the MIC value of $7.81 \mu \mathrm{g} / \mathrm{mL}$ [221]. Sarmiento-Vizcaíno et al. collected 87 deep-sea coral reef samples from the submarine Avilés Canyon, Spain. They then isolated 18 different cultivable Actinobacteria from the coral samples and tested their antimicrobial potential. The obtained results revealed that the isolated deep-sea Actinobacteria exhibited both antibacterial and antifungal activities [222]. The strain Micromonospora marina was isolated from a soft coral and produced a novel depsipeptide compound, namely, thiocoraline (Figure 13, Compound 41). With a MIC value of $0.05 \mu \mathrm{g} / \mathrm{mL}$, thiocoraline exhibited strong antibiotic action against Gram-positive bacterial pathogens, such as B. subtilis, and S. aureus [223].<smiles>C/C=C(\O)[C@H]1[C@@H]([C@@H](C)/C=C\C=C\C(=O)[C@H](C)C(=O)O[C@@H](C)/C=C/C)C=C[C@H]2CC(C)=CC[C@@H]21</smiles>

(38) Anthracimycin<smiles>C[C@@H]1SC(c2ccccc2O)=N[C@H]1[C@H]1SC[C@](C)(C(=O)O)N1C</smiles>

(39) Watasemycin-A<smiles>OC[C@@H]1CSC(c2ccccc2O)=N1</smiles>

(40) Aerugine

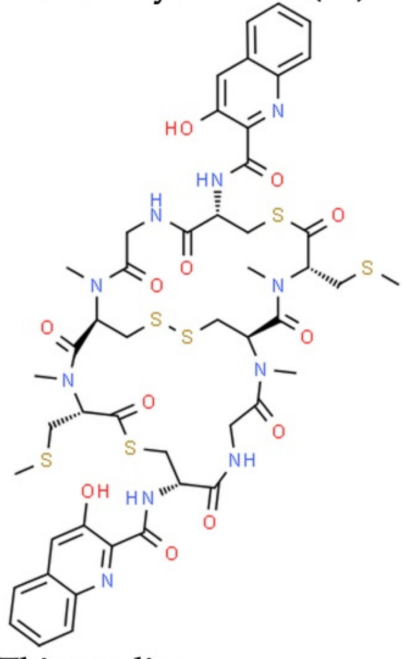

(41) Thiocoraline<smiles>CC[C@H](C)[C@H]1NC(=O)[C@H](C)NC(=O)[C@H](Cc2ccccc2)NC(=O)CNC(=O)[C@H](CC(C)C)NC(=O)[C@H](C(C)C)NC1=O</smiles>

(42) Bacicyclin

Figure 13. Structural representation of antimicrobial compounds 38-42 derived from bacteria associated with marine corals and mollusks.

\subsection{Antimicrobial Potential of Bacteria Associated with Marine Mollusks}

Mollusks are the largest marine phylum, accounting for $23 \%$ of marine organisms. Mollusks with shells are assumed to be low in secondary metabolites, although they may produce peptide toxins for both defense and predation [70]. Secondary metabolites help to protect mollusks even without shells. The systematic structural analysis of certain secondary metabolites has indicated that these small chemical compounds are produced by symbiotic bacteria, not by mollusks [224].

Bacicyclin (Figure 13, Compound 42), a novel cyclic hexapeptide, was identified from Bacillus sp. BC028. This marine bacterial strain was isolated from the common mussel 
(Mytilus edulis). It has antibacterial properties against S. aureus and E. faecalis, with MIC values of 12 and $8 \mu \mathrm{M}$, respectively [225]. S. sampsonii SCSIO 054 is a marine-gastropodmollusk-associated bacteria with a biosynthetic gene cluster that governs the synthesis of the antibacterial compound julichromes [226]. The Hawaiian bobtail squid contains symbiotic bacterial consortia in the auxiliary nidamental gland (a female reproductive system that shields eggs from fouling microorganisms). Nineteen bacterial isolates were isolated from these bacterial consortia. Further, these isolates were tested for their ability to inhibit the growth of Gram-positive and Gram-negative bacterial pathogens. Among these, the two bacterial isolates, Pseudoalteromonas sp. JC28 and Leisingera sp. ANG59, showed potential antibacterial activity against tested bacteria [227].

In addition to these, the antimicrobial activity of numerous bacteria associated with different marine fauna has been extensively documented, as shown in Table 2.

Table 2. Antimicrobial potential of bacteria associated with different marine fauna.

\begin{tabular}{|c|c|c|c|c|c|}
\hline $\begin{array}{l}\text { S. } \\
\text { No }\end{array}$ & Marine Fauna & Associated Marine Bacteria & Secondary Metabolite(s) & Antimicrobial Activity & $\operatorname{Ref}$ \\
\hline 1 & $\begin{array}{l}\text { Sponges } \\
\text { (H. panacea and } \\
\text { Hymeniacidon perlevis) }\end{array}$ & $\begin{array}{l}\text { Maribacter, } \\
\text { Aquimarina, Vagococcus, and } \\
\text { Denitrobaculum bacterial } \\
\text { isolates }\end{array}$ & - & $\begin{array}{l}\text { Exhibited antibacterial activity } \\
\text { against } S \text {. aureus }\end{array}$ & [228] \\
\hline 2 & $\begin{array}{l}\text { Sponges } \\
\text { (Agelas nakamurai and } \\
\text { Aaptos suberitoides) }\end{array}$ & Different Bacillus sp. & Macrolactin A and C14-surfactin & $\begin{array}{l}\text { Inhibited the growth of E. coli } \\
\text { and } M . \text { luteus }\end{array}$ & [229] \\
\hline 3 & Sponge (Suberea mollis) & Vibrio sp. EA348 & Fosfomycin and amifloxacin & $\begin{array}{l}\text { Exhibited antibacterial activity against } \\
\text { both Gram-positive and } \\
\text { Gram-negative bacteria }\end{array}$ & [230] \\
\hline 4 & $\begin{array}{l}\text { Sponges (Demospongiae } \\
\text { and Homoscleromorpha) }\end{array}$ & Genera Vibrio and Bacillus & - & $\begin{array}{l}\text { Inhibited the growth of different } \\
\text { multidrug-resistant bacterial pathogens }\end{array}$ & [231] \\
\hline 5 & $\begin{array}{l}\text { Sponge (Arenosclera } \\
\text { brasiliensis) }\end{array}$ & $\begin{array}{l}\text { Diversity of } \\
\text { heterotrophic bacteria }\end{array}$ & - & $\begin{array}{l}\text { Exhibited antibacterial activity } \\
\text { against } B \text {. subtilis }\end{array}$ & [231] \\
\hline 6 & Sponge (Orina sagittaria) & Actinomycete strain F-04 & Volatile organic compounds & Inhibited growth of S. aureus & [232] \\
\hline 7 & $\begin{array}{l}\text { Coral } \\
\text { (Lophelia pertusa) }\end{array}$ & Streptomyces sp. M-207 & Lobophorin K & $\begin{array}{l}\text { Exhibited antibacterial activity } \\
\text { against } S \text {. aureus }\end{array}$ & [233] \\
\hline 8 & $\begin{array}{l}\text { Coral } \\
\text { (Platygyra sp.) }\end{array}$ & Pseudoalteromonas sp. & $\begin{array}{l}\text { Heat tolerant cell-free culture } \\
\text { supernatant }\end{array}$ & $\begin{array}{l}\text { Inhibited the growth of B. cereus } \\
\text { and S. aureus }\end{array}$ & [234] \\
\hline 9 & Coral (Antipathes dichotoma) & $\begin{array}{l}\text { Three different bacterial phyla } \\
\text { (Actinobacteria, Alphaproteobacteria, } \\
\text { and Firmicutes) }\end{array}$ & - & $\begin{array}{l}\text { Exhibited both antibacterial and } \\
\text { antifungal activities }\end{array}$ & [235] \\
\hline 10 & $\begin{array}{l}\text { Mollusk } \\
\text { (Oysters-Crassostrea gigas) }\end{array}$ & $\begin{array}{l}\text { Pseudoalteromonas } \mathrm{hCg}-6 \\
\text { and } \mathrm{hCg}-42\end{array}$ & Cyclolipopeptides & $\begin{array}{l}\text { Inhibited the growth of Gram-negative } \\
\text { human bacterial pathogens }\end{array}$ & [236] \\
\hline 11 & $\begin{array}{l}\text { Mollusk } \\
\text { (Batillaria zonalis) }\end{array}$ & S. sampsonii SCSIO 054 & Julichrome Monomers & $\begin{array}{l}\text { Inhibited the growth of } S \text {. simulans } \\
\text { and S. aureus }\end{array}$ & [237] \\
\hline 12 & $\begin{array}{l}\text { Mollusk } \\
\text { (Onchidium sp.) }\end{array}$ & S. olivaceus SCSIO LO13 & Borrelidins & $\begin{array}{l}\text { Exhibited antibacterial activity against } \\
\text { both Gram-positive and Gram-negative } \\
\text { bacterial pathogens }\end{array}$ & [238] \\
\hline 13 & $\begin{array}{l}\text { Mollusk (Kuphus } \\
\text { polythalamius) }\end{array}$ & P. aeruginosa 1682U.R.0a.27 & Mindapyrroles A-C & $\begin{array}{l}\text { Showed antibacterial activity against } \\
\text { both Gram-positive and } \\
\text { Gram-negative bacteria }\end{array}$ & [239] \\
\hline 14 & Mollusk (M. edulis) & Bacillus sp. BC028 & Bacicyclin & $\begin{array}{l}\text { Inhibited the growth of clinical } \\
\text { pathogens S. aureus and E. faecalis }\end{array}$ & [225] \\
\hline 15 & Mollusk (Lienardia totopotens) & Streptomyces sp. & Lobophorins & $\begin{array}{l}\text { Inhibited the growth of } M \text {. tuberculosis } \\
\text { and B. cepacia }\end{array}$ & [240] \\
\hline 16 & Mollusk (Anadara broughtoni) & Saccharothrix espanaensis An 113 & Saccharothrixmicines A and B & $\begin{array}{l}\text { Exhibited antifungal activity } \\
\text { against } C \text {. albicans }\end{array}$ & [241] \\
\hline 17 & Mollusk (A. broughtoni) & B. pumilus An 112 & Cyclic depsipeptides & $\begin{array}{l}\text { Exhibited broad spectrum } \\
\text { antibacterial activity }\end{array}$ & [242] \\
\hline 18 & Mollusk (Pecten maximus) & $\begin{array}{l}\text { Bacterial strains CF-20 } \\
\text { and C-148 }\end{array}$ & dd-diketopiperazines & $\begin{array}{l}\text { Exhibited antibacterial activity } \\
\text { against } V \text {. anguillarum }\end{array}$ & [243] \\
\hline
\end{tabular}




\section{Marine Flora}

Like marine fauna, marine flora is also abundant in nature. Some are so tiny and can only be seen with the aid of a microscope. They have various living forms; some float, while others are attached to different surfaces with a holdfast. Organisms in marine flora are rich in minerals and provide nutraceuticals that can be added as the necessary components of the diet. In general, the host-microbe interaction plays a crucial role in host adaptation to different environments [46]. This kind of microbe interaction, especially with plants, results in the production of novel compounds with potential applications in several areas, such as medicine, environmental protection, bioremediation, and others [47]. Hence, the following sections describes the potential antimicrobial compounds from bacteria associated with certain marine flora, such as seaweeds, seagrasses, and mangroves.

\subsection{Antimicrobial Potential of Bacteria Associated with Marine Seaweeds}

Seaweeds (macroalgae) are photosynthetic organisms with an essential role in sustaining the marine ecosystem. Seaweeds are divided into three types based on their pigmentation. They are classified as green algae, brown algae, and red algae. Brown seaweeds contain fucoxanthin and chlorophyll a and c pigments, red seaweeds contain allophycocyanin, phycoerythrin, xanthophylls, and chlorophyll-a pigments, and green seaweeds contain xanthophylls and chlorophyll a and b pigments [244,245]. The seaweed surfaces offer an ideal substrate for microorganisms to colonize, and for various secret organic compounds that serve as nutrients for microorganisms to proliferate. Therefore, they provide an excellent habitat for several microorganisms [246]. Numerous studies have shown that seaweed-associated bacteria are essential for determining the host's basic morphology, growth, and development $[40,76]$. Seaweeds may also be viewed as a source of microbial nutrients, which results in intense competition between diverse microbial populations [66]. Moreover, seaweeds provide nutrients for associated microorganisms which, in turn, defends them from biological threats, such as pathogenic and fouling organisms, via the synthesis and release of bioactive substances [247]. Microbial communities that live on the surfaces of seaweeds are very complex and dynamic, consisting of a diverse array of microorganisms, such as bacteria, fungi, protozoa, and diatoms $[248,249]$. Numerous investigations have shown that bacteria associated with seaweeds are unique from bacteria present in seawater. These bacteria mostly come under the phyla of Actinobacteria, Bacteroidetes, Firmicutes, Planctomycetes, and Proteobacteria [250,251].

A new cyclic tetrapeptide compound, namely, cyclo-[phenylalanyl-prolyl-leucylprolyl] (Figure 14, Compound 43), was identified from marine bacteria Pseudomonas sp. associated with the seaweed (Diginea sp.) that had excellent growth inhibitory potential against $V$. anguillarum and B. subtilis [252]. Franks et al. isolated the marine bacterium $P$. tunicata from the surface of $U$. australis. The antifungal compounds produced by $P$. tunicata provide a competitive edge over marine fungi during surface colonization. Further, tambjamine is a yellow-pigmented chemical molecule from P. tunicate that seems to have antifungal activity $[253,254]$. The novel magnesium-containing antibiotic molecule, magnesidin A (Figure 14, Compound 44), was isolated from the marine bacterium P. magnesiorubra associated with the seaweed Caulerpa peltata. It selectively inhibited the growth of Staphylococcus sp. and Bacillus sp. [255]. Another bioactive compound, namely, 2, 4-diacetylphloroglucinol (Figure 14, Compound 45), was isolated from a novel Pseudomonas sp. AMSA. This surface-associated bacterial strain was isolated from the Ceratodyction spongiosum and significantly hindered S. aureus growth at the concentration of $4 \mathrm{mg} / \mathrm{L}$ [256]. Ravisankar et al. identified an alkaloid compound from Pseudomonas sp. associated with the seaweed Padina tetrastromatica. At a dosage of $300 \mu \mathrm{g}$, this bioactive compound inhibited the growth of Gram-negative bacterial pathogens, such as P. aeruginosa and K. pneumoniae, with an inhibitory zone of 10 and $15 \mathrm{~mm}$, respectively [257]. Pelagiobacter variabilis, a novel marine bacterium, was isolated from the macroalga Pocockiella variegata. This bacterium produces a pelagiomicin A to $C$ series of chemical molecules. Pelagiomicin 
A (Figure 14, Compound 46) showed potent antibacterial activity against a wide range of Gram-positive and Gram-negative bacterial pathogens [258].

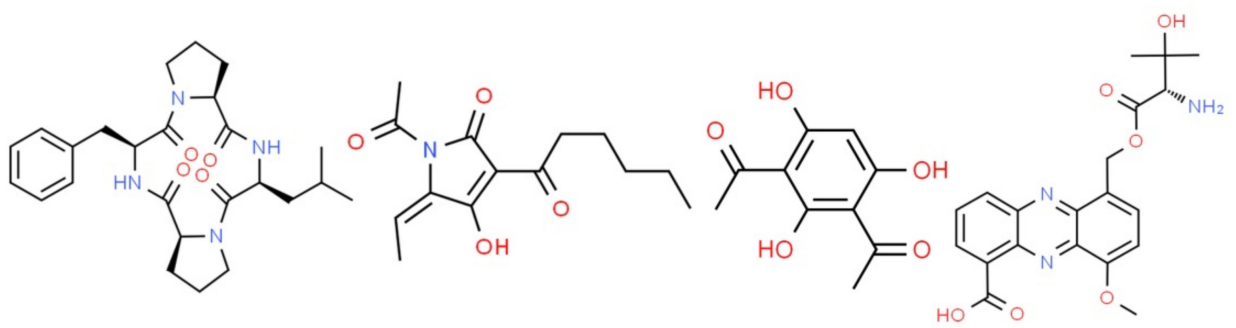

(43) Cyclo-[phenylalanyl- (44) Magnesidin (45) 2, 4-diacetylphloro- (46) Pelagiomicin A
prolyl-leucyl-prolyl]

Figure 14. Structural representation of antimicrobial compounds $43-46$ derived from bacteria associated with marine seaweeds.

\subsection{Antimicrobial Potential of Bacteria Associated with Marine Seagrasses}

Seagrasses provide major habitats for marine microorganisms and have a primary ecological function in coastal regions worldwide. Seagrasses are a diverse species of angiosperms found in the ocean along with macroalgae [259]. Generally, the marine habitat is often used as a nursery by various fish species [260]. The direct contact between animal and plant cells has been shown to promote metabolic pathways in microbes associated with seagrasses. Further, microbiological investigations confirm this theory by demonstrating that the microbial activity of the seagrass-associated holobiont is greater than that of the microbial community grown in a nonvegetated region [251]. Seagrasses have a large proportion of secondary metabolites, such as fatty acids and polyphenols, which are essential for adaptation to biotic and abiotic habitats, as well as the defense mechanism [261]. Moreover, microorganisms associated with seagrasses may preserve their environment by producing bioactive compounds that defend against biological threats, such as pathogenic and fouling organisms. For the same reason, they were recognized as a source of novel bioactive compounds in abundance [262].

A total of 162 rhizome and endophytic bacteria isolates were enumerated from marine seagrass Halodule uninervis collected from the coastal zone of Jeddah, Saudi Arabia. In an in vitro assay, antifungal screening of isolated bacteria showed 19 strains capable of inhibiting the growth of four pathogenic fungi: Rhizoctonia solani, Phytophthora capsici, Pythium ultimum, and Pyricularia oryzae [263]. A recent study reported the isolation and genotypic identification of marine epiphytic bacteria with potent antibacterial activity from the Kuicheai seagrass (H. uninervis). Bacillus, Oceanimonas, Paenibacillus, and Planomicrobium were among the four genera of epiphytic bacteria identified. Using the perpendicular streak technique, Oceanimonas sp. PSS 241 was shown to have effective antibacterial activity against pathogenic S. aureus [264].

\subsection{Antimicrobial Potential of Marine Bacteria Associated with Mangroves}

Mangroves occupy $60-70 \%$ of the world's tropical and subtropical coastlines. This unique environment is a habitat for a diverse array of microorganisms. Microorganisms associated with mangroves may withstand certain changes in physicochemical environments, particularly in high-saline conditions [265]. As a result, they are critical components of this marine ecosystem. Apart from their critical function in ecological balance maintenance and biogeochemical processes, mangrove-associated microbes have a higher biotechnological potential in various fields, including pharmaceutical industries [251]. Marine microorganisms thrive in the lower portion of trunks and the aerating roots of mangrove plants that are permanently or intermittently immersed in saltwater. On the other hand, terrestrial microorganisms are often found in the upper portions of mangrove-aerating roots and trunks [266]. 
The bacteria associated with mangroves, particularly Actinobacteria, are a unique and neglected source of natural pharmaceutical products. There is substantial data from diverse mangrove forests worldwide indicating Actinobacteria's widespread distribution and enormous promise in the pharmaceutical sector [251,267]. The presence of actinomycetes has been well-described in a variety of mangrove environments around the world. In an earlier study, 23 actinomycete species were identified in the Pichavaram mangrove, India, most assigned to the genus Streptomyces [268]. In another study, a total of 518 Streptomyces isolates were identified in mangrove habitats near Porto Novo, India, by Laksmanaperumalsamy et al. [269]. Eccleston et al. revealed the wide spread of actinomycetes belonging to the genus Micromonospora in the mangrove plants of Australia's Sunshine Coast [270]. Similarly, Xie et al. and Huang et al. reported the isolation of a rifamycin-producing Micromonospora from mangroves in the South China Sea [271,272]. Retnowati identified an actinomycete, Streptomyces sp., in mangrove soil on the eastern coast of Surabaya, Indonesia. It inhibited the growth of both Gram-positive and Gramnegative bacterial pathogens [273]. Santhi and Jebakumar reported that Streptomyces sp. isolated from mangrove sediment had profound antibacterial activity against $S$. aureus and Salmonella typhi [274].

Likewise, as shown in Table 3, the antimicrobial activity of several bacteria associated with different marine flora has been comprehensively documented.

Table 3. Antimicrobial potential of bacteria associated with different marine flora.

\begin{tabular}{|c|c|c|c|c|c|}
\hline $\begin{array}{l}\text { S. } \\
\text { No }\end{array}$ & Marine Flora & Associated Marine Bacteria & Secondary Metabolite(s) & Antimicrobial Activity & Ref \\
\hline 1 & $\begin{array}{l}\text { Seaweed } \\
\text { (Gracilaria canaliculata) }\end{array}$ & $\begin{array}{l}\text { Lysinibacillus odysseyi } \\
\text { KC149512 }\end{array}$ & Lupenol, diazene, and furan & $\begin{array}{l}\text { Inhibited the growth of Gram-negative } \\
\text { bacterial pathogens }\end{array}$ & [275] \\
\hline 2 & $\begin{array}{l}\text { Seaweed (Asparagopsis } \\
\text { armata) }\end{array}$ & Shewanella sp. ASP 26 & - & $\begin{array}{l}\text { Showed antibacterial activity against } \\
\text { S. aureus and B. subtilis }\end{array}$ & [276] \\
\hline 3 & $\begin{array}{l}\text { Seaweeds } \\
\text { (U. lactuca, G. corticata, and } \\
\text { Mastophora rosea) }\end{array}$ & $\begin{array}{l}\text { Phyla of Proteobacteria } \\
\text { and Firmicutes }\end{array}$ & $\begin{array}{l}\text { 2-Pyrrolidinone, Phenol, 2, 4-bis } \\
\text { (1,1-dimethylethyl) and } \\
\text { Furan derivatives }\end{array}$ & $\begin{array}{l}\text { Exhibited antibacterial activity against } \\
\text { clinical pathogens }\end{array}$ & [277] \\
\hline 4 & Seaweed (Ulva sp.) & S. althioticus MSM3 & Desertomycin G & $\begin{array}{l}\text { Showed antibacterial activity against a } \\
\text { broad range of Gram-positive } \\
\text { bacterial pathogens }\end{array}$ & [278] \\
\hline 5 & $\begin{array}{l}\text { Seaweed (Anthophycus } \\
\text { longifolius) }\end{array}$ & B. subtilis MTCC 10403 & Aryl-crowned polyketides & $\begin{array}{l}\text { Exhibited antibacterial activity against } \\
\text { different Gram-negative } \\
\text { bacterial pathogens }\end{array}$ & [279] \\
\hline 6 & $\begin{array}{l}\text { Seaweed (Pelvetia } \\
\text { canaliculata) }\end{array}$ & K. marina CMG S2 & Kocumarin & $\begin{array}{l}\text { Inhibited the growth of both bacterial } \\
\text { and fungal pathogens }\end{array}$ & [280] \\
\hline 7 & Seaweed ( $P$. gymnospora) & B. amyloliquefaciens & Polyketides & $\begin{array}{l}\text { Exhibited antibacterial activity against } V \text {. } \\
\text { vulnificus and V. parahaemolyticus }\end{array}$ & [281] \\
\hline 8 & Seaweed (A. longifolius) & B. subtilis MTCC 10403 & Polyketide furanoterpenoids & $\begin{array}{l}\text { Exhibited antibacterial activity against } \\
\text { perceptive food pathogens }\end{array}$ & [282] \\
\hline 9 & $\begin{array}{l}\text { Seaweed } \\
\text { (Sargassum myriocystum) }\end{array}$ & B. subtilis MTCC 10407 & $\begin{array}{l}\text { O-heterocyclic polyketide } \\
\text { derivatives }\end{array}$ & $\begin{array}{l}\text { Showed potent antibacterial activity } \\
\text { against V. parahaemolyticus, Aeromonas } \\
\text { hydrophila, and V. vulnificus }\end{array}$ & [283] \\
\hline 10 & $\begin{array}{l}\text { Seaweed } \\
\text { (Laurenciae papillosa) }\end{array}$ & B. amyloliquefaciens & Polyketides & $\begin{array}{l}\text { Inhibited the growth of } \\
\text { food-borne pathogens }\end{array}$ & [284] \\
\hline 11 & $\begin{array}{l}\text { Seaweed (Rhodophyceae } \\
\text { and Phaeophyceae) }\end{array}$ & $\begin{array}{l}\text { Phyla of Firmicutes and } \\
\text { Proteobacteria }\end{array}$ & Polyketides & Prevented the growth of fouling bacteria & [285] \\
\hline 12 & Seaweed (P. pavonica) & B. pumilus P8 & - & $\begin{array}{l}\text { Exhibited both antibacterial and } \\
\text { antifungal activities }\end{array}$ & [286] \\
\hline 13 & Seaweed (A. longifolius) & B. subtilis MTCC 10403 & $\begin{array}{l}\text { 7-O-methyl-5'-hydroxy-3'- } \\
\text { heptenoate-macrolactin }\end{array}$ & $\begin{array}{l}\text { Exhibited antibacterial activity against } \\
\text { human opportunistic clinical pathogens }\end{array}$ & [287] \\
\hline 14 & $\begin{array}{l}\text { Seaweed } \\
\text { (Fucus serratus) }\end{array}$ & B. licheniformis & YbdN protein & $\begin{array}{l}\text { Inhibited the growth of S. aureus and } \\
\text { Listeria monocytogenes }\end{array}$ & [288] \\
\hline 15 & $\begin{array}{l}\text { Seagrasses (Cymodocea sp., } \\
\text { Enhalus acoroides, } \\
\text { Syringodium sp., and } \\
\text { Thalassia hemprichii) }\end{array}$ & $\begin{array}{l}\text { B. flexus EED } 15 \text { and } \\
\text { S. lienomycini EED } 16\end{array}$ & - & $\begin{array}{l}\text { Inhibited the growth of E. coli } \\
\text { and S. aureus }\end{array}$ & [289] \\
\hline
\end{tabular}


Table 3. Cont.

\begin{tabular}{|c|c|c|c|c|c|}
\hline $\begin{array}{l}\text { S. } \\
\text { No }\end{array}$ & Marine Flora & Associated Marine Bacteria & Secondary Metabolite(s) & Antimicrobial Activity & Ref \\
\hline 16 & $\begin{array}{l}\text { Seagrasses (Cymodocea } \\
\text { serrulata and Syringodium } \\
\text { isoetifolium) }\end{array}$ & $\begin{array}{l}\text { Different endo and } \\
\text { epiphytic bacteria }\end{array}$ & - & $\begin{array}{l}\text { Inhibited the growth of different human } \\
\text { bacterial pathogens }\end{array}$ & [290] \\
\hline 17 & $\begin{array}{l}\text { Mangrove (Rhizophora } \\
\text { mucronata) }\end{array}$ & Rhodococcus sp. & Sterol-glycosides & $\begin{array}{l}\text { Exhibited antibacterial activity against } \\
\text { aquatic bacterial pathogens }\end{array}$ & [291] \\
\hline 18 & Mangroves (Seven different) & $\begin{array}{l}\text { Belongs to the phylum } \\
\text { Gammaproteobacteria }\end{array}$ & - & $\begin{array}{l}\text { Showed antifungal activity against } \\
\text { fungal pathogens }\end{array}$ & [292] \\
\hline 19 & Mangrove (Avicennia marina) & V. parahaemolyticus & Vibriocin & $\begin{array}{l}\text { Used in the management of controlling } \\
\text { the vibrio infections }\end{array}$ & [293] \\
\hline
\end{tabular}

\section{Molecular Approaches for the Identification and Development of Novel Antimicrobial Agents from Marine Bacteria}

Modern advancements in genome sequencing have revealed that microorganisms could produce much more structurally diverse secondary metabolites, owing to several putative biosynthetic gene clusters (BGCs) that encode for secondary metabolites that are not observed under conventional culture conditions [294]. BGCs are composed of a group of genes that collectively code for the synthesis of one or more specific metabolites [295]. These clusters are needed to make a wide range of structurally varied compounds, such as polyketides and nonribosomal peptides. Several methods have been developed in the past decade to trigger these cryptic biosynthetic pathways and stimulate the synthesis of novel secondary metabolites from microorganisms [296]. Polyketide synthases (PKS) and nonribosomal peptide synthases (NRPS) are two examples of complex enzymatic machinery that have been shown to be responsible for the synthesis of marine bacterial bioactive secondary metabolites. Recently, Konstantinou et al. confirmed the potential of sponge-associated Cyanobacteria extracts from various taxonomic groups to produce antibacterial activity against S. aureus [297]. Moreover, they have performed phylogenetic analysis and molecular screening for genes encoding PKS and NRPS on sponge-associated Cyanobacteria. The obtained data reveal that the genes responsible for PKS were more ubiquitous than those responsible for NRPS. Graça et al. performed the molecular and bioactivity assays to evaluate the antimicrobial production of a vast and varied collection of Planctomycetes derived from marine macroalgae. Molecular analysis revealed that 95 percent of derived Planctomycetes contained one or both secondary bioactive genes: the NRPS and PKS genes. Moreover, the bioactivity assays revealed a large number of Planctomycetes (Planctomyces brasiliensis, Rhodopirellula lusitana, R. baltica, and R. rubra) with bioactive extracts that exhibited antibacterial and antifungal activities against $B$. subtilis and C. albicans, respectively [298].

\section{Future Research Directions}

According to scientific evidence, around $2 \%$ of bacteria on Earth can be readily cultivated through a culture-dependent method [299]. There are presently 61 different bacterial phyla identified, 31 of which have no cultivable representatives. Thus, most bacteria are uncultivable and, therefore, the conventional culture techniques always underestimate the richness of diverse bacterial communities [300]. As a result of the development of certain culture-independent methods, there has been a shift toward the characterization of mixed bacterial communities within marine environmental biomass. However, several advanced molecular techniques should be developed for isolating the bacteria from marine environments, which may open new avenues to discovering more structurally unique and effective antimicrobial compounds. The genome study, functional gene screening, and gene manipulation of marine bacteria reveal the potential for producing a wide variety of novel antimicrobial compounds [301-303]. However, only a tiny percentage of the bacterial genes were expressed under certain cultivation states [304]. As a result, distinctive methods should be taken to activate the gene transcription and metabolic reprogramming efficiently. The extraction and characterization of bioactive compounds from marine bacteria are 
challenging since they are produced in small amounts and often mixed forms [67]. As a result, metabolic engineering may need to integrate with natural product drug research for the large-scale manufacturing of the bioactive compounds in marine bacteria.

\section{Concluding Remarks}

Finally, we attempted to examine the trends in scientific publications during the past twenty-five years (1996-2020) in countries engaged in identifying marine bacteria for their antimicrobial potentials. Scientific output in this area has increased rapidly, with the Asian continent leading the way. Moreover, the research organizations in China, India, the USA, South Korea, and Germany have become the top five significant prospectors in identifying antimicrobial-producing marine bacteria (Figure 15). It is clearly shown that the increasing focus of several countries on the identification of structurally unique and effective antimicrobial compounds from marine bacteria may indicate that a large number of new molecules may emerge as possible antimicrobial therapy options in the near future.

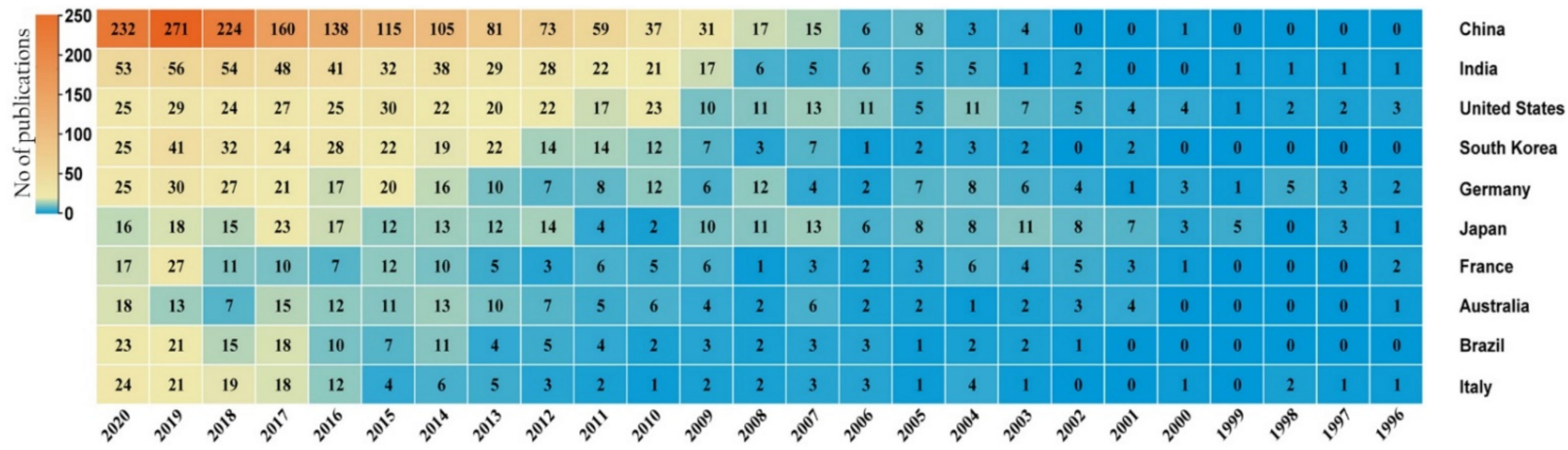

Figure 15. Statistical publication list from top ten countries engaged in studying marine bacteria for their antimicrobial activities. The data were retrieved from the PubMed database (https:/ / pubmed.ncbi.nlm.nih.gov/, accessed on 25 July 2021) by providing the keywords "marine bacteria" and "antimicrobial activity" for the study period (1996-2020).

Overall, developing novel antimicrobial agents, and the alteration of existing drugs obtained from marine bacteria, will be crucial in fighting against microbial resistance. Considering all of the findings and technological advancements made over the past two and half decades, it is evident that marine bacteria will play a crucial role in the future development and trials of structurally unique and effective antimicrobial medicines.

Author Contributions: R.S. and X.L. conceived the concept of the review; R.S. and A.K. drafted the manuscript; R.S. prepared the figures and tables; R.S., A.K., C.S. and X.L. coordinated the work and acquired funding; R.S, A.K. and X.L. reviewed and edited the manuscript. All authors have read and agreed to the published version of the manuscript.

Funding: The authors Ramanathan Srinivasan and Lin Xiangmin thankfully acknowledge the financial support from China Postdoctoral Science Foundation (Grant No. 2019M662214), Natural Science Foundation of China (Grant No. 32171435, 31670129), Program for Innovative Research Team in Fujian Agricultural and Forestry University (Grant No. 712018009), Key Laboratory of Marine Biotechnology of Fujian Province (Grant No. 2020MB04), Key projects of Natural Science Foundation of Fujian Province (Grant No. 2020J02023), and the Fujian-Taiwan Joint Innovative Center for Germplasm Resources and Cultivation of Crop (FJ 2011 Program, Grant No. 2015-75). The authors Arunachalam Kannappan and Chunlei Shi gratefully acknowledge the financial support from the National Key R\&D Program of China (Grant No. 2017YFC1600100) and Natural Science Foundation of China (Grant No. 32001798, 31972169). The structure of all the compounds displayed in this article was retrieved from the ChemSpider database (http:/ / www.chemspider.com/, accessed on 5 September 2021).

Institutional Review Board Statement: Not applicable.

Informed Consent Statement: Not applicable.

Conflicts of Interest: We have no conflict of interest to declare. 


\section{References}

1. Doron, S.; Gorbach, S. Bacterial infections: Overview. Int. Encycl. Public Health 2008, 273-282. [CrossRef]

2. Packiavathy, I.A.S.V.; Kannappan, A.; Thiyagarajan, S.; Srinivasan, R.; Jeyapragash, D.; Paul, J.B.J.; Velmurugan, P.; Ravi, A.V. AHL-Lactonase producing Psychrobacter sp. from Palk Bay sediment mitigates quorum sensing-mediated virulence production in Gram negative bacterial pathogens. Front. Microbiol. 2021, 12, 748. [CrossRef] [PubMed]

3. Cole, L.; Kramer, P.R. Bacteria, virus, fungi, and infectious diseases. Hum. Physiol. Biochem. Basic Med. 2016, 193-196. [CrossRef]

4. Boucher, H.W.; Talbot, G.H.; Bradley, J.S.; Edwards, J.E.; Gilbert, D.; Rice, L.B.; Scheld, M.; Spellberg, B.; Bartlett, J. Bad bugs, no drugs: No ESKAPE! An update from the Infectious Diseases Society of America. Clin. Infect. Dis. 2009, 48, 1-12. [CrossRef]

5. Mulani, M.S.; Kamble, E.E.; Kumkar, S.N.; Tawre, M.S.; Pardesi, K.R. Emerging strategies to combat ESKAPE pathogens in the era of antimicrobial resistance: A review. Front. Microbiol. 2019, 10, 539. [CrossRef]

6. Santajit, S.; Indrawattana, N. Mechanisms of antimicrobial resistance in ESKAPE pathogens. BioMed Res. Int. 2016, $2016,2475067$. [CrossRef] [PubMed]

7. Schultz, F.; Anywar, G.; Tang, H.; Chassagne, F.; Lyles, J.T.; Garbe, L.-A.; Quave, C.L. Targeting ESKAPE pathogens with anti-infective medicinal plants from the Greater Mpigi region in Uganda. Sci. Rep. 2020, 10, 11935. [CrossRef]

8. Brown, G.D.; Denning, D.W.; Gow, N.A.; Levitz, S.M.; Netea, M.G.; White, T.C. Hidden killers: Human fungal infections. Sci. Transl. Med. 2012, 4, 165rv13. [CrossRef]

9. $\quad$ El-Hossary, E.M.; Cheng, C.; Hamed, M.M.; Hamed, A.N.E.-S.; Ohlsen, K.; Hentschel, U.; Abdelmohsen, U.R. Antifungal potential of marine natural products. Eur. J. Med. Chem. 2017, 126, 631-651. [CrossRef] [PubMed]

10. Kullberg, B.J.; Arendrup, M.C. Invasive candidiasis. N. Engl. J. Med. 2015, 373, 1445-1456. [CrossRef]

11. Park, S.J.; Mehrad, B. Innate immunity to Aspergillus species. Clin. Microbiol. Rev. 2009, 22, 535-551. [CrossRef]

12. Dagenais, T.R.; Keller, N.P. Pathogenesis of Aspergillus fumigatus in invasive aspergillosis. Clin. Microbiol. Rev. 2009, $22,447-465$. [CrossRef] [PubMed]

13. Wang, C.; Xiao, X.; Feng, H.; Hong, Z.; Li, M.; Tu, N.; Li, X.; Wang, K.; Bu, L. Ongoing COVID-19 Pandemic: A concise but updated comprehensive review. Curr. Microbiol. 2021, 78, 1718-1729. [CrossRef] [PubMed]

14. Singh, V.; Mishra, V. Environmental impacts of coronavirus disease 2019 (COVID-19). Bioresour. Technol. Rep. 2021, 15, 100744. [CrossRef]

15. Vega, L.E.; Espinoza, L.R. Human immunodeficiency virus infection (HIV)-associated rheumatic manifestations in thepre-and post-HAART eras. Clin. Rheumatol. 2020, 39, 2515-2522. [CrossRef]

16. Walsh, C. Antibiotics: Actions, Origins, Resistance; American Society for Microbiology (ASM): Washington, DC, USA, 2003.

17. Srinivasan, R.; Santhakumari, S.; Poonguzhali, P.; Geetha, M.; Dyavaiah, M.; Lin, X. Bacterial biofilm inhibition: A focused review on recent therapeutic strategies for combating the biofilm mediated infections. Front. Microbiol. 2021, 12, 1106. [CrossRef]

18. Li, Z.; Zhang, L.; Song, Q.; Wang, G.; Yang, W.; Tang, H.; Srinivasan, R.; Lin, L.; Lin, X. Proteomics analysis reveals bacterial antibiotics resistance mechanism mediated by ahslyA against Enoxacin in Aeromonas hydrophila. Front. Microbiol. 2021, $12,1498$.

19. Kannappan, A.; Srinivasan, R.; Nivetha, A.; Annapoorani, A.; Pandian, S.K.; Ravi, A.V. Anti-virulence potential of 2-hydroxy-4methoxybenzaldehyde against methicillin-resistant Staphylococcus aureus and its clinical isolates. Appl. Microbiol. Biotechnol. 2019, 103, 6747-6758. [CrossRef] [PubMed]

20. Kannappan, A.; Sivaranjani, M.; Srinivasan, R.; Rathna, J.; Pandian, S.K.; Ravi, A.V. Inhibitory efficacy of geraniol on biofilm formation and development of adaptive resistance in Staphylococcus epidermidis RP62A. J. Med. Microbiol. 2017, 66, 1506-1515. [CrossRef]

21. Li, Z.; Wang, Y.; Li, X.; Lin, Z.; Lin, Y.; Srinivasan, R.; Lin, X. The characteristics of antibiotic resistance and phenotypes in 29 outer-membrane protein mutant strains in Aeromonas hydrophila. Environ. Microbiol. 2019, 21, 4614-4628. [CrossRef]

22. Podolsky, S.H. The evolving response to antibiotic resistance (1945-2018). Palgrave Commun. 2018, 4, 124. [CrossRef]

23. Alexpandi, R.; Prasanth, M.I.; Ravi, A.V.; Balamurugan, K.; Durgadevi, R.; Srinivasan, R.; De Mesquita, J.F.; Pandian, S.K. Protective effect of neglected plant Diplocyclos palmatus on quorum sensing mediated infection of Serratia marcescens and UV-A induced photoaging in model Caenorhabditis elegans. J. Photochem. Photobiol. B Biol. 2019, 201, 111637. [CrossRef]

24. World Health Organization. Global Antimicrobial Resistance Surveillance System: Manual for Early Implementation; World Health Organization: Geneva, Switzerland, 2015.

25. De Oliveira, D.M.; Forde, B.M.; Kidd, T.J.; Harris, P.N.; Schembri, M.A.; Beatson, S.A.; Paterson, D.L.; Walker, M.J. Antimicrobial resistance in ESKAPE pathogens. Clin. Microbiol. Rev. 2020, 33, e00181-19. [CrossRef] [PubMed]

26. O'Neill, J. Tackling Drug-Resistant Infections Gobally: Final Report and Recommendations-The Review on Antimicrobial Resistance Chaired by Jim O'Neill; Wellcome Trust and HM Government: London, UK, 2016.

27. Fu, Y.; Zhang, L.; Wang, G.; Lin, Y.; Ramanathan, S.; Yang, G.; Lin, W.; Lin, X. The LysR-type transcriptional regulator YeeY plays important roles in the regulatory of furazolidone resistance in Aeromonas hydrophila. Front. Microbiol. 2020, 11, 2208. [CrossRef] [PubMed]

28. Yu, J.; Ramanathan, S.; Chen, L.; Zeng, F.; Li, X.; Zhao, Y.; Lin, L.; Monaghan, S.J.; Lin, X.; Pang, H. Comparative transcriptomic analysis reveals the molecular mechanisms related to oxytetracycline-resistance in strains of Aeromonas hydrophila. Aquac. Rep. 2021, 21, 100812. [CrossRef]

29. Li, W.; Zhao, Y.; Yu, J.; Lin, L.; Ramanathan, S.; Wang, G.; Lin, X.; Pang, H. TonB-dependent receptors affect the spontaneous oxytetracycline resistance evolution in Aeromonas hydrophila. J. Proteome Res. 2020, 20, 154-163. [CrossRef] 
30. Payne, D.J.; Michael, N.; Gwynn, D.J.H.; Pompliano, D.L.; Silver, L.L.; Lomovskaya, O.; Zgurskaya, H.I.; Totrov, M.; Watkins, W.J. The end of an era? Nature 2007, 6, 28.

31. Koehn, F.E.; Carter, G.T. The evolving role of natural products in drug discovery. Nat. Rev. Drug Discov. 2005, 4, 206-220. [CrossRef]

32. Liu, M.; El-Hossary, E.M.; Oelschlaeger, T.A.; Donia, M.S.; Quinn, R.J.; Abdelmohsen, U.R. Potential of marine natural products against drug-resistant bacterial infections. Lancet Infect. Dis. 2019, 19, e237-e245. [CrossRef]

33. Choudhary, A.; Naughton, L.M.; Montánchez, I.; Dobson, A.D.; Rai, D.K. Current status and future prospects of marine natural products (MNPs) as antimicrobials. Mar. Drugs 2017, 15, 272. [CrossRef]

34. Burgess, J.G. New and emerging analytical techniques for marine biotechnology. Curr. Opin. Biotechnol. 2012, 23, 29-33. [CrossRef] [PubMed]

35. Martins, A.; Vieira, H.; Gaspar, H.; Santos, S. Marketed marine natural products in the pharmaceutical and cosmeceutical industries: Tips for success. Mar. Drugs 2014, 12, 1066-1101. [CrossRef]

36. Blunt, J.W.; Copp, B.R.; Munro, M.H.; Northcote, P.T.; Prinsep, M.R. Marine natural products. Nat. Prod. Rep. 2011, 28, 196-268. [CrossRef]

37. Encarnação, T.; Pais, A.A.; Campos, M.G.; Burrows, H.D. Cyanobacteria and microalgae: A renewable source of bioactive compounds and other chemicals. Sci. Prog. 2015, 98, 145-168. [CrossRef]

38. Leal, M.C.; Munro, M.H.; Blunt, J.W.; Puga, J.; Jesus, B.; Calado, R.; Rosa, R.; Madeira, C. Biogeography and biodiscovery hotspots of macroalgal marine natural products. Nat. Prod. Rep. 2013, 30, 1380-1390. [CrossRef]

39. Hegazy, M.E.F.; Mohamed, T.A.; Alhammady, M.A.; Shaheen, A.M.; Reda, E.H.; Elshamy, A.I.; Aziz, M.; Paré, P.W. Molecular architecture and biomedical leads of terpenes from red sea marine invertebrates. Mar. Drugs 2015, 13, 3154-3181. [CrossRef]

40. Singh, R.P.; Kumari, P.; Reddy, C. Antimicrobial compounds from seaweeds-associated bacteria and fungi. Appl. Microbiol. Biotechnol. 2015, 99, 1571-1586. [CrossRef]

41. Hou, X.-M.; Xu, R.-F.; Gu, Y.-C.; Wang, C.-Y.; Shao, C.-L. Biological and chemical diversity of coral-derived microorganisms. Curr. Med. Chem. 2015, 22, 3707-3762. [CrossRef]

42. Srinivasan, R.; Santhakumari, S.; Ravi, A.V. In vitro antibiofilm efficacy of Piper betle against quorum sensing mediated biofilm formation of luminescent Vibrio harveyi. Microb. Pathog. 2017, 110, 232-239. [CrossRef] [PubMed]

43. Srinivasan, R.; Devi, K.R.; Kannappan, A.; Pandian, S.K.; Ravi, A.V. Piper betle and its bioactive metabolite phytol mitigates quorum sensing mediated virulence factors and biofilm of nosocomial pathogen Serratia marcescens in vitro. J. Ethnopharmacol. 2016, 193, 592-603. [CrossRef] [PubMed]

44. Kannappan, A.; Santhakumari, S.; Srinivasan, R.; Pandian, S.K.; Ravi, A.V. Hemidesmus indicus, a traditional medicinal plant, targets the adherence of multidrug-resistant pathogens to form biofilms. Biocatal. Agric. Biotechnol. 2019, 21, 101338. [CrossRef]

45. Kannappan, A.; Gowrishankar, S.; Srinivasan, R.; Pandian, S.K.; Ravi, A.V. Antibiofilm activity of Vetiveria zizanioides root extract against methicillin-resistant Staphylococcus aureus. Microb. Pathog. 2017, 110, 313-324. [CrossRef]

46. Ma, Y. Biotechnological potential of plant-microbe interactions in environmental decontamination. Front. Plant Sci. 2019, 10, 1519. [CrossRef]

47. Fendrihan, S.; Pop, C. Biotechnological potential of plant associated microorganisms. Rom. Biotechnol. Lett. 2021, 26, 2700-2706. [CrossRef]

48. Sivaranjani, M.; Srinivasan, R.; Aravindraja, C.; Karutha Pandian, S.; Veera Ravi, A. Inhibitory effect of $\alpha$-mangostin on Acinetobacter baumannii biofilms-An in vitro study. Biofouling 2018, 34, 579-593. [CrossRef] [PubMed]

49. Ramanathan, S.; Arunachalam, K.; Chandran, S.; Selvaraj, R.; Shunmugiah, K.; Arumugam, V. Biofilm inhibitory efficiency of phytol in combination with cefotaxime against nosocomial pathogen Acinetobacter baumannii. J. Appl. Microbiol. 2018, 125, 56-71. [CrossRef]

50. Srinivasan, R.; Mohankumar, R.; Kannappan, A.; Karthick Raja, V.; Archunan, G.; Karutha Pandian, S.; Ruckmani, K.; Veera Ravi, A. Exploring the anti-quorum sensing and antibiofilm efficacy of phytol against Serratia marcescens associated acute pyelonephritis infection in Wistar rats. Front. Cell. Infect. Microbiol. 2017, 7, 498. [CrossRef]

51. Srinivasan, R.; Devi, K.R.; Santhakumari, S.; Kannappan, A.; Chen, X.; Ravi, A.V.; Lin, X. Anti-quorum sensing and protective efficacies of naringin against Aeromonas hydrophila infection in Danio rerio. Front. Microbiol. 2020, 11, 3087. [CrossRef]

52. Kannappan, A.; Balasubramaniam, B.; Ranjitha, R.; Srinivasan, R.; Packiavathy, I.A.S.V.; Balamurugan, K.; Pandian, S.K.; Ravi, A.V. In vitro and in vivo biofilm inhibitory efficacy of geraniol-cefotaxime combination against Staphylococcus spp. Food Chem. Toxicol. 2019, 125, 322-332. [CrossRef] [PubMed]

53. Taylor, P.L.; Wright, G.D. Novel approaches to discovery of antibacterial agents. Anim. Health Res. Rev. 2008, 9, 237-246. [CrossRef] [PubMed]

54. Fenical, W. Chemical studies of marine bacteria: Developing a new resource. Chem. Rev. 1993, 93, 1673-1683. [CrossRef]

55. Aneiros, A.; Garateix, A. Bioactive peptides from marine sources: Pharmacological properties and isolation procedures. J. Chromatogr. B 2004, 803, 41-53. [CrossRef] [PubMed]

56. Tziveleka, L.-A.; Vagias, C.; Roussis, V. Natural products with anti-HIV activity from marine organisms. Curr. Top. Med. Chem. 2003, 3, 1512-1535. [CrossRef] [PubMed]

57. Gavriilidou, A.; Mackenzie, T.A.; Sánchez, P.; Tormo, J.R.; Ingham, C.; Smidt, H.; Sipkema, D. Bioactivity screening and gene-trait matching across marine sponge-associated bacteria. Mar. Drugs 2021, 19, 75. [CrossRef] [PubMed] 
58. Jaspars, M.; De Pascale, D.; Andersen, J.H.; Reyes, F.; Crawford, A.D.; Ianora, A. The marine biodiscovery pipeline and ocean medicines of tomorrow. J. Mar. Biol. Assoc. UK 2016, 96, 151-158. [CrossRef]

59. Hu, Y.; Chen, J.; Hu, G.; Yu, J.; Zhu, X.; Lin, Y.; Chen, S.; Yuan, J. Statistical research on the bioactivity of new marine natural products discovered during the 28 years from 1985 to 2012. Mar. Drugs 2015, 13, 202-221. [CrossRef] [PubMed]

60. Nalini, S.; Richard, D.S.; Riyaz, S.M.; Kavitha, G.; Inbakandan, D. Antibacterial macro molecules from marine organisms. Int. J. Biol. Macromol. 2018, 115, 696-710. [CrossRef]

61. Abdelmohsen, U.R.; Balasubramanian, S.; Oelschlaeger, T.A.; Grkovic, T.; Pham, N.B.; Quinn, R.J.; Hentschel, U. Potential of marine natural products against drug-resistant fungal, viral, and parasitic infections. Lancet Infect. Dis. 2017, 17, e30-e41. [CrossRef]

62. Fahmy, N.M.; Abdel-Tawab, A.M. Isolation and characterization of marine sponge-associated Streptomyces sp. NMF6 strain producing secondary metabolite (s) possessing antimicrobial, antioxidant, anticancer, and antiviral activities. J. Genet. Eng. Biotechnol. 2021, 19, 102. [CrossRef]

63. Bhatnagar, I.; Kim, S.-K. Immense essence of excellence: Marine microbial bioactive compounds. Mar. Drugs 2010, 8, $2673-2701$. [CrossRef]

64. Laatsch, H. Marine bacterial metabolites. In Frontiers in Marine Biotechnology; Proksch, P., Müller, W.E.G., Eds.; Taylor \& Francis: New York, NY, USA, 2006; Chapter 6.

65. Piel, J. Metabolites from symbiotic bacteria. Nat. Prod. Rep. 2009, 26, 338-362. [CrossRef] [PubMed]

66. Armstrong, E.; Yan, L.; Boyd, K.G.; Wright, P.C.; Burgess, J.G. The symbiotic role of marine microbes on living surfaces. Hydrobiologia 2001, 461, 37-40. [CrossRef]

67. Valliappan, K.; Sun, W.; Li, Z. Marine actinobacteria associated with marine organisms and their potentials in producing pharmaceutical natural products. Appl. Microbiol. Biotechnol. 2014, 98, 7365-7377. [CrossRef]

68. Carroll, A.R.; Copp, B.R.; Davis, R.A.; Keyzers, R.A.; Prinsep, M.R. Marine natural products. Nat. Prod. Rep. 2021, 38, 362-413. [CrossRef] [PubMed]

69. Saurav, K.; Costantino, V.; Venturi, V.; Steindler, L. Quorum sensing inhibitors from the sea discovered using bacterial N-acylhomoserine lactone-based biosensors. Mar. Drugs 2017, 15, 53. [CrossRef] [PubMed]

70. Stincone, P.; Brandelli, A. Marine bacteria as source of antimicrobial compounds. Crit. Rev. Biotechnol. 2020, 40, 306-319. [CrossRef]

71. Núñez-Montero, K.; Barrientos, L. Advances in Antarctic research for antimicrobial discovery: A comprehensive narrative review of bacteria from Antarctic environments as potential sources of novel antibiotic compounds against human pathogens and microorganisms of industrial importance. Antibiotics 2018, 7, 90. [CrossRef] [PubMed]

72. Yasir, M. Analysis of bacterial communities and characterization of antimicrobial strains from cave microbiota. Braz. J. Microbiol. 2018, 49, 248-257. [CrossRef] [PubMed]

73. Kuo, J.; Yang, Y.-T.; Lu, M.-C.; Wong, T.-Y.; Sung, P.-J.; Huang, Y.-S. Antimicrobial activity and diversity of bacteria associated with Taiwanese marine sponge Theonella swinhoei. Ann. Microbiol. 2019, 69, 253-265. [CrossRef]

74. Graça, A.P.; Viana, F.; Bondoso, J.; Correia, M.I.; Gomes, L.; Humanes, M.; Reis, A.; Xavier, J.R.; Gaspar, H.; Lage, O.M. The antimicrobial activity of heterotrophic bacteria isolated from the marine sponge Erylus deficiens (Astrophorida, Geodiidae). Front. Microbiol. 2015, 6, 389.

75. Albakosh, M.A.; Naidoo, R.K.; Kirby, B.; Bauer, R. Identification of epiphytic bacterial communities associated with the brown alga Splachnidium rugosum. J. Appl. Phycol. 2016, 28, 1891-1901. [CrossRef]

76. Bull, A.T.; Stach, J.E. Marine actinobacteria: New opportunities for natural product search and discovery. Trends Microbiol. 2007, 15, 491-499. [CrossRef] [PubMed]

77. Maldonado, L.A.; Stach, J.E.; Pathom-aree, W.; Ward, A.C.; Bull, A.T.; Goodfellow, M. Diversity of cultivable actinobacteria in geographically widespread marine sediments. Antonie Van Leeuwenhoek 2005, 87, 11-18. [CrossRef] [PubMed]

78. Stach, E.; Bull, A.T. Estimating and comparing the diversity of marine actinobacteria. Antonie Van Leeuwenhoek 2005, 87, 3-9. [CrossRef] [PubMed]

79. Jose, P.A.; Jha, B. Intertidal marine sediment harbours Actinobacteria with promising bioactive and biosynthetic potential. Sci. Rep. 2017, 7, 10041. [CrossRef]

80. Montalvo, N.F.; Mohamed, N.M.; Enticknap, J.J.; Hill, R.T. Novel actinobacteria from marine sponges. Antonie Van Leeuwenhoek 2005, 87, 29-36. [CrossRef]

81. Zhang, H.; Lee, Y.K.; Zhang, W.; Lee, H.K. Culturable actinobacteria from the marine sponge Hymeniacidon perleve: Isolation and phylogenetic diversity by 16S rRNA gene-RFLP analysis. Antonie Van Leeuwenhoek 2006, 90, 159-169. [CrossRef]

82. Abdelmohsen, U.R.; Pimentel-Elardo, S.M.; Hanora, A.; Radwan, M.; Abou-El-Ela, S.H.; Ahmed, S.; Hentschel, U. Isolation, phylogenetic analysis and anti-infective activity screening of marine sponge-associated actinomycetes. Mar. Drugs 2010, 8 , 399-412. [CrossRef]

83. Xi, L.; Ruan, J.; Huang, Y. Diversity and biosynthetic potential of culturable actinomycetes associated with marine sponges in the China seas. Int. J. Mol. Sci. 2012, 13, 5917-5932. [CrossRef]

84. Maldonado, L.A.; Fragoso-Yáñez, D.; Pérez-García, A.; Rosellón-Druker, J.; Quintana, E.T. Actinobacterial diversity from marine sediments collected in Mexico. Antonie Van Leeuwenhoek 2009, 95, 111-120. [CrossRef] 
85. Pesic, A.; Baumann, H.I.; Kleinschmidt, K.; Ensle, P.; Wiese, J.; Süssmuth, R.D.; Imhoff, J.F. Champacyclin, a new cyclic octapeptide from Streptomyces strain C42 isolated from the Baltic Sea. Mar. Drugs 2013, 11, 4834-4857. [CrossRef]

86. Contreras-Castro, L.; Martinez-Garcia, S.; Cancino-Diaz, J.C.; Maldonado, L.A.; Hernandez-Guerrero, C.J.; Martínez-Díaz, S.F.; Gonzalez-Acosta, B.; Quintana, E.T. Marine sediment recovered Salinispora sp. inhibits the growth of emerging bacterial pathogens and other multi-drug-resistant bacteria. Pol. J. Microbiol. 2020, 69, 321. [CrossRef] [PubMed]

87. Yücel, S.; Yamaç, M. Selection of Streptomyces isolates from Turkish karstic caves against antibiotic resistant microorganisms. Pak. J. Pharm. Sci 2010, 23, 1-6.

88. Kishimoto, S.; Nishimura, S.; Hattori, A.; Tsujimoto, M.; Hatano, M.; Igarashi, M.; Kakeya, H. Chlorocatechelins A and B from Streptomyces sp.: New siderophores containing chlorinated catecholate groups and an acylguanidine structure. Org. Lett. 2014, 16, 6108-6111. [CrossRef] [PubMed]

89. Ser, H.-L.; Ab Mutalib, N.-S.; Yin, W.-F.; Chan, K.-G.; Goh, B.-H.; Lee, L.-H. Evaluation of antioxidative and cytotoxic activities of Streptomyces pluripotens MUSC 137 isolated from mangrove soil in Malaysia. Front. Microbiol. 2015, 6, 1398. [CrossRef]

90. Lee, L.-H.; Zainal, N.; Azman, A.-S.; Eng, S.-K.; Ab Mutalib, N.-S.; Yin, W.-F.; Chan, K.-G. Streptomyces pluripotens sp. nov., a bacteriocin-producing streptomycete that inhibits meticillin-resistant Staphylococcus aureus. Int. J. Syst. Evol. Microbiol. 2014, 64, 3297-3306. [CrossRef] [PubMed]

91. Sajid, I.; Shaaban, K.A.; Hasnain, S. Identification, isolation and optimization of antifungal metabolites from the Streptomyces Malachitofuscus ctf9. Braz. J. Microbiol. 2011, 42, 592-604. [CrossRef] [PubMed]

92. Fernández-Gomez, B.; Richter, M.; Schüler, M.; Pinhassi, J.; Acinas, S.G.; González, J.M.; Pedros-Alio, C. Ecology of marine Bacteroidetes: A comparative genomics approach. ISME J. 2013, 7, 1026-1037. [CrossRef] [PubMed]

93. Ludwig, W.; Euzéby, J.; Whitman, W. Taxonomic Outline of the Phyla Bacteroidetes, Spirochaetes, Tenericutes (Mollicutes), Acidobacteria, Fibrobacteres, Fusobacteria, Dictyoglomi, Gemmatimonadetes, Lentisphaerae, Verrucomicrobia, Chlamydiae, and Planctomycetes. In Bergey's Manual of Systematic Bacteriology, 2nd ed.; Staley, J.T., Hedlund, B., Paster, B.J., Ward, N., Ludwig, W., Whitman, W.B., Eds.; Springer: Berlin, Germany, 2009; Volume 4.

94. Belizário, J.E.; Napolitano, M. Human microbiomes and their roles in dysbiosis, common diseases, and novel therapeutic approaches. Front. Microbiol. 2015, 6, 1050. [CrossRef] [PubMed]

95. Gavriilidou, A.; Gutleben, J.; Versluis, D.; Forgiarini, F.; Van Passel, M.W.; Ingham, C.J.; Smidt, H.; Sipkema, D. Comparative genomic analysis of Flavobacteriaceae: Insights into carbohydrate metabolism, gliding motility and secondary metabolite biosynthesis. BMC Genom. 2020, 21, 569. [CrossRef]

96. León, J.; Liza, L.; Soto, I.; Torres, M.; Orosco, A. Marine bacteria producing antibacterial compounds isolated from inter-tidal invertebrates. Rev. Peru. Med. Exp. Salud Publ. 2010, 27, 215-221. [CrossRef] [PubMed]

97. Zia, M.A.; Ishaq, M.; Ahmed, I.; Iqbal, H.M.N. Studies on antifungal and antibacterial activity of glucose aero dehydrogenase. World Appl. Sci. J. 2012, 18, 166-170.

98. Tsugawa, W.; Horiuchi, S.; Tanaka, M.; Wake, H.; Sode, K. Purification of a marine bacterial glucose dehydrogenase from Cytophaga marinoflava and its application for measurement of 1, 5-anhydro-D-glucitol. Appl. Biochem. Biotechnol. 1996, 56, 301-310. [CrossRef] [PubMed]

99. Singh, J.S.; Kumar, A.; Rai, A.N.; Singh, D.P. Cyanobacteria: A precious bio-resource in agriculture, ecosystem, and environmental sustainability. Front. Microbiol. 2016, 7, 529. [CrossRef] [PubMed]

100. Tan, L.T. Bioactive natural products from marine cyanobacteria for drug discovery. Phytochemistry 2007, 68, 954-979. [CrossRef] [PubMed]

101. Cardellina, J.H.; Moore, G.E.; Bradley, S. Richard E. Moore (1933-2007); ACS Publications: Washington, DC, USA, 2010.

102. Tidgewell, K.; Clark, B.; Gerwick, W. Comprehensive Natural Products Chemistry; Pergamon Press: Oxford, UK, 2010.

103. Nagarajan, M.; Maruthanayagam, V.; Sundararaman, M. A review of pharmacological and toxicological potentials of marine cyanobacterial metabolites. J. Appl. Toxicol. 2012, 32, 153-185. [CrossRef]

104. Mo, S.; Krunic, A.; Chlipala, G.; Orjala, J. Antimicrobial ambiguine isonitriles from the cyanobacterium Fischerella ambigua. J. Nat. Prod. 2009, 72, 894-899. [CrossRef]

105. Brumley, D.; Spencer, K.A.; Gunasekera, S.P.; Sauvage, T.; Biggs, J.; Paul, V.J.; Luesch, H. Isolation and characterization of anaephenes A-C, alkylphenols from a filamentous cyanobacterium (Hormoscilla sp., oscillatoriales). J. Nat. Prod. 2018, 81, 2716-2721. [CrossRef] [PubMed]

106. Reshef, V.; Mizrachi, E.; Maretzki, T.; Silberstein, C.; Loya, S.; Hizi, A.; Carmeli, S. New acylated sulfoglycolipids and digalactolipids and related known glycolipids from cyanobacteria with a potential to inhibit the reverse transcriptase of HIV-1. J. Nat. Prod. 1997, 60, 1251-1260. [CrossRef]

107. Gordon, D.M.; Danishefsky, S.J. Synthesis of a cyanobacterial sulfolipid: Confirmation of its structure, stereochemistry and anti-HIV-1 activity. J. Am. Chem. Soc. 1992, 114, 659-663. [CrossRef]

108. Loya, S.; Reshef, V.; Mizrachi, E.; Silberstein, C.; Rachamim, Y.; Carmeli, S.; Hizi, A. The inhibition of the reverse transcriptase of HIV-1 by the natural sulfoglycolipids from cyanobacteria: Contribution of different moieties to their high potency. J. Nat. Prod. 1998, 61, 891-895. [CrossRef]

109. Gustafson, K.R.; Cardellina, J.H.; Fuller, R.W.; Weislow, O.S.; Kiser, R.F.; Snader, K.M.; Patterson, G.M.; Boyd, M.R. AIDS-antiviral sulfolipids from cyanobacteria (blue-green algae). JNCI J. Natl. Cancer Inst. 1989, 81, 1254-1258. [CrossRef] [PubMed] 
110. Ayehunie, S.; Belay, A.; Baba, T.W.; Ruprecht, R.M. Inhibition of HIV-1 replication by an aqueous extract of Spirulina platensis (Arthrospira platensis). J. Acquir. Immune Defic. Syndr. Hum. Retrovirol. 1998, 18, 7-12. [CrossRef] [PubMed]

111. Hayashi, T.; Hayashi, K.; Maeda, M.; Kojima, I. Calcium spirulan, an inhibitor of enveloped virus replication, from a blue-green alga Spirulina platensis. J. Nat. Prod. 1996, 59, 83-87. [CrossRef] [PubMed]

112. Boyd, M.R.; Gustafson, K.R.; McMahon, J.B.; Shoemaker, R.H.; O’Keefe, B.R.; Mori, T.; Gulakowski, R.J.; Wu, L.; Rivera, M.I.; Laurencot, C.M. Discovery of cyanovirin-N, a novel human immunodeficiency virus-inactivating protein that binds viral surface envelope glycoprotein gp120: Potential applications to microbicide development. Antimicrob. Agents Chemother. 1997, 41, 1521-1530. [CrossRef]

113. Ntougias, S.; Russell, N.J. Bacillus sp. WW3-SN6, a novel facultatively alkaliphilic bacterium isolated from the washwaters of edible olives. Extremophiles 2000, 4, 201-208. [CrossRef]

114. Rossi, M.; Ciaramella, M.; Cannio, R.; Pisani, F.M.; Moracci, M.; Bartolucci, S. Extremophiles 2002. J. Bacteriol. 2003, 185, 3683-3689. [CrossRef]

115. Nair, A.V.; Praveen, N.; Joseph, N.; Leo, A.M.; Vijayan, K. Isolation and characterization of a novel antimicrobial oxatetracyclo ketone from Bacillus stercoris MBTDCMFRI Ba37 isolated from the tropical estuarine habitats of Cochin. Mol. Biol. Rep. 2021, 48, 1299-1310. [CrossRef]

116. Vairagkar, U.; Mirza, Y. Antagonistic activity of antimicrobial metabolites produced from seaweed-associated Bacillus amyloliquefaciens MTCC 10456 Against Malassezia spp. Probiot. Antimicrob. Proteins 2021, 13, 1228-1237. [CrossRef]

117. Wang, W.; Park, K.-H.; Lee, J.; Oh, E.; Park, C.; Kang, E.; Lee, J.; Kang, H. A new thiopeptide antibiotic, Micrococcin P3, from a marine-derived strain of the bacterium Bacillus stratosphericus. Molecules 2020, 25, 4383. [CrossRef]

118. Fuerst, J.A.; Sagulenko, E. Beyond the bacterium: Planctomycetes challenge our concepts of microbial structure and function. Nat. Rev. Microbiol. 2011, 9, 403-413. [CrossRef] [PubMed]

119. Sandargo, B.; Jeske, O.; Boedeker, C.; Wiegand, S.; Wennrich, J.-P.; Kallscheuer, N.; Jogler, M.; Rohde, M.; Jogler, C.; Surup, F. Stieleriacines, $\mathrm{N}$-acyl dehydrotyrosines from the marine planctomycete Stieleria neptunia sp. nov. Front. Microbiol. 2020, $11,1408$. [CrossRef]

120. Jeske, O.; Jogler, M.; Petersen, J.; Sikorski, J.; Jogler, C. From genome mining to phenotypic microarrays: Planctomycetes as source for novel bioactive molecules. Antonie Van Leeuwenhoek 2013, 104, 551-567. [CrossRef] [PubMed]

121. Jeske, O.; Surup, F.; Ketteniß, M.; Rast, P.; Förster, B.; Jogler, M.; Wink, J.; Jogler, C. Developing techniques for the utilization of Planctomycetes as producers of bioactive molecules. Front. Microbiol. 2016, 7, 1242. [CrossRef]

122. Kallscheuer, N.; Jeske, O.; Sandargo, B.; Boedeker, C.; Wiegand, S.; Bartling, P.; Jogler, M.; Rohde, M.; Petersen, J.; Medema, M.H. The planctomycete Stieleria maiorica Mal15 T employs stieleriacines to alter the species composition in marine biofilms. Commun. Biol. 2020, 3, 303. [CrossRef]

123. Liao, L.; Xu, X.-W.; Wang, C.-S.; Zhang, D.-S.; Wu, M. Bacterial and archaeal communities in the surface sediment from the northern slope of the South China Sea. J. Zhejiang Univ. Sci. B 2009, 10, 890-901. [CrossRef] [PubMed]

124. Kai, W.; Peisheng, Y.; Rui, M.; Wenwen, J.; Zongze, S. Diversity of culturable bacteria in deep-sea water from the South Atlantic Ocean. Bioengineered 2017, 8, 572-584. [CrossRef]

125. Viju, N.; Punitha, S.M.J.; Satheesh, S. An analysis of biosynthesis gene clusters and bioactivity of marine bacterial symbionts. Curr. Microbiol. 2021, 78, 2522-2533. [CrossRef]

126. Bowman, J.P. Bioactive compound synthetic capacity and ecological significance of marine bacterial genus Pseudoalteromonas. Mar. Drugs 2007, 5, 220-241. [CrossRef] [PubMed]

127. Dat, T.T.H.; Cuc, N.T.K.; Cuong, P.V.; Smidt, H.; Sipkema, D. Diversity and antimicrobial activity of Vietnamese sponge-associated bacteria. Mar. Drugs 2021, 19, 353. [CrossRef] [PubMed]

128. Fenical, W.; Jensen, P.R. Developing a new resource for drug discovery: Marine actinomycete bacteria. Nat. Chem. Biol. 2006, 2, 666-673. [CrossRef]

129. Habbu, P.; Warad, V.; Shastri, R.; Madagundi, S.; Kulkarni, V.H. Antimicrobial metabolites from marine microorganisms. Chin. J. Nat. Med. 2016, 14, 101-116. [CrossRef]

130. You, J.; Cao, L.; Liu, G.; Zhou, S.; Tan, H.; Lin, Y. Isolation and characterization of actinomycetes antagonistic to pathogenic Vibrio spp. from nearshore marine sediments. World J. Microbiol. Biotechnol. 2005, 21, 679-682. [CrossRef]

131. Asolkar, R.N.; Maskey, R.P.; Helmke, E.; Laatsch, H. Chalcomycin B, a new macrolide antibiotic from the marine isolate Streptomyces sp. B7064. J. Antibiot. 2002, 55, 893-898. [CrossRef] [PubMed]

132. Shao, M.; Ma, J.; Li, Q.; Ju, J. Identification of the anti-infective aborycin biosynthetic gene cluster from deep-sea-derived Streptomyces sp. SCSIO ZS0098 enables production in a heterologous host. Mar. Drugs 2019, 17, 127. [CrossRef]

133. Zhang, J.; Li, B.; Qin, Y.; Karthik, L.; Zhu, G.; Hou, C.; Jiang, L.; Liu, M.; Ye, X.; Liu, M. A new abyssomicin polyketide with anti-influenza A virus activity from a marine-derived Verrucosispora sp. MS100137. Appl. Microbiol. Biotechnol. 2020, 104, 1533-1543. [CrossRef] [PubMed]

134. Grossart, H.-P.; Thorwest, M.; Plitzko, I.; Brinkhoff, T.; Simon, M.; Zeeck, A. Production of a blue pigment (Glaukothalin) by marine Rheinheimera spp. Int. J. Microbiol. 2009, 2009, 701735. [CrossRef]

135. Soliev, A.B.; Hosokawa, K.; Enomoto, K. Bioactive pigments from marine bacteria: Applications and physiological roles. Evid.-Based Complement. Altern. Med. 2011, 2011, 670349. [CrossRef] [PubMed]

136. Boger, D.L.; Patel, M. Total synthesis of prodigiosin. Tetrahedron Lett. 1987, 28, 2499-2502. [CrossRef] 
137. Gandhi, N.; Patell, J.; Gandhi, J.; De Souza, N.; Kohl, H. Prodigiosin metabolites of a marine Pseudomonas species. Mar. Biol. 1976, 34, 223-227. [CrossRef]

138. Gauthier, M. Alteromonas rubra sp. nov., a new marine antibiotic-producing bacterium. Int. J. Syst. Evol. Microbiol. 1976, 26, 459-466. [CrossRef]

139. Lewis, S.; Corpe, W. Prodigiosin-producing bacteria from marine sources. Appl. Microbiol. 1964, 12, 13-17. [CrossRef] [PubMed]

140. Nakashima, T.; Kurachi, M.; Kato, Y.; Yamaguchi, K.; Oda, T. Characterization of bacterium isolated from the sediment at coastal area of Omura Bay in Japan and several biological activities of pigment produced by this isolate. Microbiol. Immunol. 2005, 49, 407-415. [CrossRef]

141. Le, T.C.; Yang, I.; Yoon, Y.J.; Nam, S.-J.; Fenical, W. Ansalactams B-D illustrate further biosynthetic plasticity within the ansamycin pathway. Org. Lett. 2016, 18, 2256-2259. [CrossRef] [PubMed]

142. Hong, W.Y.; Jun, Y.S.; Yu, S.J.; Mei, Z.L.; Hong, L. Recent advances in study on cyclic peptides from marine sponges. Chin. J. Org. Chem. 2001, 21, 16-24.

143. Xu, X.; Han, J.; Lin, R.; Polyak, S.W.; Song, F. Two new piperazine-triones from a marine-derived Streptomycetes sp. strain SMS636. Mar. Drugs 2019, 17, 186. [CrossRef]

144. Engelhardt, K.; Degnes, K.F.; Kemmler, M.; Bredholt, H.; Fjærvik, E.; Klinkenberg, G.; Sletta, H.; Ellingsen, T.E.; Zotchev, S.B. Production of a new thiopeptide antibiotic, TP-1161, by a marine Nocardiopsis species. Appl. Environ. Microbiol. 2010, 76, 4969-4976. [CrossRef] [PubMed]

145. Sun, P.; Maloney, K.N.; Nam, S.-J.; Haste, N.M.; Raju, R.; Aalbersberg, W.; Jensen, P.R.; Nizet, V.; Hensler, M.E.; Fenical, W. Fijimycins A-C, three antibacterial etamycin-class depsipeptides from a marine-derived Streptomyces sp. Bioorg. Med. Chem. 2011, 19, 6557-6562. [CrossRef]

146. Bertrand, S.; Bohni, N.; Schnee, S.; Schumpp, O.; Gindro, K.; Wolfender, J.-L. Metabolite induction via microorganism co-culture: A potential way to enhance chemical diversity for drug discovery. Biotechnol. Adv. 2014, 32, 1180-1204. [CrossRef]

147. Anjum, K.; Sadiq, I.; Chen, L.; Kaleem, S.; Li, X.-C.; Zhang, Z.; Lian, X.-Y. Novel antifungal janthinopolyenemycins A and B from a co-culture of marine-associated Janthinobacterium spp. ZZ145 and ZZ148. Tetrahedron Lett. 2018, 59, 3490-3494. [CrossRef]

148. Cho, J.Y.; Kim, M.S. Induction of antifouling diterpene production by Streptomyces cinnabarinus PK209 in co-culture with marine-derived Alteromonas sp. KNS-16. Biosci. Biotechnol. Biochem. 2012, 76, 1849-1854. [CrossRef]

149. Oku, N.; Kawabata, K.; Adachi, K.; Katsuta, A.; Shizuri, Y. Unnarmicins A and C, new antibacterial depsipeptides produced by marine bacterium Photobacterium sp. MBIC06485. J. Antibiot. 2008, 61, 11-17. [CrossRef] [PubMed]

150. Braña, A.F.; Sarmiento-Vizcaíno, A.; Pérez-Victoria, I.; Otero, L.; Fernández, J.; Palacios, J.J.; Martín, J.S.; De la Cruz, M.; Díaz, C.; Vicente, F. Branimycins B and C, antibiotics produced by the abyssal actinobacterium Pseudonocardia carboxydivorans M-227. J. Nat. Prod. 2017, 80, 569-573. [CrossRef] [PubMed]

151. Lee, D.-S.; Eom, S.-H.; Jeong, S.-Y.; Shin, H.J.; Je, J.-Y.; Lee, E.-W.; Chung, Y.-H.; Kim, Y.-M.; Kang, C.-K.; Lee, M.-S. Anti-methicillinresistant Staphylococcus aureus (MRSA) substance from the marine bacterium Pseudomonas sp. UJ-6. Environ. Toxicol. Pharmacol. 2013, 35, 171-177. [CrossRef] [PubMed]

152. Furumai, T.; Takagi, K.; Igarashi, Y.; Saito, N.; Oki, T. Arisostatins A and B, new members of tetrocarcin class of antibiotics from Micromonospora sp. TP-A0316 I. Taxonomy, fermentation, isolation and biological properties. J. Antibiot. 2000, 53, 227-232. [CrossRef] [PubMed]

153. Arena, A.; Maugeri, T.L.; Pavone, B.; Iannello, D.; Gugliandolo, C.; Bisignano, G. Antiviral and immunoregulatory effect of a novel exopolysaccharide from a marine thermotolerant Bacillus licheniformis. Int. Immunopharmacol. 2006, 6, 8-13. [CrossRef]

154. Arena, A.; Gugliandolo, C.; Stassi, G.; Pavone, B.; Iannello, D.; Bisignano, G.; Maugeri, T.L. An exopolysaccharide produced by Geobacillus thermodenitrificans strain B3-72: Antiviral activity on immunocompetent cells. Immunol. Lett. 2009, 123, 132-137. [CrossRef]

155. Igarashi, M.; Sawa, R.; Umekita, M.; Hatano, M.; Arisaka, R.; Hayashi, C.; Ishizaki, Y.; Suzuki, M.; Kato, C. Sealutomicins, new enediyne antibiotics from the deep-sea actinomycete Nonomuraea sp. MM565M-173N2. J. Antibiot. 2021, 74, 291-299. [CrossRef] [PubMed]

156. Ribeiro, I.; Girão, M.; Alexandrino, D.A.; Ribeiro, T.; Santos, C.; Pereira, F.; Mucha, A.P.; Urbatzka, R.; Leão, P.N.; Carvalho, M.F. Diversity and bioactive potential of actinobacteria isolated from a coastal marine sediment in northern Portugal. Microorganisms 2020, 8, 1691. [CrossRef] [PubMed]

157. Sangkanu, S.; Rukachaisirikul, V.; Suriyachadkun, C.; Phongpaichit, S. Antifungal activity of marine-derived actinomycetes against Talaromyces marneffei. J. Appl. Microbiol. 2021, 130, 1508-1522. [CrossRef] [PubMed]

158. Yi, W.; Qin, L.; Lian, X.-Y.; Zhang, Z. New antifungal metabolites from the mariana trench sediment-associated actinomycete Streptomyces sp. SY1965. Mar. Drugs 2020, 18, 385. [CrossRef]

159. Ma, Z.; Zhang, S.; Zhang, S.; Wu, G.; Shao, Y.; Mi, Q.; Liang, J.; Sun, K.; Hu, J. Isolation and characterization of a new cyclic lipopeptide surfactin from a marine-derived Bacillus velezensis SH-B74. J. Antibiot. 2020, 73, 863-867. [CrossRef] [PubMed]

160. Liu, K.; Ding, H.; Yu, Y.; Chen, B. A cold-adapted chitinase-producing bacterium from Antarctica and its potential in biocontrol of plant pathogenic fungi. Mar. Drugs 2019, 17, 695. [CrossRef]

161. Choi, A.; Nam, Y.H.; Baek, K.; Chung, E.J. Brevibacillus antibioticus sp. nov., with a broad range of antibacterial activity, isolated from soil in the Nakdong River. J. Microbiol. 2019, 57, 991-996. [CrossRef] [PubMed] 
162. Siddharth, S. Isolation and characterization of bioactive compounds with antibacterial, antioxidant and enzyme inhibitory activities from marine-derived rare actinobacteria, Nocardiopsis sp. SCA21. Microb. Pathog. 2019, 137, 103775. [CrossRef] [PubMed]

163. Da Silva, A.B.; Pinto, F.C.; Silveira, E.R.; Costa-Lotufo, L.V.; Costa, W.S.; Ayala, A.P.; Canuto, K.M.; Barros, A.B.; Araújo, A.J.; Marinho Filho, J.D.B. 4-Hydroxy-pyran-2-one and 3-hydroxy-N-methyl-2-oxindole derivatives of Salinispora arenicola from Brazilian marine sediments. Fitoterapia 2019, 138, 104357. [CrossRef]

164. Almalki, M.A. Isolation and characterization of polyketide drug molecule from Streptomyces species with antimicrobial activity against clinical pathogens. J. Infect. Public Health 2020, 13, 125-130. [CrossRef] [PubMed]

165. Da Silva, A.B.; Silveira, E.R.; Wilke, D.V.; Ferreira, E.G.; Costa-Lotufo, L.V.; Torres, M.C.M.; Ayala, A.P.; Costa, W.S.; Canuto, K.M.; De Araujo-Nobre, A.R. Antibacterial Salinaphthoquinones from a strain of the bacterium Salinispora arenicola recovered from the marine sediments of St. Peter and St. Paul Archipelago, Brazil. J. Nat. Prod. 2019, 82, 1831-1838. [CrossRef]

166. Ryu, M.-J.; Hwang, S.; Kim, S.; Yang, I.; Oh, D.-C.; Nam, S.-J.; Fenical, W. Meroindenon and merochlorins E and F, antibacterial meroterpenoids from a marine-derived sediment bacterium of the genus Streptomyces. Org. Lett. 2019, 21, 5779-5783. [CrossRef]

167. Sproule, A.; Correa, H.; Decken, A.; Haltli, B.; Berrué, F.; Overy, D.P.; Kerr, R.G. Terrosamycins A and B, bioactive polyether ionophores from Streptomyces sp. RKND004 from Prince Edward Island sediment. Mar. Drugs 2019, 17, 347. [CrossRef]

168. Gozari, M.; Zaheri, A.; Jahromi, S.T.; Gozari, M.; Karimzadeh, R. Screening and characterization of marine actinomycetes from the northern Oman Sea sediments for cytotoxic and antimicrobial activity. Int. Microbiol. 2019, 22, 521-530. [CrossRef]

169. De Oliveira, J.A.M.; Williams, D.E.; Andersen, R.J.; Sarragiotto, M.H.; Baldoqui, D.C. Mycenolide A, new butenolide from a marine sediment-derived bacterium Streptomyces sp. 4054. Nat. Prod. Res. 2020, 34, 2986-2989. [CrossRef]

170. Zhang, S.; Gui, C.; Shao, M.; Kumar, P.S.; Huang, H.; Ju, J. Antimicrobial tunicamycin derivatives from the deep sea-derived Streptomyces xinghaiensis SCSIO S15077. Nat. Prod. Res. 2020, 34, 1499-1504. [CrossRef] [PubMed]

171. Galaviz-Silva, L.; Iracheta-Villarreal, J.M.; Molina-Garza, Z.J. Bacillus and Virgibacillus strains isolated from three Mexican coasts antagonize Staphylococcus aureus and Vibrio parahaemolyticus. FEMS Microbiol. Lett. 2018, 365, fny202. [CrossRef] [PubMed]

172. Priyanka, S.; Jayashree, M.; Shivani, R.; Anwesha, S.; Rao, K.B. Characterisation and identification of antibacterial compound from marine actinobacteria: In vitro and in silico analysis. J. Infect. Public Health 2019, 12, 83-89. [CrossRef]

173. Quintero, M.; Velásquez, A.; Jutinico, L.; Jiménez-Vergara, E.; Blandón, L.; Martinez, K.; Lee, H.; Gómez-León, J. Bioprospecting from marine coastal sediments of Colombian Caribbean: Screening and study of antimicrobial activity. J. Appl. Microbiol. 2018, 125, 753-765. [CrossRef]

174. Hamed, A.; Abdel-Razek, A.S.; Frese, M.; Wibberg, D.; El-Haddad, A.F.; Ibrahim, T.M.; Kalinowski, J.; Sewald, N.; Shaaban, M. N-Acetylborrelidin B: A new bioactive metabolite from Streptomyces mutabilis sp. MII. Z. Nat. C 2018, 73, 49-57. [CrossRef]

175. Sangkanu, S.; Rukachaisirikul, V.; Suriyachadkun, C.; Phongpaichit, S. Evaluation of antibacterial potential of mangrove sediment-derived actinomycetes. Microb. Pathog. 2017, 112, 303-312. [CrossRef] [PubMed]

176. Arumugam, T.; Kumar, P.S.; Kameshwar, R.; Prapanchana, K. Screening of novel actinobacteria and characterization of the potential isolates from mangrove sediment of south coastal India. Microb. Pathog. 2017, 107, 225-233. [CrossRef] [PubMed]

177. Kurata, A.; Yamaura, Y.; Tanaka, T.; Kato, C.; Nakasone, K.; Kishimoto, N. Antifungal peptidic compound from the deep-sea bacterium Aneurinibacillus sp. YR247. World J. Microbiol. Biotechnol. 2017, 33, 73. [CrossRef] [PubMed]

178. Kalinovskaya, N.; Romanenko, L.; Kalinovsky, A. Antibacterial low-molecular-weight compounds produced by the marine bacterium Rheinheimera japonica KMM 9513. Antonie Van Leeuwenhoek 2017, 110, 719-726. [CrossRef]

179. Anand, B.G.; Thomas, C.N.; Prakash, S. In vitro cytotoxicity and antimicrobial activity of Talaromyces flavus SP5 inhabited in the marine sediment of Southern Coast of India. Chin. J. Nat. Med. 2016, 14, 913-921. [CrossRef]

180. Baskaran, R.; Mohan, P.; Sivakumar, K.; Kumar, A. Antimicrobial activity and phylogenetic analysis of Streptomyces parvulus DOSMB-D105 isolated from the mangrove sediments of Andaman Islands. Acta Microbiol. Immunol. Hungar. 2016, 63, 27-46. [CrossRef] [PubMed]

181. Romanenko, L.; Tanaka, N.; Svetashev, V.; Kalinovskaya, N.; Mikhailov, V. Rheinheimera japonica sp. nov., a novel bacterium with antimicrobial activity from seashore sediments of the Sea of Japan. Arch. Microbiol. 2015, 197, 613-620. [CrossRef]

182. Raju, R.; Khalil, Z.G.; Piggott, A.M.; Blumenthal, A.; Gardiner, D.L.; Skinner-Adams, T.S.; Capon, R.J. Mollemycin A: An antimalarial and antibacterial glyco-hexadepsipeptide-polyketide from an Australian marine-derived Streptomyces sp. (CMBM0244). Org. Lett. 2014, 16, 1716-1719. [CrossRef]

183. Chopra, L.; Singh, G.; Choudhary, V.; Sahoo, D.K. Sonorensin: An antimicrobial peptide, belonging to the heterocycloanthracin subfamily of bacteriocins, from a new marine isolate, Bacillus sonorensis MT93. Appl. Environ. Microbiol. 2014, 80, 2981-2990. [CrossRef] [PubMed]

184. Sletta, H.; Degnes, K.F.; Herfindal, L.; Klinkenberg, G.; Fjærvik, E.; Zahlsen, K.; Brunsvik, A.; Nygaard, G.; Aachmann, F.L.; Ellingsen, T.E. Anti-microbial and cytotoxic 1, 6-dihydroxyphenazine-5, 10-dioxide (iodinin) produced by Streptosporangium sp. DSM 45942 isolated from the fjord sediment. Appl. Microbiol. Biotechnol. 2014, 98, 603-610. [CrossRef] [PubMed]

185. Pan, H.-Q.; Zhang, S.-Y.; Wang, N.; Li, Z.-L.; Hua, H.-M.; Hu, J.-C.; Wang, S.-J. New spirotetronate antibiotics, lobophorins H and I, from a South China Sea-derived Streptomyces sp. 12A35. Mar. Drugs 2013, 11, 3891-3901. [CrossRef] [PubMed]

186. Sato, S.; Iwata, F.; Yamada, S.; Katayama, M. Neomaclafungins A-I: Oligomycin-class macrolides from a marine-derived actinomycete. J. Nat. Prod. 2012, 75, 1974-1982. [CrossRef] [PubMed] 
187. Li, S.; Tian, X.; Niu, S.; Zhang, W.; Chen, Y.; Zhang, H.; Yang, X.; Zhang, W.; Li, W.; Zhang, S. Pseudonocardians A-C, new diazaanthraquinone derivatives from a deap-sea actinomycete Pseudonocardia sp. SCSIO 01299. Mar. Drugs 2011, 9, 1428-1439. [CrossRef]

188. Hohmann, C.; Schneider, K.; Bruntner, C.; Irran, E.; Nicholson, G.; Bull, A.T.; Jones, A.L.; Brown, R.; Stach, J.E.; Goodfellow, M. Caboxamycin, a new antibiotic of the benzoxazole family produced by the deep-sea strain Streptomyces sp. NTK 937. J. Antibiot. 2009, 62, 99-104. [CrossRef]

189. Ren, Z.-Z.; Zheng, Y.; Sun, M.; Liu, J.-Z.; Wang, Y.-J. Purification and properties of an antimicrobial substance from marine Brevibacillus laterosporus Lh-1. Acta Microbiol. Sin. 2007, 47, 997-1001.

190. Schumacher, R.W.; Talmage, S.C.; Miller, S.A.; Sarris, K.E.; Davidson, B.S.; Goldberg, A. Isolation and structure determination of an antimicrobial ester from a marine sediment-derived bacterium. J. Nat. Prod. 2003, 66, 1291-1293. [CrossRef] [PubMed]

191. Huang, H.; Song, Y.; Li, X.; Wang, X.; Ling, C.; Qin, X.; Zhou, Z.; Li, Q.; Wei, X.; Ju, J. Abyssomicin monomers and dimers from the marine-derived Streptomyces koyangensis SCSIO 5802. J. Nat. Prod. 2018, 81, 1892-1898. [CrossRef] [PubMed]

192. Kim, S.-H.; Ha, T.-K.-Q.; Oh, W.K.; Shin, J.; Oh, D.-C. Antiviral indolosesquiterpenoid xiamycins C-E from a halophilic actinomycete. J. Nat. Prod. 2016, 79, 51-58. [CrossRef]

193. Uzair, B.; Bano, A.; Niazi, M.B.K.; Khan, F.; Mujtaba, G. In vitro antifungal activity of 9, 10-dihydrophenanthrene-2-carboxylic acid isolated from a marine bacterium: Pseudomonas putida. Pak. J. Pharm. Sci. 2018, 31, 2733-2736.

194. Harounabadi, S.; Shamsabad, P.E.; Mostafavi, S.K.S.; Meybodi, S.M. Isolation and partial characterization of bacteria with potential antimicrobial activity from the Caspian Sea. Russ. J. Mar. Biol. 2016, 42, 36-41. [CrossRef]

195. Sannino, F.; Parrilli, E.; Apuzzo, G.A.; De Pascale, D.; Tedesco, P.; Maida, I.; Perrin, E.; Fondi, M.; Fani, R.; Marino, G. Pseudoalteromonas haloplanktis produces methylamine, a volatile compound active against Burkholderia cepacia complex strains. New Biotechnol. 2017, 35, 13-18. [CrossRef]

196. Jayme, M.M.A.; Castro, R.O.; Silva, C.A.M.; Silva, M.M.; Do Carmo, F.L.; De Araujo, F.V. Evaluation of the biotechnological potential of bacterioplankton from Niterói coast, RJ. Compt. Rendus Biol. 2017, 340, 324-329. [CrossRef]

197. Taylor, M.W.; Radax, R.; Steger, D.; Wagner, M. Sponge-associated microorganisms: Evolution, ecology, and biotechnological potential. Microbiol. Mol. Biol. Rev. 2007, 71, 295-347. [CrossRef] [PubMed]

198. Sagar, S.; Kaur, M.; Minneman, K.P. Antiviral lead compounds from marine sponges. Mar. Drugs 2010, 8, 2619-2638. [CrossRef] [PubMed]

199. Wagner-Döbler, I.; Beil, W.; Lang, S.; Meiners, M.; Laatsch, H. Integrated approach to explore the potential of marine microorganisms for the production of bioactive metabolites. Tools Appl. Biochem. Eng. Sci. 2002, 74, 207-238.

200. Thoms, C.; Schupp, P. Biotechnological Potential of Marine Sponges and Their Associated Bacteria as Producers of New Pharmaceuticals (Part II); Walter de Gruyter: Berlin, Germany, 2005.

201. Bibi, F.; Naseer, M.I.; Azhar, E.I. Assessing the diversity of bacterial communities from marine sponges and their bioactive compounds. Saudi J. Biol. Sci. 2021, 28, 2747-2754. [CrossRef]

202. Altuğ, G.; Türetken, P.S.Ç.; Kalkan, S.; Topaloğlu, B. The distribution and antibacterial activity of marine sponge-associated bacteria in the Aegean Sea and the Sea of Marmara, Turkey. Curr. Microbiol. 2021, 78, 2275-2290. [CrossRef] [PubMed]

203. Abdelmohsen, U.R.; Bayer, K.; Hentschel, U. Diversity, abundance and natural products of marine sponge-associated actinomycetes. Nat. Prod. Rep. 2014, 31, 381-399. [CrossRef]

204. Khan, S.T.; Komaki, H.; Motohashi, K.; Kozone, I.; Mukai, A.; Takagi, M.; Shin-ya, K. Streptomyces associated with a marine sponge Haliclona sp.; biosynthetic genes for secondary metabolites and products. Environ. Microbiol. 2011, 13, 391-403. [CrossRef]

205. Balasubramanian, S.; Othman, E.M.; Kampik, D.; Stopper, H.; Hentschel, U.; Ziebuhr, W.; Oelschlaeger, T.A.; Abdelmohsen, U.R. Marine sponge-derived Streptomyces sp. SBT343 extract inhibits staphylococcal biofilm formation. Front. Microbiol. 2017, 8, 236. [CrossRef]

206. Abdelmohsen, U.R.; Zhang, G.; Philippe, A.; Schmitz, W.; Pimentel-Elardo, S.M.; Hertlein-Amslinger, B.; Hentschel, U.; Bringmann, G. Cyclodysidins A-D, cyclic lipopeptides from the marine sponge-derived Streptomyces strain RV15. Tetrahedron Lett. 2012, 53, 23-29. [CrossRef]

207. Lin, S.-C.; Lehman, C.W.; Stewart, A.K.; Panny, L.; Bracci, N.; Wright, J.L.; Paige, M.; Strangman, W.K.; Kehn-Hall, K. Homoseongomycin, a compound isolated from marine actinomycete bacteria K3-1, is a potent inhibitor of encephalitic alphaviruses. Antivir. Res. 2021, 191, 105087. [CrossRef]

208. Mitova, M.; Popov, S.; De Rosa, S. Cyclic peptides from a Ruegeria strain of bacteria associated with the sponge Suberites domuncula. J. Nat. Prod. 2004, 67, 1178-1181. [CrossRef]

209. Nagai, K.; Kamigiri, K.; Arao, N.; Suzumura, K.-I.; Kawano, Y.; Yamaoka, M.; Zhang, H.; Watanabe, M.; Suzuki, K. YM-266183 and ym-266184, novel thiopeptide antibiotics produced by Bacillus cereus isolated from a marine sponge i. taxonomy, fermentation, isolation, physico-chemical properties and biological properties. J. Antibiot. 2003, 56, 123-128. [CrossRef] [PubMed]

210. Martín, J.; Sousa, D.S.; Crespo, G.; Palomo, S.; González, I.; Tormo, J.R.; De la Cruz, M.; Anderson, M.; Hill, R.T.; Vicente, F. Kocurin, the true structure of PM181104, an anti-methicillin-resistant Staphylococcus aureus (MRSA) thiazolyl peptide from the marine-derived bacterium Kocuria palustris. Mar. Drugs 2013, 11, 387-398. [CrossRef] [PubMed]

211. Adnani, N.; Chevrette, M.G.; Adibhatla, S.N.; Zhang, F.; Yu, Q.; Braun, D.R.; Nelson, J.; Simpkins, S.W.; McDonald, B.R.; Myers, C.L. Coculture of marine invertebrate-associated bacteria and interdisciplinary technologies enable biosynthesis and discovery of a new antibiotic, keyicin. ACS Chem. Biol. 2017, 12, 3093-3102. [CrossRef] [PubMed] 
212. Yu, M.; Li, Y.; Banakar, S.P.; Liu, L.; Shao, C.; Li, Z.; Wang, C. New metabolites from the co-culture of marine-derived actinomycete Streptomyces rochei MB037 and fungus Rhinocladiella similis 35. Front. Microbiol. 2019, 10, 915. [CrossRef]

213. Dashti, Y.; Grkovic, T.; Abdelmohsen, U.R.; Hentschel, U.; Quinn, R.J. Production of induced secondary metabolites by a co-culture of sponge-associated actinomycetes, Actinokineospora sp. EG49 and Nocardiopsis sp. RV163. Mar. Drugs 2014, 12, 3046-3059. [CrossRef]

214. Wu, Q.; Sun, J.; Chen, J.; Zhang, H.; Guo, Y.-W.; Wang, H. Terpenoids from marine soft coral of the genus Lemnalia: Chemistry and biological activities. Mar. Drugs 2018, 16, 320. [CrossRef]

215. Webster, N.S.; Reusch, T.B. Microbial contributions to the persistence of coral reefs. ISME J. 2017, 11, 2167-2174. [CrossRef]

216. Rosenberg, E.; Koren, O.; Reshef, L.; Efrony, R.; Zilber-Rosenberg, I. The role of microorganisms in coral health, disease and evolution. Nat. Rev. Microbiol. 2007, 5, 355-362. [CrossRef]

217. Alagely, A.; Krediet, C.J.; Ritchie, K.B.; Teplitski, M. Signaling-mediated cross-talk modulates swarming and biofilm formation in a coral pathogen Serratia marcescens. ISME J. 2011, 5, 1609-1620. [CrossRef] [PubMed]

218. Ritchie, K.B. Regulation of microbial populations by coral surface mucus and mucus-associated bacteria. Mar. Ecol. Prog. Ser. 2006, 322, 1-14. [CrossRef]

219. Shnit-Orland, M.; Kushmaro, A. Coral mucus-associated bacteria: A possible first line of defense. FEMS Microbiol. Ecol. 2009, 67, 371-380. [CrossRef] [PubMed]

220. Rodríguez, V.; Martín, J.; Sarmiento-Vizcaíno, A.; De la Cruz, M.; García, L.A.; Blanco, G.; Reyes, F. Anthracimycin B, a potent antibiotic against Gram-positive bacteria isolated from cultures of the deep-sea actinomycete Streptomyces cyaneofuscatus M-169. Mar. Drugs 2018, 16, 406. [CrossRef]

221. Fu, P.; Kong, F.; Wang, Y.; Wang, Y.; Liu, P.; Zuo, G.; Zhu, W. Antibiotic metabolites from the coral-associated Actinomycete Streptomyces sp. OUCMDZ-1703. Chin. J. Chem. 2013, 31, 100-104. [CrossRef]

222. Sarmiento-Vizcaíno, A.; González, V.; Braña, A.F.; Palacios, J.J.; Otero, L.; Fernández, J.; Molina, A.; Kulik, A.; Vázquez, F.; Acuña, J.L. Pharmacological potential of phylogenetically diverse Actinobacteria isolated from deep-sea coral ecosystems of the submarine Avilés Canyon in the Cantabrian Sea. Microb. Ecol. 2017, 73, 338-352. [CrossRef] [PubMed]

223. Romero, F.; Espliego, F.; Baz, J.P.; De Quesada, T.G.; Gravalos, D.; De La Calle, F.; Fernandez-puentes, J.L. Thiocoraline, a new depsipeptide with antitumor activity produced by a marine Micromonospora I. Taxonomy, fermentation, isolation, and biological activities. J. Antibiot. 1997, 50, 734-737. [CrossRef] [PubMed]

224. Benkendorff, K. Molluscan biological and chemical diversity: Secondary metabolites and medicinal resources produced by marine molluscs. Biol. Rev. 2010, 85, 757-775. [CrossRef]

225. Wiese, J.; Abdelmohsen, U.R.; Motiei, A.; Humeida, U.H.; Imhoff, J.F. Bacicyclin, a new antibacterial cyclic hexapeptide from Bacillus sp. strain BC028 isolated from Mytilus edulis. Bioorg. Med. Chem. Lett. 2018, 28, 558-561. [CrossRef] [PubMed]

226. Ji, X.; Dong, Y.; Ling, C.; Zhou, Z.; Li, Q.; Ju, J. Elucidation of the tailoring steps in Julichrome biosynthesis by marine gastropod mollusk-associated Streptomyces sampsonii SCSIO 054. Org. Lett. 2020, 22, 6927-6931. [CrossRef] [PubMed]

227. Suria, A.M.; Tan, K.C.; Kerwin, A.H.; Gitzel, L.; Abini-Agbomson, L.; Bertenshaw, J.M.; Sewell, J.; Nyholm, S.V.; Balunas, M.J. Hawaiian bobtail squid symbionts inhibit marine bacteria via production of specialized metabolites, including new bromoalterochromides BAC-D/D'. Msphere 2020, 5, e00166-20. [CrossRef] [PubMed]

228. Rodriguez Jimenez, A.; Dechamps, E.; Giaux, A.; Goetghebuer, L.; Bauwens, M.; Willenz, P.; Flahaut, S.; Laport, M.S.; George, I.F. The sponges Hymeniacidon perlevis and Halichondria panicea are reservoirs of antibiotic-producing bacteria against multi-drug resistant Staphylococcus aureus. J. Appl. Microbiol. 2021, 131, 706-718. [CrossRef]

229. Balansa, W.; Liu, Y.; Sharma, A.; Mihajlovic, S.; Hartwig, C.; Leis, B.; Rieuwpassa, F.J.; Ijong, F.G.; Wägele, H.; König, G.M. Selection of sponge-associated bacteria with high potential for the production of antibacterial compounds. Sci. Rep. 2020, 10, 19614.

230. Bibi, F.; Yasir, M.; Al-Sofyani, A.; Naseer, M.I.; Azhar, E.I. Antimicrobial activity of bacteria from marine sponge Suberea mollis and bioactive metabolites of Vibrio sp. EA348. Saudi J. Biol. Sci. 2020, 27, 1139-1147. [CrossRef]

231. Freitas-Silva, J.; Silva-Oliveira, T.; Muricy, G.; Laport, M.S. Bacillus strains associated to homoscleromorpha sponges are highly active against multidrug resistant bacteria. Curr. Microbiol. 2020, 77, 807-815. [CrossRef]

232. Rajasabapathy, R.; Ghadi, S.C.; Manikandan, B.; Mohandass, C.; Surendran, A.; Dastager, S.G.; Meena, R.M.; James, R.A. Antimicrobial profiling of coral reef and sponge associated bacteria from southeast coast of India. Microb. Pathog. 2020, 141, 103972. [CrossRef]

233. Braña, A.F.; Sarmiento-Vizcaíno, A.; Osset, M.; Pérez-Victoria, I.; Martín, J.; De Pedro, N.; De la Cruz, M.; Díaz, C.; Vicente, F.; Reyes, F. Lobophorin K, a new natural product with cytotoxic activity produced by Streptomyces sp. M-207 associated with the deep-sea coral Lophelia pertusa. Mar. Drugs 2017, 15, 144. [CrossRef] [PubMed]

234. Shnit-Orland, M.; Sivan, A.; Kushmaro, A. Antibacterial activity of Pseudoalteromonas in the coral holobiont. Microb. Ecol. 2012, 64, 851-859. [CrossRef]

235. Zhang, X.; Sun, Y.; Bao, J.; He, F.; Xu, X.; Qi, S. Phylogenetic survey and antimicrobial activity of culturable microorganisms associated with the South China Sea black coral Antipathes dichotoma. FEMS Microbiol. Lett. 2012, 336, 122-130. [CrossRef]

236. Desriac, F.; El Harras, A.; Simon, M.; Bondon, A.; Brillet, B.; Le Chevalier, P.; Pugnière, M.; Got, P.; Destoumieux-Garzon, D.; Fleury, Y. Alterins produced by oyster-associated Pseudoalteromonas are antibacterial cyclolipopeptides with LPS-binding activity. Mar. Drugs 2020, 18, 630. [CrossRef] 
237. Dong, Y.; Ding, W.; Sun, C.; Ji, X.; Ling, C.; Zhou, Z.; Chen, Z.; Chen, X.; Ju, J. Julichrome monomers from marine gastropod mollusk-associated Streptomyces and stereochemical revision of Julichromes Q3·5 and Q3·3. Chem. Biodivers. 2020, 17, e2000057. [PubMed]

238. Zhou, Z.; Wu, Q.; Xie, Q.; Ling, C.; Zhang, H.; Sun, C.; Ju, J. New borrelidins from Onchidium sp. associated Streptomyces olivaceus SCSIO LO13. Chem. Biodivers. 2020, 17, e1900560. [CrossRef] [PubMed]

239. Lacerna, N.M.; Miller, B.W.; Lim, A.L.; Tun, J.O.; Robes, J.M.D.; Cleofas, M.J.B.; Lin, Z.; Salvador-Reyes, L.A.; Haygood, M.G.; Schmidt, E.W. Mindapyrroles A-C, pyoluteorin analogues from a shipworm-associated bacterium. J. Nat. Prod. 2019, 82, 1024-1028. [CrossRef] [PubMed]

240. Lin, Z.; Koch, M.; Pond, C.D.; Mabeza, G.; Seronay, R.A.; Concepcion, G.P.; Barrows, L.R.; Olivera, B.M.; Schmidt, E.W. Structure and activity of lobophorins from a turrid mollusk-associated Streptomyces sp. J. Antibiot. 2014, 67, 121-126. [CrossRef] [PubMed]

241. Kalinovskaya, N.I.; Kalinovsky, A.I.; Romanenko, L.A.; Dmitrenok, P.S.; Kuznetsova, T.A. New angucyclines and antimicrobial diketopiperazines from the marine mollusk-derived actinomycete Saccharothrix espanaensis An 113. Nat. Prod. Commun. 2010, 5, 1934578X1000500420. [CrossRef]

242. Romanenko, L.A.; Uchino, M.; Kalinovskaya, N.I.; Mikhailov, V.V. Isolation, phylogenetic analysis and screening of marine mollusc-associated bacteria for antimicrobial, hemolytic and surface activities. Microbiol. Res. 2008, 163, 633-644. [CrossRef]

243. Fdhila, F.; Vázquez, V.; Sánchez, J.L.; Riguera, R. DD-Diketopiperazines: Antibiotics active against Vibrio a nguillarum isolated from marine bacteria associated with cultures of Pecten maximus. J. Nat. Prod. 2003, 66, 1299-1301. [CrossRef] [PubMed]

244. Norziah, M.H.; Ching, C.Y. Nutritional composition of edible seaweed Gracilaria changgi. Food Chem. 2000, 68, 69-76. [CrossRef]

245. Aryee, A.N.; Agyei, D.; Akanbi, T.O. Recovery and utilization of seaweed pigments in food processing. Curr. Opin. Food Sci. 2018, 19, 113-119. [CrossRef]

246. Singh, R.P.; Reddy, C. Seaweed-microbial interactions: Key functions of seaweed-associated bacteria. FEMS Microbiol. Ecol. 2014, 88, 213-230. [CrossRef]

247. Menaa, F.; Wijesinghe, P.; Thiripuranathar, G.; Uzair, B.; Iqbal, H.; Khan, B.A.; Menaa, B. Ecological and industrial implications of dynamic seaweed-associated microbiota interactions. Mar. Drugs 2020, 18, 641. [CrossRef] [PubMed]

248. Lachnit, T.; Meske, D.; Wahl, M.; Harder, T.; Schmitz, R. Epibacterial community patterns on marine macroalgae are host-specific but temporally variable. Environ. Microbiol. 2011, 13, 655-665. [CrossRef] [PubMed]

249. Burke, C.; Thomas, T.; Lewis, M.; Steinberg, P.; Kjelleberg, S. Composition, uniqueness and variability of the epiphytic bacterial community of the green alga Ulva australis. ISME J. 2011, 5, 590-600. [CrossRef] [PubMed]

250. Hollants, J.; Leliaert, F.; Verbruggen, H.; Willems, A.; De Clerck, O. Permanent residents or temporary lodgers: Characterizing intracellular bacterial communities in the siphonous green alga Bryopsis. Proc. R. Soc. B Biol. Sci. 2013, 280, 20122659. [CrossRef] [PubMed]

251. Gozari, M.; Alborz, M.; El-Seedi, H.R.; Jassbi, A.R. Chemistry, biosynthesis and biological activity of terpenoids and meroterpenoids in bacteria and fungi isolated from different marine habitats. Eur. J. Med. Chem. 2020, 210, 112957. [CrossRef] [PubMed]

252. Rungprom, W.; Siwu, E.R.; Lambert, L.K.; Dechsakulwatana, C.; Barden, M.C.; Kokpol, U.; Blanchfield, J.T.; Kita, M.; Garson, M.J. Cyclic tetrapeptides from marine bacteria associated with the seaweed Diginea sp. and the sponge Halisarca ectofibrosa. Tetrahedron 2008, 64, 3147-3152. [CrossRef]

253. Franks, A.; Haywood, P.; Holmström, C.; Egan, S.; Kjelleberg, S.; Kumar, N. Isolation and structure elucidation of a novel yellow pigment from the marine bacterium Pseudoalteromonas tunicata. Molecules 2005, 10, 1286-1291. [CrossRef]

254. Franks, A.; Egan, S.; Holmström, C.; James, S.; Lappin-Scott, H.; Kjelleberg, S. Inhibition of fungal colonization by Pseudoalteromonas tunicata provides a competitive advantage during surface colonization. Appl. Environ. Microbiol. 2006, 72, 6079-6087. [CrossRef]

255. Gandhi, N.; Nazareth, J.; Divekar, P.; Kohl, H.; De Souza, N. Magnesidin, a novel magnesium-containing antibiotic. J. Antibiot. 1973, 26, 797-798. [CrossRef]

256. Isnansetyo, A.; Horikawa, M.; Kamei, Y. In vitro anti-methicillin-resistant Staphylococcus aureus activity of 2, 4-diacetylphloroglucinol produced by Pseudomonas sp. AMSN isolated from a marine alga. J. Antimicrob. Chemother. 2001, 47, 724-725. [CrossRef]

257. Ravisankar, A.; Gnanambal, M.E.K.; Sundaram, L.R. A newly isolated Pseudomonas sp., epibiotic on the seaweed, Padina tetrastromatica, off Southeastern Coast of India, reveals antibacterial action. Appl. Biochem. Biotechnol. 2013, 171, $1968-1985$. [CrossRef]

258. Imamura, N.; Nishijima, M.; Takadera, T.; Adachi, K.; SAKAI, M.; Sano, H. New anticancer antibiotics pelagiomicins, produced by a new marine bacterium Pelagiobacter variabilis. J. Antibiot. 1997, 50, 8-12. [CrossRef]

259. Short, F.T.; Polidoro, B.; Livingstone, S.R.; Carpenter, K.E.; Bandeira, S.; Bujang, J.S.; Calumpong, H.P.; Carruthers, T.J.; Coles, R.G.; Dennison, W.C. Extinction risk assessment of the world's seagrass species. Biol. Conserv. 2011, 144, 1961-1971. [CrossRef]

260. Bertelli, C.M.; Unsworth, R.K. Protecting the hand that feeds us: Seagrass (Zostera marina) serves as commercial juvenile fish habitat. Mar. Pollut. Bull. 2014, 83, 425-429. [CrossRef]

261. Custódio, L.; Laukaityte, S.; Engelen, A.H.; Rodrigues, M.J.; Pereira, H.; Vizetto-Duarte, C.; Barreira, L.; Rodríguez, H.; Alberício, F.; Varela, J. A comparative evaluation of biological activities and bioactive compounds of the seagrasses Zostera marina and Zostera noltei from southern Portugal. Nat. Prod. Res. 2016, 30, 724-728. [CrossRef] 
262. Rotter, A.; Barbier, M.; Bertoni, F.; Bones, A.M.; Cancela, M.L.; Carlsson, J.; Carvalho, M.F.; Cegłowska, M.; Chirivella-Martorell, J.; Conk Dalay, M. The essentials of marine biotechnology. Front. Mar. Sci. 2021, 8, 158. [CrossRef]

263. Bibi, F.; Naseer, M.I.; Hassan, A.M.; Yasir, M.; Al-Ghamdi, A.A.K.; Azhar, E.I. Diversity and antagonistic potential of bacteria isolated from marine grass Halodule uninervis. 3 Biotech 2018, 8, 48. [CrossRef] [PubMed]

264. Boontanom, P.; Chantarasiri, A. Diversity of culturable epiphytic bacteria isolated from seagrass (Halodule uninervis) in Thailand and their preliminary antibacterial activity. Biodiversitas J. Biol. Divers. 2020, 21, 7. [CrossRef]

265. Thatoi, H.; Biswal, A. Mangroves of Orissa Coast: Floral diversity and conservation status. Spec. Habit. Threaten. Plants India ENVIS Wild Life Protect. Area 2008, 11, 201-207.

266. Sarma, V.; Hyde, K.D. A review on frequently occurring fungi in mangroves. Fungal Divers. 2001, 8, 1-34.

267. Hong, K.; Gao, A.-H.; Xie, Q.-Y.; Gao, H.G.; Zhuang, L.; Lin, H.-P.; Yu, H.-P.; Li, J.; Yao, X.-S.; Goodfellow, M. Actinomycetes for marine drug discovery isolated from mangrove soils and plants in China. Mar. Drugs 2009, 7, 24-44. [CrossRef] [PubMed]

268. Sivakumar, K. Actinomycetes of an Indian Mangrove (Pitchavaram) Environment; an Inventory. Ph.D. Thesis, Annamalai University, Annamalai Nagar, India, 2001.

269. Laksmanaperumalsamy, P.; Chandramohan, D.; Natarajan, R. Antibacterial and antifungal activity of streptomycetes from Porto Novo coastal environment. Mar. Biol. 1978, 11, 15-24.

270. Eccleston, G.P.; Brooks, P.R.; Kurtböke, D.I. The occurrence of bioactive micromonosporae in aquatic habitats of the Sunshine Coast in Australia. Mar. Drugs 2008, 6, 243-261. [CrossRef]

271. Huang, H.; Lv, J.; Hu, Y.; Fang, Z.; Zhang, K.; Bao, S. Micromonospora rifamycinica sp. nov., a novel actinomycete from mangrove sediment. Int. J. Syst. Evol. Microbiol. 2008, 58, 17-20. [CrossRef]

272. Xie, X.-C.; Mei, W.-L.; Zhao, Y.-X.; Hong, K.; Dai, H.-F. A new degraded sesquiterpene from marine actinomycete Streptomyces sp. 0616208. Chin. Chem. Lett. 2006, 17, 1463-1465.

273. Retnowati, W. Identification of Streptomyces sp-MWS1 producing antibacterial compounds. Indones. J. Trop. Infect. Dis. 2010, 1, 82-85. [CrossRef]

274. Satheeja, S.V.; Jebakumar, S.R. Phylogenetic analysis and antimicrobial activities of Streptomyces isolates from mangrove sediment. J. Basic Microbiol. 2011, 51, 71-79. [CrossRef]

275. Karthick, P.; Mohanraju, R. Antimicrobial compounds produced by Lysinibacillus odysseyi epiphytic bacteria associated with red algae. Braz. J. Microbiol. 2020, 51, 1683-1690. [CrossRef] [PubMed]

276. Horta, A.; Alves, C.; Pinteus, S.; Lopes, C.; Fino, N.; Silva, J.; Ribeiro, J.; Rodrigues, D.; Francisco, J.; Rodrigues, A. Identification of Asparagopsis armata-associated bacteria and characterization of their bioactive potential. Microbiol. Open 2019, 8, e00824. [CrossRef] [PubMed]

277. Karthick, P.; Mohanraju, R. Antimicrobial potential of epiphytic bacteria associated with seaweeds of Little Andaman, India. Front. Microbiol. 2018, 9, 611. [CrossRef] [PubMed]

278. Braña, A.F.; Sarmiento-Vizcaíno, A.; Pérez-Victoria, I.; Martín, J.; Otero, L.; Palacios-Gutiérrez, J.J.; Fernández, J.; Mohamedi, Y.; Fontanil, T.; Salmón, M. Desertomycin G, a new antibiotic with activity against Mycobacterium tuberculosis and human breast tumor cell lines produced by Streptomyces althioticus MSM3, isolated from the Cantabrian Sea Intertidal macroalgae Ulva sp. Mar. Drugs 2019, 17, 114. [CrossRef] [PubMed]

279. Chakraborty, K.; Thilakan, B.; Kizhakkekalam, V. Antibacterial aryl-crowned polyketide from Bacillus subtilis associated with seaweed Anthophycus longifolius. J. Appl. Microbiol. 2018, 124, 108-125. [CrossRef] [PubMed]

280. Uzair, B.; Menaa, F.; Khan, B.A.; Mohammad, F.V.; Ahmad, V.U.; Djeribi, R.; Menaa, B. Isolation, purification, structural elucidation and antimicrobial activities of kocumarin, a novel antibiotic isolated from actinobacterium Kocuria marina CMG S2 associated with the brown seaweed Pelvetia canaliculata. Microbiol. Res. 2018, 206, 186-197. [CrossRef]

281. Chakraborty, K.; Thilakan, B.; Raola, V.K. Previously undescribed antibacterial polyketides from heterotrophic Bacillus amyloliquefaciens associated with seaweed Padina gymnospora. Appl. Biochem. Biotechnol. 2018, 184, 716-732. [CrossRef] [PubMed]

282. Chakraborty, K.; Thilakan, B.; Raola, V.K. Antimicrobial polyketide furanoterpenoids from seaweed-associated heterotrophic bacterium Bacillus subtilis MTCC 10403. Phytochemistry 2017, 142, 112-125. [CrossRef] [PubMed]

283. Chakraborty, K.; Thilakan, B.; Chakraborty, R.D.; Raola, V.K.; Joy, M. O-heterocyclic derivatives with antibacterial properties from marine bacterium Bacillus subtilis associated with seaweed, Sargassum myriocystum. Appl. Microbiol. Biotechnol. 2017, 101, 569-583. [CrossRef] [PubMed]

284. Chakraborty, K.; Thilakan, B.; Raola, V.K.; Joy, M. Antibacterial polyketides from Bacillus amyloliquefaciens associated with edible red seaweed Laurenciae papillosa. Food Chem. 2017, 218, 427-434. [CrossRef]

285. Thilakan, B.; Chakraborty, K.; Chakraborty, R.D. Antimicrobial properties of cultivable bacteria associated with seaweeds in the Gulf of Mannar on the southeast coast of India. Can. J. Microbiol. 2016, 62, 668-681. [CrossRef] [PubMed]

286. Ismail, A.; Ktari, L.; Ahmed, M.; Bolhuis, H.; Boudabbous, A.; Stal, L.J.; Cretoiu, M.S.; El Bour, M. Antimicrobial activities of bacteria associated with the brown alga Padina pavonica. Front. Microbiol. 2016, 7, 1072. [CrossRef]

287. Chakraborty, K.; Thilakan, B.; Raola, V.K. Polyketide family of novel antibacterial 7-O-methyl-5'-hydroxy-3'-heptenoatemacrolactin from seaweed-associated Bacillus subtilis MTCC 10403. J. Agric. Food Chem. 2014, 62, 12194-12208. [CrossRef]

288. Jamal, M.T.; Morris, P.C.; Hansen, R.; Jamieson, D.J.; Burgess, J.G.; Austin, B. Recovery and characterization of a 30.7-kDa protein from Bacillus licheniformis associated with inhibitory activity against methicillin-resistant Staphylococcus aureus, vancomycinresistant Enterococci, and Listeria monocytogenes. Mar. Biotechnol. 2006, 8, 587-592. [CrossRef] 
289. Cristianawati, O.; Sibero, M.T.; Ayuningrum, D.; Nuryadi, H.; Syafitri, E.; Riniarsih, I.; Radjasa, O.K. Screening of antibacterial activity of seagrass-associated bacteria from the North Java Sea, Indonesia against multidrug-resistant bacteria. Aquac. Aquar. Conserv. Legislat. 2019, 12, 1054-1064.

290. Ravikumar, S.; Thajuddin, N.; Suganthi, P.; Jacob Inbaneson, S.; Vinodkumar, T. Bioactive potential of seagrass bacteria against human bacterial pathogens. J. Environ. Biol. 2010, 31, 387.

291. Bodhaguru, M.; Prakash, S.; Ramasubburayan, R.; Ahila, N.K.; Mariselvam, L.; Immanuel, G.; Palavesam, A.; Kannapiran, E. Screening, partial purification of antivibriosis metabolite sterol-glycosides from Rhodococcus sp. against aquaculture associated pathogens. Microb. Pathog. 2019, 134, 103597. [CrossRef]

292. Bibi, F.; Ullah, I.; Alvi, S.; Bakhsh, S.; Yasir, M.; Al-Ghamdi, A.; Azhar, E. Isolation, diversity, and biotechnological potential of rhizo-and endophytic bacteria associated with mangrove plants from Saudi Arabia. Genet. Mol. Res. 2017, 16, gmr16029657. [CrossRef]

293. Balakrishnan, B.; Ranishree, J.K.; Thadikamala, S.; Panchatcharam, P. Purification, characterization and production optimization of a vibriocin produced by mangrove associated Vibrio parahaemolyticus. Asian Pac. J. Trop. Biomed. 2014, 4, 253-261. [CrossRef]

294. Bhadury, P.; Mohammad, B.T.; Wright, P.C. The current status of natural products from marine fungi and their potential as anti-infective agents. J. Ind. Microbiol. Biotechnol. 2006, 33, 325. [CrossRef] [PubMed]

295. Jensen, P.R. Natural products and the gene cluster revolution. Trends Microbiol. 2016, 24, 968-977. [CrossRef] [PubMed]

296. Chiang, Y.-M.; Chang, S.-L.; Oakley, B.R.; Wang, C.C. Recent advances in awakening silent biosynthetic gene clusters and linking orphan clusters to natural products in microorganisms. Curr. Opin. Chem. Biol. 2011, 15, 137-143. [CrossRef]

297. Konstantinou, D.; Mavrogonatou, E.; Zervou, S.-K.; Giannogonas, P.; Gkelis, S. Bioprospecting sponge-associated marine Cyanobacteria to produce bioactive compounds. Toxins 2020, 12, 73. [CrossRef] [PubMed]

298. Graça, A.P.; Calisto, R.; Lage, O.M. Planctomycetes as novel source of bioactive molecules. Front. Microbiol. 2016, 7, 1241. [CrossRef] [PubMed]

299. Wade, W. Unculturable bacteria-The uncharacterized organisms that cause oral infections. J. R. Soc. Med. 2002, 95, 81-83. [PubMed]

300. Vartoukian, S.R.; Palmer, R.M.; Wade, W.G. Strategies for culture of 'unculturable'bacteria. FEMS Microbiol. Lett. 2010, 309, 1-7. [PubMed]

301. Zeaiter, Z.; Mapelli, F.; Crotti, E.; Borin, S. Methods for the genetic manipulation of marine bacteria. Electron. J. Biotechnol. 2018, 33, 17-28. [CrossRef]

302. Trindade, M.; Van Zyl, L.J.; Navarro-Fernández, J.; Abd Elrazak, A. Targeted metagenomics as a tool to tap into marine natural product diversity for the discovery and production of drug candidates. Front. Microbiol. 2015, 6, 890. [CrossRef] [PubMed]

303. Mahapatra, G.P.; Raman, S.; Nayak, S.; Gouda, S.; Das, G.; Patra, J.K. Metagenomics approaches in discovery and development of new bioactive compounds from marine actinomycetes. Curr. Microbiol. 2019, 77, 645-656. [CrossRef]

304. Olano, C.; García, I.; González, A.; Rodriguez, M.; Rozas, D.; Rubio, J.; Sánchez-Hidalgo, M.; Braña, A.F.; Méndez, C.; Salas, J.A. Activation and identification of five clusters for secondary metabolites in Streptomyces albus J 1074. Microb. Biotechnol. 2014, 7, 242-256. [CrossRef] [PubMed] 